INSTITUTO DE PESQUISAS ENERGÉTICAS E NUCLEARES

Autarquia Associada à Universidade de São Paulo

\title{
MECANISMOS ASSOCIADOS AO REFINO DE GRÃO EM LIGAS DE ALUMÍNIO APÓS PROCESSAMENTO PELA TÉCNICA DE PRENSAGEM EM CANAIS EQUIANGULARES (PCE)
}

\section{ISÁC ALMEIDA DA SILVA}

\author{
Tese apresentada como parte dos \\ requisitos para a obtenção do Grau de \\ Doutor na Área de Ciências em \\ Tecnologia Nuclear - Aplicações.
}

Orientador

Prof. Dr. Waldemar Alfredo Monteiro

São Paulo 
INSTITUTO DE PESQUISAS ENERGÉTICAS E NUCLEARES Autarquia Associada à Universidade de São Paulo

\title{
MECANISMOS ASSOCIADOS AO REFINO DE GRÃO EM LIGAS DE ALUMÍNIO APÓS PROCESSAMENTO PELA TÉCNICA DE PRENSAGEM EM CANAIS EQUIANGULARES (PCE)
}

\author{
Versão Corrigida \\ Versão Original disponível no IPEN
}

ISÁC ALMEIDA DA SILVA

Tese apresentada como parte dos requisitos para a obtenção do Grau de Doutor na Área de Ciências em Tecnologia Nuclear - Aplicações.

Orientador

Prof. Dr. Waldemar Alfredo Monteiro

São Paulo

2020 
Autorizo a reprodução e divulgação total ou parcial deste trabalho, para fins de estudo e pesquisa, desde que citada a fonte

Como citar:

SILVA, I. A. D. MECANISMOS ASSOCIADOS AO REFINO DE GRÃO EM LIGAS DE ALUMÍNIO APÓS PROCESSAMENTO PELA TÉCNICA DE PRENSAGEM EM CANAIS EQUIANGULARES (PCE). 2020. 117p. Tese (Doutorado em Tecnologia Nuclear), Instituto de Pesquisas Energéticas e Nucleares, IPEN-CNEN/SP, São Paulo. Disponível em: (data de consulta no formato: $d d / \mathrm{mm} /$ aaaa)

Ficha catalográfica elaborada pelo Sistema de geração automática da Biblioteca IPEN/USP, com os dados fornecidos pelo(a) autor(a)

SILVA, ISAC ALMEIDA DA MECANISMOS ASSOCIADOS AO REFINO DE GRÃO EM LIGAS DE ALUMÍNIO APÓS PROCESSAMENTO PELA TÉCNICA DE PRENSAGEM EM CANAIS EQUIANGULARES (PCE)/ ISAC ALMEIDA DA SILVA, orientador WALDEMAR ALFREDO MONTEIRO. -- São Paulo, 2020. $117 \mathrm{p}$.

TESE (Doutorado) - Programa de Pós-Graduação em Tecnologia Nuclear (Materiais) -- Instituto de Pesquisas Energéticas e Nucleares, São Paulo, 2020.

1. Liga de AA 3003. 2. RECRISTALIZAÇÃO NÃO-FERROSOS. 3. DEFORMAÇÃO PLÁSTICA INTERNA. 4. PRENSAGEM CANAIS EQUIANGULARES. 5. ECAP. I. MONTEIRO, WALDEMAR ALFREDO, , orient. II. Título. 
Dedico este trabalho a Deus, a minha mãe e a minha família. 


\section{AGRADECIMENTOS}

A Deus, profundo conhecedor dos desejos de meu coração, que me faz trilhar por veredas de vales escuros, mas as clareia tal qual o caminho dos justos que, como a luz da aurora, vai brilhando, brilhando, até ser dia perfeito.

A minha mãe Dulcinéia Almeida da Silva que me tomou pela mão e me ensinou que o caminho estreito é o mais difícil de trilhar, mas é o que leva à mais saborosa vitória.

Ao meu orientador professor doutor Waldemar Alfredo Monteiro, mensageiro enviado de Deus, sem o qual não existiria este trabalho.

A minha esposa, doutora Laodicéia Monteiro Almeida da Silva pela paciência, constante oração em meu favor e apoio incondicional.

A minha filha Isabelle Stéphanie Brown Monteiro Almeida pelo auxílio técnico constante e incansável. Pelas palavras de carinho e ânimo nos momentos aflitivos.

Ao meu filho Victor Lion Brown Monteiro Almeida, meu fiel companheiro degustador de ervas amargosas da vida, pelo carinho, humor de gente feliz e sorriso sincero, puros combustíveis para mim nesta empreitada.

A minha irmã professora doutora Eunice Almeida da Silva, USP, pelo companheirismo e incentivo com a própria carreira universitária exemplar.

Ao laboratorista da CBA Alexandro Rafael de Andrade, pela disposição constante, sem jamais me deixar esperando resposta.

Aos mestres do laboratório de engenharia de materiais Abner Cabral Neto, Maria Lioba Crespo (Liuba) e Rogério Aparecido Lopes da Silva pela disposição de me acompanhar na execução dos diversos ensaios.

A Leonardo Zappi, que de forma generosa, em tempos excepcionais, realizou medições de condutividade nos corpos de prova diminutos apresentados. 
“... para que se torne conhecida a multiforme sabedoria de Deus, que tudo criou."

Efésios cap.3 vers.9,10 


\title{
MECANISMOS ASSOCIADOS AO REFINO DE GRÃO EM LIGAS DE ALUMÍNIO APÓS PROCESSAMENTO PELA TÉCNICA DE PRENSAGEM EM CANAIS EQUIANGULARES (PCE)
}

\author{
Isác Almeida da Silva
}

\begin{abstract}
RESUMO
A aplicação final dos materiais metálicos depende das propriedades físicas e mecânicas destes, que podem ser adquiridas por diversos mecanismos aos quais eles são submetidos. Uma propriedade que não raras vezes tem se tornado muito importante e decisiva na utilização dos metais é o tamanho médio de grão do material. Devido ao fato dos materiais metálicos com tamanho de grão muitíssimo pequeno, de ordem submicrométrica, ou nanométrica, apresentarem significativo aumento de resistência mecânica, a sua fabricação tem sido de interesse crescente. Entretanto, a prática industrial convencional para produzir apurado refinamento de grãos em materiais metálicos massivos é o processamento termomecânico, pelo qual, os menores tamanhos de grão obtidos são de ordem micrométrica, mas não submicrométrica ou a nanométrica. São apresentados neste trabalho os mecanismos associados ao refino de grão nas ligas de alumínio AA 1050 e AA 3003 após processamento pela técnica de Prensagem em Canais Equiangulares (PCE), que, por Deformação Plástica Intensa (DPI) bloqueará o movimento das discordâncias do material, conferindo-Ihe alta resistência, boa tenacidade e grãos de tamanho nanométrico. Este bloqueio pode também ser obtido por encruamento, solução sólida e precipitação de solutos, porém, os métodos de refinamento de grãos em metais e ligas estão inseridos dentre os mais significativos avanços em metalurgia física.
\end{abstract}

Palavras chave: Liga de Alumínio 1050; liga de Alumínio 3003; prensagem em canais equiangulares; deformação plástica intensa; recristalização de não ferrosos. 


\title{
GRAIN REFINING IN ALUMINUM ALLOYS AFTER PROCESSING BY EQUAL CHANNEL ANGULAR PRESSING TECHNIQUES (ECAP) - ASSOCIATED MECHANISMS
}

\author{
Isác Almeida da Silva
}

\begin{abstract}
The final application of metallic materials depends on their physical and mechanical properties, which can be acquired by various mechanisms to which they are subjected. A property that has often become very important and decisive in the use of metals is the average grain size of the material. Due to the fact that metallic materials with a very small grain size, submicrometric, or nanometric, present a significant increase in mechanical resistance, their manufacture has been of increasing interest. However, the conventional industrial practice for producing refined grain refinement in massive metallic materials is thermomechanical processing, whereby the smallest grain sizes obtained are micrometric, but not submicrometric or nanometric. This research presents the mechanisms associated with grain refining in aluminum alloys $A A 1050$ and $A A$ 3003 after processing by the Pressing Technique in Equiangular Channels (PCE), which, by Intense Plastic Deformation (DPI) will block the movement of material discrepancies, giving it high strength, good toughness and nanometer-sized grains. This blockage can also be obtained by hardening, solid solution and precipitation of solutes, however, the methods of grain refinement in metals and alloys are inserted among the most significant advances in physical metallurgy.
\end{abstract}

Keywords: Aluminum alloy 1050; Aluminum alloy 3003; processing by equal channel angular pressing; intense plastic deformation; non-ferrous recrystallization. 


\section{SUMÁRIO}

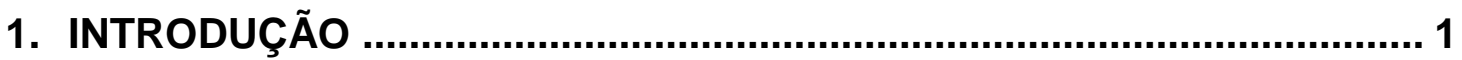

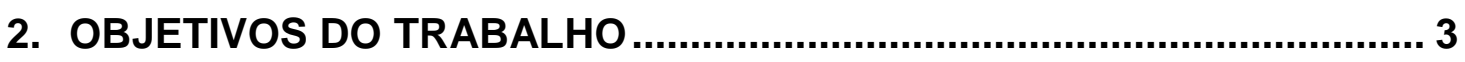

2.1. Objetivo Geral ............................................................. 3

2.2. Objetivos específicos ………………………….............. 3

3. REVISÃO DA LITERATURA.............................................................. 4

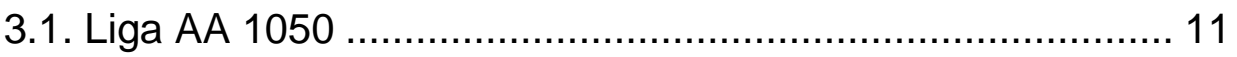

3.2. Liga AA 3003 (Al-Mn) ................................................ 12

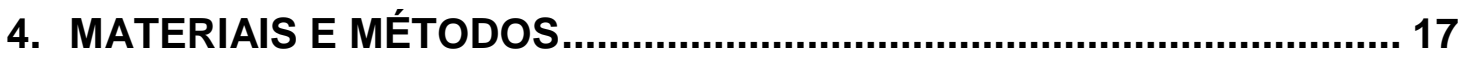

4.1. Preparativo das Amostras ............................................... 17

4.2. Tratamentos Térmicos …….............................................. 20

4.3. Caracterização Microestrutural, Mecânica e Elétrica após tratamentos térmicos.......................................................... 20

4.4. Prensagem por Canais Equiangulares (PCE) .................... 21

4.5. Caracterização Microestrutural, Mecânica e Elétrica após prensagem por Canais Equiangulares (PCE) ........................... 25

5. RESULTADOS E DISCUSSÕES

5.1. Liga de Alumínio AA 3003.

5.1.1. Caracterização Microestrutural e Mecânica do material como recebido 
5.1.1.1. Microscopia Óptica (MO)

5.1.1.2. Espectro de Dispersão de energia (EDS) - Microscópio Eletrônico de Varredura (MEV) 28

5.1.1.3. Determinação da Condutividade Elétrica $(\sigma)$ 30

5.1.2. Caracterização Microestrutural e Mecânica do Material após Tratamento Térmico Inicial ( $500^{\circ} \mathrm{C}-8 \mathrm{~h}$ ), pré PCE 31

5.1.2.1. Microscopia Óptica (MO) com luz polarizada do material, pós Tratamento Térmico Incial ( $500 \stackrel{\circ}{\circ}-8 \mathrm{~h}$ ), pré PCE 32

5.1.3. Caracterização Microestrutural e Mecânica do Material após Prensagem por Canais Equiangulares (PCE) 33

5.1.3.1. Microscopia Óptica (MO) cim luz polarizada. 33

5.1.3.1.1. Micrografias das amostras da liga AA 3003 prensadas pela rota $A$ - pré e pós cozimento 33

5.1.3.1.2. Micrografias das amostras da liga AA 3003 prensadas pela rota $\mathrm{Bc}$ - pré e pós cozimento 38

5.1.3.2. Determinação do Tamanho de Grão do material da liga AA 3003 43

5.1.3.3. Determinação de Microdureza Vickers (HV) pós Prensagem por Canais Equiangulares (pré recozimento e pós recozimento) do material da liga AA 3003 44

5.1.3.4. Determinação da Condutividade Elétrica $(\sigma)$ 45

5.1.4. Caracterização Microestrutural, Mecânica e Elétrica do Material - pós Prensagem por Canais Equiangulares (PCE) pós Tratamento Térmico Posterior $\left(300^{\circ} \mathrm{C}-2,0 \mathrm{~h}\right) \ldots \ldots \ldots \ldots \ldots . . . . . .46$

5.1.4.1. Microscopia Óptica (MO) .......................................... 46

5.1.4.2. Determinação de Microdureza Vickers (HV) ............... 49

5.1.4.3. Determinação da Condutividade Elétrica $(\sigma)$.............. 50 
5.2. Liga de Alumínio AA 1050.

5.2.1. Caracterização Microestrutural, Mecânica e Elétrica do material como recebido 51

5.2.1.1. Microscopia Óptica (MO) 53

5.2.1.2. Microscopia Eletrônica de Varredura (MEV) - Espectro de Dispersão de Energia (EDS) 54

5.2.2 Caracterização Microestrutural, Macânica e Elétrica do Material da liga AA 1050 pós Tratamento Térmico Inicial (400 $\cong$ C $-30 \mathrm{~min}$ ), pré PCE 55

5.2.2.1. Microscopia Óptica (MO) 55

5.2.2.2. Microscopia Eletrônica de Transmissão (MET) 59

5.2.2.3. Determinação de Microdureza Vickers (HV) 60

5.2.2.4. Determinação da Condutividade Elétrica $(\sigma)$ 61

5.2.3. Caracterização Microestrutural, Mecânica e Elétrica do material da liga AA 1050, pós Prensagem por Canais Equiangulares - PCE, pré Tratamentos Térmicos Posteriores. 62 5.2.3.1. Microscopia Óptica (MO) 62

5.2.3.1.1. Micrografias das Amostras Prensadas pela rota A ... 62 5.2.3.1.2. Micrografias das Amostras Prensadas pela rota Bc . 66 5.2.3.2. Determinação de Microdureza Vickers (HV) após Prensagem por Canais Equiangulares (PCE) 68

5.2.3.3. Determinação da Resistência, Resistividade e

Condutividade Elétrica $(\sigma)$ do material das amostras submetidas à PCE - liga AA 1050 69

5.2.4. Caracterização Microestrutural, Mecânica e Elétrica do material da liga AA 1050, pós PCE, pós Tratamentos Térmicos Posteriores...

5.2.4.1. Microscopia Óptica (MO) 70

5.2.4.1.1. Micrografias das Amostras Prensadas pela rota A ... 71 
5.2.4.1.2. Micrografias das Amostras Prensadas pela rota Bc 76

5.2.4.2. Microscopia Eletrônica de Transmissão (MET) 81

5.2.4.2.1. Micrografias das Amostras Prensadas pela rota A ... 81

5.2.4.2.2. Micrografias das Amostras Prensadas pela rota BC. 83

5.2.4.3. Determinação da Microdureza Vickers (HV) 84

6. CONCLUSÕES 86 


\section{LISTA DE FIGURAS}

\section{Figura 01 - Página 6}

Processamento por Canais Equiangulares:

(a) Esquema do Processamento Mecânico por Canalização Angular Equivalente (PCE) ou Equal Channel Angular Processing (ECAP); (b) Elemento de transformação em cisalhamento simples; (c) Representação esquemática da distorção experimental da peça como uma grade sincronizada.

\section{Figura 02 - Página 7}

Rotas de processamento por PCE (SILVA 2013).

\section{Figura 03 - Página 15}

Diagrama de fases da liga Al-Mn (McAlister and Murray, 1987).

\section{Figura 04 - Página 17}

Exemplares dos corpos de prova obtidos pelo método de laminação a quente. a) Liga AA 3003; b) Liga AA 1050.

\section{Figura 05 - Página 18}

Fluxograma das etapas de procedimentos - Liga de Alumínio AA 1050.

\section{Figura 06 - Página 19}

Fluxograma das etapas de procedimentos - Liga de Alumínio AA 3003

Figura 07 - Página 22

Máquina de Ensaio Universal Test - ZD 100 PU - (UPM).

\section{Figura 08 - Página 22}

Máquina de Ensaio Universal com matriz e punção.

\section{Figura 09 - Página 23}

Punção, acessório da matriz usada na PCE: a) vista de perfil; b) vista inclinada de topo. 


\section{Figura 10 - Página 23}

Matriz utilizada na técnica PCE.

\section{Figura 11 - Página 24}

Resumo de distribuição das amostras para PCE - Liga AA 1050.

\section{Figura 12 - Página 25}

Resumo de distribuição das amostras para PCE - Liga AA 3003.

\section{Figura 13 - Página 26}

Esquema das etapas de caracterização da liga .AA 3003 após PCE.

\section{Figura 14 - Página 27}

Sentido de extrusão das placas metálicas das ligas de alumínio AA 1050 e AA 3003 cedidas pela CBA. (GUERRA, 2015).

\section{Figura 15 - Página 28}

Micrografia da secção longitudinal MO (500X - secção long. - meio) da liga AA 3003 (situação inicial) - material como recebido. Microdureza $=(38 \pm 1) \mathrm{HV}$.

\section{Figura 16 - Página 29}

MEV - EDS - Espectro de dispersão de energia para a liga AA 3003

\section{Figura 17 - Página 32}

MO - micrografia com luz polarizada (longitudinal - 50X) da liga AA 3003, pós tratamento térmico inicial (500 ${ }^{\circ} \mathrm{C}-8,0 \mathrm{~h}$, após rampa de $3,0 \mathrm{~h}$ ) Pré PCE. Microdureza $=(32 \pm 1) \mathrm{HV}$.

\section{Figura 18 - Página 34}

MO -- Micrografia com luz polarizada (longitudinal - 500X) da liga AA 3003: (a) rota $A-\mathbf{1 A}$, pré recozimento; (b) rota $A-\mathbf{1 A}$, pós recozimento. 
MO - micrografia com luz polarizada (longitudinal - 500X) da liga AA 3003: (a) rota $A-2 A$, pré recozimento; (b) rota $A-2 A$, pós recozimento.

\section{Figura 20 - Página 36}

MO - micrografia com luz polarizada (longitudinal - 500X) da liga AA 3003: (a) rota $\mathrm{A}-\mathbf{3 A}$, pré recozimento; (b) rota $\mathrm{A}-\mathbf{3 A}$, pós recozimento.

\section{Figura 21 - Página 37}

MO - micrografia com luz polarizada (longitudinal - 500X) da liga AA 3003: (a) rota $A-4 A$, pré recozimento; (b) rota $A-4 A$, pós recozimento.

\section{Figura 22 - Página 39}

MO - micrografia com luz polarizada (longitudinal - 500X) da liga AA 3003: (a) rota $\mathrm{Bc}-1 \mathrm{Bc}$, pré recozimento; (b) rota $\mathrm{Bc}-\mathbf{1 B c}$, pós recozimento.

\section{Figura 23 - Página 40}

MO - micrografia com luz polarizada (longitudinal - 500X - liga AA 3003: (a) rota $\mathrm{Bc}-\mathbf{2} \mathrm{Bc}$, pré recozimento; (b) rota $\mathrm{Bc}-\mathbf{2} \mathrm{Bc}$, pós recozimento.

\section{Figura 24 - Página 41}

MO - micrografia com luz polarizada (longitudinal - 500X - liga AA 3003: (a) rota $\mathrm{Bc}-4 \mathrm{Bc}$, pré recozimento; (b) rota $\mathrm{Bc}-4 \mathrm{Bc}$, pós recozimento.

\section{Figura 25 - Página 47}

MO - micrografia com luz polarizada (longitudinal - 500X - liga AA 3003: rota $A$ - 4A, pós PCE, pós tratamento térmico posterior (300 ${ }^{\circ} \mathrm{C}-2,0$ horas). Com 0 sentido da extrusão.

\section{Figura 26 - Página 48}

MO - micrografia com luz polarizada (longitudinal - 500X - liga AA 3003: rota Bc - 4Bc, pós PCE, pós tratamento térmico posterior (300 ${ }^{\circ} \mathrm{C}-2,0$ horas). Com 0 sentido da extrusão. 


\section{Figura 27 - Página 52}

Micrografias da secção longitudinal da liga AA 1050 - material como recebido: (a) aumento 50X; (b) aumento 100X, com o sentido da extrusão; (c) aumento 200X.

\section{Figura 28 - Página 53}

Micrografias da secção transversal da liga AA 1050 - material como recebido: (a) aumento 50X; (b) aumento 100X, com o sentido da extrusão; (c) aumento 200X.

\section{Figura 29 - Página 54}

Espectro de dispersão de energia (EDS) para a liga de alumínio AA 1050 Material como recebido

\section{Figura 30 - Página 56}

Micrografias da secção normal da liga AA 1050 - pós tratamento térmico inicial, pré PCE: (a) aumento 100X; (b) aumento 200X; (c) aumento 300X.

\section{Figura 31 - Página 57}

Micrografias da secção longitudinal da liga AA 1050 - pós tratamento térmico inicial, pré PCE: (a) aumento 100X; (b) aumento 200X; (c) aumento 300X.

\section{Figura 32 - Página 58}

Micrografias da secção transversal da liga AA 1050 - pós tratamento térmico inicial, pré PCE: (a) aumento 100X; (b) aumento 200X; (c) aumento 300X.

\section{Figura 33 - Página 59}

MET - Micrografias eletrônicas de transmissão da secção transversal da liga AA 1050 - pós tratamento térmico inicial, pré PCE: após tratamento inicial ( $400 \stackrel{\circ}{\circ}$ $30 \mathrm{~min}$ ) - pré PCE.

\section{Figura 34 - Página 63}

Micrografias da secção normal da liga AA 1050 - pós prensagem por canais equiangulares - PCE (4 passes - rota A): (a) aumento 50X; (b) aumento 100X; (c) aumento 200X, com a indicação do sentido de extrusão. 


\section{Figura 35 - Página 64}

Micrografias da secção longitudinal da liga AA 1050 - pós prensagem por canais eqangulares - PCE (4 passes - rota A): (a) aumento 50X; (b) aumento 100X; (c) aumento 200X, com a indicação do sentido de extrusão.

\section{Figura 36 - Página 65}

Micrografias da secção transversal da liga AA 1050 - pós prensagem por canais eqangulares - PCE (4 passes - rota A): (a) aumento 50X; (b) aumento 100X; (c) aumento 200X, com a indicação do sentido de extrusão.

\section{Figura 37 - Página 66}

Micrografias da secção longitudinal da liga AA 1050 - pós prensagem por canais equiangulares - PCE (4 passes - rota Bc): (a) aumento 50X; (b) aumento 100X, com a indicação do sentido de extrusão.

\section{Figura 38 - Página 67}

Micrografias da secção transversal da liga AA 1050 - pós prensagem por canais equiangulares - PCE (4 passes - rota Bc): (a) aumento 50X; (b) aumento 100X, com a indicação do sentido de extrusão.

\section{Figura 39 - Página 71}

Micrografias da secção normal da liga AA 1050 - pós PCE - rota A - pós envelhecimento (250 ำ - 30 minutos): (a) aumento 50X, com a indicação do sentido de extrusão; (b) aumento 100X; (c) aumento 200X.

\section{Figura 40 - Página 72}

Micrografias da secção normal da liga AA 1050 - pós PCE - rota A - pós envelhecimento (250 ${ }^{\circ} \mathrm{C}-30$ minutos): (a) aumento $50 \mathrm{X}$, com a indicação do sentido de extrusão; (b) aumento 100X; (c) aumento 200X.

\section{Figura 41 - Página 73}

Micrografias da secção normal da liga AA 1050 - pós PCE - rota A - pós envelhecimento (250 ${ }^{\circ} \mathrm{C}-60$ minutos): (a) aumento $50 \mathrm{X}$, com a indicação do sentido de extrusão; (b) aumento 100X. 


\section{Figura 42 - Página 73}

Micrografias da secção transversal da liga AA 1050 - pós PCE - rota A - pós envelhecimento (250 ${ }^{\circ} \mathrm{C}-60$ minutos): (a) aumento $50 \mathrm{X}$, com a indicação do sentido de extrusão; (b) aumento 100X.

\section{Figura 43 - Página 74}

Micrografias da secção longitudinal da liga AA 1050 - pós PCE - rota A - pós envelhecimento (250 ${ }^{\circ} \mathrm{C}-90$ minutos): (a) aumento $50 \mathrm{X}$, com a indicação do sentido de extrusão; (b) aumento 100X.

\section{Figura 44 - Página 74}

Micrografias da secção transversal da liga AA 1050 - pós PCE - rota A - pós envelhecimento (250 $\stackrel{\circ}{C}-90$ minutos): (a) aumento $50 \mathrm{X}$, com a indicação do sentido de extrusão; (b) aumento 100X.

\section{Figura 45 - Página 75}

Micrografias da secção normal da liga AA 1050 - pós PCE - rota A - pós envelhecimento ( $250^{\circ} \mathrm{C}-120$ minutos): (a) aumento $50 \mathrm{X}$; (b) aumento $200 \mathrm{X}$, com a indicação do sentido de extrusão.

\section{Figura 46 - Página 75}

Micrografias da secção longitudinal da liga AA 1050 - pós PCE - rota $A$ - pós envelhecimento (250 ${ }^{\circ} \mathrm{C}-120$ minutos): (a) aumento $50 \mathrm{X}$; (b) aumento $100 \mathrm{X}$, com a indicação do sentido de extrusão.

\section{Figura 47 - Página 76}

Micrografias da secção normal da liga AA 1050 - pós PCE - rota Bc - pós envelhecimento (250 ำ - 30 minutos): (a) aumento 50X; (b) aumento 100X, com a indicação do sentido de extrusão.

\section{Figura 48 - Página 76}

Micrografias da secção longitudinal da liga AA 1050 - pós PCE - rota Bc - pós envelhecimento (250 ${ }^{\circ} \mathrm{C}-30$ minutos): (a) aumento $50 \mathrm{X}$, com a indicação do sentido de extrusão; (b) aumento 100X. 


\section{Figura 49 - Página 77}

Micrografias da secção normal da liga AA 1050 - pós PCE - rota Bc - pós envelhecimento ( $250^{\circ} \mathrm{C}-60$ minutos): (a) aumento 50X; (b) aumento 100X, com a indicação do sentido de extrusão.

\section{Figura 50 - Página 77}

Micrografias da secção longitudinal da liga AA 1050 - pós PCE - rota Bc - pós envelhecimento ( $250 \stackrel{\circ}{\circ}-60$ minutos): (a) aumento 50X; (b) aumento 100X, com a indicação do sentido de extrusão.

\section{Figura 51 - Página 78}

Micrografias da secção normal da liga AA 1050 - pós PCE - rota $\mathrm{Bc}$ - pós envelhecimento ( $250 \stackrel{\circ}{\circ}-90$ minutos): (a) aumento 50X; (b) aumento 100X, com a indicação do sentido de extrusão.

\section{Figura 52 - Página 78}

Micrografias da secção longitudinal da liga AA 1050 - pós PCE - rota Bc - pós envelhecimento (250 ${ }^{\circ} \mathrm{C}-90$ minutos): (a) aumento $50 \mathrm{X}$, com a indicação do sentido de extrusão; (b) aumento 100X.

\section{Figura 53 - Página 79}

Micrografias da secção normal da liga AA 1050 - pós PCE - rota Bc - pós envelhecimento (250 ${ }^{\circ} \mathrm{C}-120$ minutos): (a) aumento $50 \mathrm{X}$, com a indicação do sentido de extrusão; (b) aumento 100X; (c) aumento 200X.

\section{Figura 54 - Página 80}

Micrografias da secção longitudinal da liga AA 1050 - pós PCE - rota Bc - pós envelhecimento ( $250 \stackrel{\circ}{\circ}-120$ minutos): (a) aumento $50 \mathrm{X}$, com a indicação do sentido de extrusão; (b) aumento 100X.

\section{Figura 55 - Página 80}

Micrografias da secção trransversal da liga AA 1050 - pós PCE - rota Bc - pós envelhecimento (250 ${ }^{\circ} \mathrm{C}-120$ minutos): (a) aumento $50 \mathrm{X}$, com a indicação do sentido de extrusão; (b) aumento 100X. 


\section{Figura 57/56A - Página 82}

Micrografias eletrônicas de transmissão da secção transversal da liga AA 1050 pós PCE - rota $\mathrm{A}$ - pós envelhecimento ( $250^{\circ} \mathrm{C}-120$ minutos).

\section{Figura 57/57 A - Página 83}

Micrografias eletrônicas de transmissão da secção transversal da liga AA 1050 pós $\mathrm{PCE}$ - rota $\mathrm{Bc}$ - pós envelhecimento ( $250 \stackrel{\circ}{\circ}-120$ minutos). 


\section{LISTA DE TABELAS}

Tabela 1 - Página 11

Composição química das ligas de alumínio AA 1050 e AA 3003.

\section{Tabela 2 - Página 33}

Condutividade Elétrica do material da liga AA 3003, como recebido.

\section{Tabela 3 - Página 44}

Comparação das micrografias com luz polarizada das rotas A e Bc.

\section{Tabela 4 - Página 45}

Diâmetros médios dos grãos da liga AA 3003 obtidos pelo método de Heyn.

\section{Tabela 5 - Página 47}

Microdureza Vickers pós processo PCE (pré recozimento e pós recozimento).

\section{Tabela 6 - Página 48}

Condutividade Elétrica do material da liga AA 3003, pós prensagem e pós recozimento $(500 \stackrel{\circ}{C}-1,0$ hora).

\section{Tabela 7 - Página 52}

Microdureza do material da liga AA 3003 pré e pós tratamento térmico posterior (300 $\stackrel{\circ}{C}-2,0$ horas)

\section{Tabela 8 - Página 53}

Condutividade Elétrica do material da liga AA 3003, pós prensagem e pós tratamento térmico posterior ( $300 \stackrel{\circ}{ } \mathrm{C}-2,0$ horas).

\section{Tabela 9 - Página 62}

Microdureza Vickers (HV) - Liga AA 1050 - após tratamento térmico inicial (400 ${ }^{\circ} \mathrm{C}-30$ minutos), pré prensagem por canais equiangulares - Carga de $300 \mathrm{~g}$. 


\section{Tabela 10 - Página 63}

Resistência, Resistividade e Condutividade elétricas do material da liga AA 1050, pós tratamento térmico inicial ( $400 \stackrel{\circ}{\circ}-30$ minutos), pré prensagem por canais equiangulares.

\section{Tabela 11 - Página 70}

Microdureza Vickers (HV) - Liga AA 1050 - pré prensagem por canais equiangulares - PCE e pós prensagem por canais equiangulares, (rota $A$ e rota Bc). Carga de $300 \mathrm{~g}$.

\section{Tabela 12 - Página 71}

Resistência, Resistividade e Condutividade elétricas d material da liga AA 1050, antes da PCE e pós PCE (rotas A e rota Bc).

\section{Tabela 13 - Página 87}

Microdureza Vickers (HV) - Liga AA 1050 - pós envelhecimento (250 ํㅡ-tempos diversos. Carga de $300 \mathrm{~g}$. 


\section{LISTA DE ABREVIATURAS}

AA

ABAL

CBA

CCC

CFC

EBSD

ECAP

UFE

DPI

HC

HV

IACS

MET

MEV

MO

PCE

UPM
Aluminum Association

Associação Brasileira do Alumínio

Companhia Brasileira do Alumínio

Cúbico de Corpo Centrado

Cúbico de Face Centrada

Electron BackScatter Diffraction

Equal Channel Angular Pressing

Ultra Finamentee Estruturado

Deformação Plástica Intensa

Hexagonal Compacta

Heardness Vickers

International Annealed Copper Standard

Mcroscopia Eletrônica de Transmissão

Microscopia Eletrônica de Varredura

Microscopia Óptica

Prensagem por Canais Equiangulares

Universidade Presbiteriana Mackenzie 


\section{INTRODUÇÃO}

A excepcional combinação de propriedades úteis do material metálico alumínio abre um enorme campo de aplicações deste metal na engenharia. Como o mais importante dos metais não ferrosos, o alumínio acompanha o ferro/aço entre os metais de maior aumento de consumo anual, o que Ihe dá significativa importância na indústria moderna. (ABAL, 2007). Dentre as características físico-químicas que promovem 0 alumínio às inúmeras utilizações estão sua resistência a corrosão, alta condutibilidade eletrotérmica e, sobretudo, o seu baixo peso específico, em relação aos outros materiais metálicos.

Com vistas na fabricação de materiais com elevados valores de resistência mecânica e tenacidade é que a engenharia tem buscado compreender melhor os mecanismos a que estes metais possam ser submetidos e assim indicar um novo caminho para a produção de materiais com propriedades atrativas para os segmentos aos quais são destinados. (SANTOS, 2008).

As propriedades físicas e mecânicas dos materiais metálicos podem ser adquiridas por diversos mecanismos aos quais eles são submetidos. Uma propriedade que não raras vezes tem se tornado muito importante e decisiva na utilização dos metais é o tamanho médio de grão do material. Devido ao fato de os materiais metálicos com tamanho de grão muitíssimo pequeno, de ordem submicrométrica, ou nanométrica apresentarem significativo aumento de resistência mecânica, a sua fabricação tem sido de interesse crescente. Entretanto, a prática industrial convencional para produzir apurado refinamento de grãos em materiais metálicos massivos é o processamento termomecânico, pelo qual, os menores tamanhos de grão obtidos são de ordem micrométrica, mas não submicrométrica ou nanométrica. O processamento de ligas metálicas através de prensagem em canais equiangulares (PCE) provoca a deformação plástica intensa (DPI) da liga, promovendo a criação de uma nova classe de materiais que tem uma combinação de propriedades benéficas, tal como ultra-alta estampabilidade, alta resistência mecânica, alta tenacidade e inclusive alta condutividade elétrica e térmica. A chave para a melhoria das propriedades é a 
criação da estrutura de grãos com tamanhos submicrométricos e nanométricos (KOCH, 2003; VALIEV, 2004).

Materiais finamente estruturados são policristais com tamanho de grão submicrométrico. O termo "material nanoestruturado" é usado para material de estrutura ultrafina com um tamanho de grão entre $10 \mathrm{~nm}$ e $100 \mathrm{~nm}$ e o termo "material submicroestruturado" para tamanhos de grão entre 100 nm e $1 \mu \mathrm{m}$. Em geral a ductilidade é diminuída quando a tensão de escoamento é aumentada em processamento mecânico. A prensagem por PCE, no entanto, permite produzir materiais metálicos que têm estrutura de grãos finos (menores que $1 \mu \mathrm{m}$ ) onde a tensão de escoamento é aumentada substancialmente, de acordo com a relação de Hall-Petch, sem perda da ductilidade.

São apresentados neste trabalho os mecanismos associados ao refino de grão da liga de alumínio AA 3003 e comparados com os da liga AA 1050, após ambas passarem pelo processamento da técnica de Prensagem em Canais Equiangulares (PCE), que, por Deformação Plástica Intensa (DPI) bloqueou o movimento das discordâncias do material, conferindo-lhe alta resistência, boa tenacidade e grãos de tamanho nanométrico. Este bloqueio poderia também ser obtido por encruamento, solução sólida e precipitação de solutos, porém, os métodos de refinamento de grãos em metais e ligas estão inseridos dentre os mais significativos avanços em metalurgia física. A contribuição original do trabalho reside no fato da pesquisa ter sido realizada sobre uma liga (AA 3003) que ainda não havia sido submetida à técnica PCE e que apresentou resultados superiores aos da utilizada liga AA 1050 e também melhores que os da prática industrial convencional, colocando-se como opção de vantagem comprovada na metalurgia física. 


\section{OBJETIVOS DO TRABALHO}

\subsection{Objetivo Geral}

Estudar o refino de grão em ligas de alumínio após processamento pela técnica de Prensagem em Canais Equiangulares (PCE) ou Deformação Plástica Intensa (DPI), com o registro dos mecanismos associados ao refino, tais como a identificação das rotas preferenciais e sua correlação com a evolução das estruturas ultrafinas obtidas e produção dos materiais metálicos ultra finamente estruturado (UFE), a partir de materiais na forma de pósmetálicos ou ligas metálicas massivas.

Obter, por deformação plástica intensa da liga de alumínio AA 3003, estrutura de grãos ultrafinos submicrométricos ou até nanométricos que possuam propriedades mecânicas especiais tais como significativa resistência mecânica e elevada tenacidade, ultra-alta estampabilidade, altas condutividades elétrica e térmica.

\subsection{Objetivos específicos}

2.2.1. Melhorar o ajuste da natureza da estrutura ultrafina obtida e sua influência em propriedades mecânicas.

2.2.2. Observar, escalonar e comparar os tratamentos térmicos adequados à melhor recristalização dos grãos das ligas de alumínio AA 3003 e AA 1050.

2.2.3. Realizar ensaios mecânicos, tais como, testes de microdureza Vickers (HV), ensaios microestruturais por microscopia óptica (MO) e microscopia eletrônica de varredura (MEV) e ensaios de condutividade elétrica, antes e após tratamentos térmicos em amostras previamente processadas por cisalhamento intenso (DPI). 


\section{REVISÃO DA LITERATURA}

Atualmente materiais processados em escala nanométrica têm demonstrado com frequência propriedades extraordinárias, tal como um decréscimo nos módulos elásticos, decréscimos das temperaturas de Curie e Debye, difusividade melhorada e melhoria das propriedades magnéticas (VALIEV 1991; KOCH 2003).

Com respeito às propriedades mecânicas, muitos experimentos têm revelado o potencial para alcançar alta resistência mecânica, resistência ao atrito, boa ductilidade em temperatura ambiente e superplasticidade a elevadas temperaturas. Um controle nanoestrutural em termos de propriedades ligadas ao contorno de grão tem permitido o desenvolvimento de novos materiais com combinações sem precedentes das propriedades mecânicas e conformação de superplasticidade (SEGAL 1981; GLEITER 1989; VALIEV 1991; MORRIS 1998; BOWEN 2000; KOCH 2003; VALIEV 2004).

O processo de deformação por cisalhamento puro consiste em fazer passar a amostra de um determinado material de uma extremidade à outra de dois canais sequenciais que se interceptam fazendo entre si, na matriz fabricada para o presente estudo, um ângulo de $120^{\circ}$. Neste processo não há alteração na secção transversal da amostra, portanto, a operação pode ser repetida várias vezes, permitindo obter graus de deformação muito altos em amostras metálicas. Justamente por não haver redução da secção transversal da amostra, ocorre um acúmulo de deformação plástica, que produz grãos com tamanhos na ordem de escala nanométrica.

Este processo foi proposto originalmente por Segal e colaboradores. Ele está sendo bastante estudado, tanto pelo seu aspecto prático (redução de tamanho de grão e consequente aumento de resistência mecânica e tenacidade) como pela exploração de diversos aspectos fundamentais de plasticidade, recristalização e formação de textura. (SEGAL, 2004)

Em processos convencionais de deformação plástica (laminação, compressão, trefilação, etc.) as dimensões da amostra são continuamente alteradas e, para se obter grandes deformações $(\varepsilon>4)$, o material resultante 
assume formato de chapas muito finas ou de filamentos que pode não ter aplicação tecnológica prática.

Existem vários métodos para causar deformações plásticas severas. Dentre esses métodos, a Prensagem em Canais Equiangulares (PCE), também chamada de Extrusão em Canal Angular (ECA), é um dos métodos mais simples de deformação, que em condições ideais ocorre por cisalhamento simples. Essa técnica tem como objetivo introduzir deformação plástica intensa em materiais sem alterar a seção transversal da amostra, sendo possível, portanto, repetir o processo várias vezes para aumentar o nível de deformação imposta, gerando deformações equivalentes da ordem de 10 a 15 (LANGDON 2000; BOWEN 2000; VALIEV 2000).

O princípio de extrusão por PCE está ilustrado esquematicamente na Figura 01. A matriz é um bloco com dois canais entrecortados e com idênticas secções transversais. Um tarugo metálico bem lubrificado de secção retangular ou quadrado que apresenta mesma secção transversal da ferramenta é colocado em um dos canais e um punção o empurra para o segundo canal, conforme ilustra a Figura 01(a). O material sob esta condição mover-se dentro dos canais como um corpo rígido e a deformação é realizada por cisalhamento simples, segundo a Figura 01(b). Assim, todo o tarugo (exceto pequenas regiões nas duas extremidades) é deformado em maneira bem uniforme, conforme observado na Figura 01(c). 


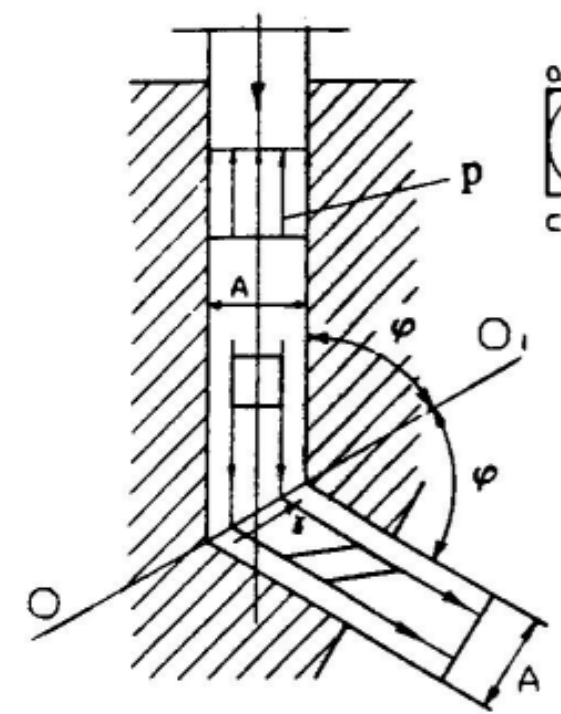

(d)

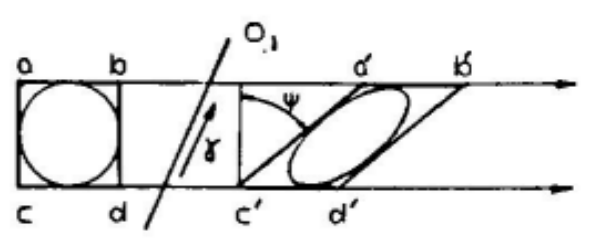

(b) 0

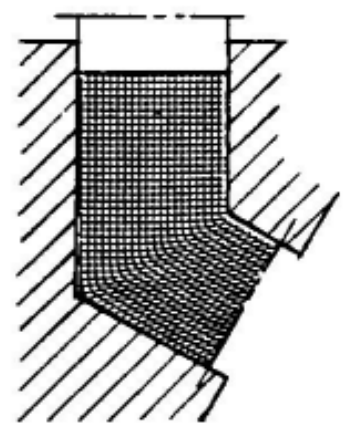

(c)

Figura 01

Processamento por Canais Equiangulares:

(a) Esquema do Processamento Mecânico por Canalização Angular Equivalente (PCE) ou Equal Channel Angular Processing (ECAP); (b) Elemento de transformação em cisalhamento simples; (c) Representação esquemática da distorção experimental da peça como uma grade sincronizada.

Fonte: Adaptado de Segal, V. M. Materials Science and Engineering A17, 1995, 157-164.

Após o processo de extrusão, o punção é retirado e o tarugo deformado é removido do segundo canal. $O$ processo pode ser repetidamente realizado na mesma ferramenta com diversas alternativas e, desta forma, a intensidade de deformação total será $\mathrm{N}$ (número de passes) vezes uma única deformação de cisalhamento. O grau de deformação em cisalhamento puro, $\gamma$, é calculado pela expressão desenvolvida por Iwahashi:

$$
\gamma=\{2 \cot (\Phi / 2+\Psi / 2)+\Psi[(\operatorname{cossec} \Phi / 2)+\Psi / 2]\}
$$

A multiplicação do processo PCE permite desenvolver diferentes microestruturas ao girar a amostra entre passes consecutivos.

$\mathrm{Na}$ Figura 02 estão ilustradas as quatro rotas básicas de processamento, onde as rotações da amostra entre passes consecutivos são: $0^{\circ}$, 
para a rota A (a amostra é extrudada sempre na mesma orientação, isto é, não se aplica rotação entre passes em torno de seu eixo longitudinal); $90^{\circ}$, para a rota $B$; $180^{\circ}$, para a rota $C$ (a amostra é girada $180^{\circ} \mathrm{em}$ relação ao eixo longitudinal após cada um dos passes). $A$ rota $B$ é ainda dividida em rotas $B_{A}$ e $B_{C}$, com rotações de $90^{\circ}$ em sentidos opostos alternados ou no mesmo sentido, após cada passe, respectivamente. Essas diferentes modalidades de extrusão influenciam o tamanho de grão e a homogeneidade de deformação(NAGASEKHAR et al, 2007; POPOV, 2012). De acordo com Langdon e colaboradores (LANGDON, 2000), a rota de processamento $B_{C}$ é preferível em relação às demais para alcançar uma microestrutura homogênea em metais CFC e HC.

O refino microestrutural e a melhoria das propriedades mecânicas são duas importantes consequências, constituindo-se a PCE um processo potencialmente capaz de aumentar ao mesmo tempo a resistência mecânica e a ductilidade, via redução do tamanho de grão. Os fatores que determinam o sucesso do processo PCE são a magnitude de deformação, a distribuição da deformação e a temperatura. Os dois primeiros são afetados pelo número de passes, ângulo do cotovelo, número e natureza da rotação entre passes, intensidade das forças de atrito, etc. $O$ valor da deformação e o grau de heterogeneidade podem ser avaliados via modelagem do processo PCE por meio da técnica de elementos finitos.

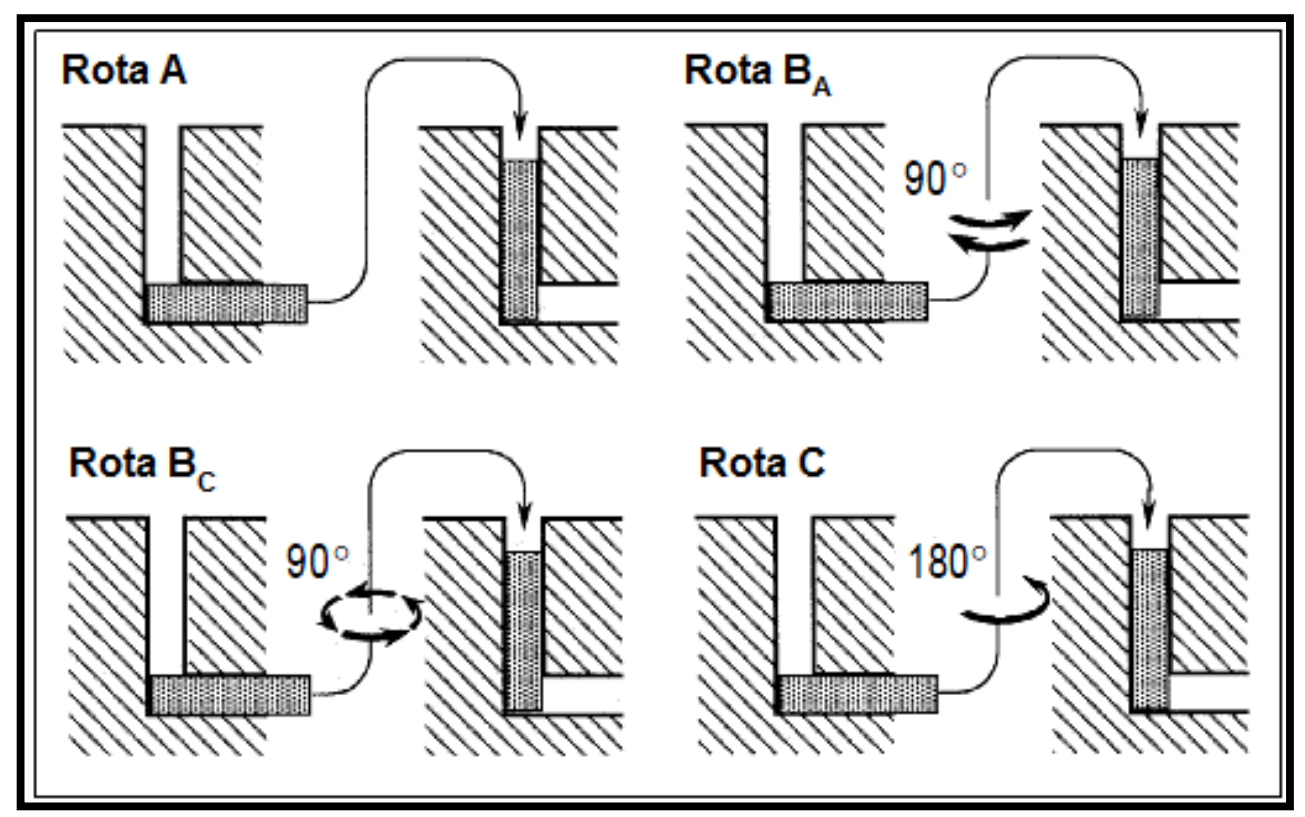

Figura 02 - Rotas de processamento por PCE (SILVA 2013). 
Estudos realizados com diferentes materiais utilizando amostras de tamanhos diferentes indicaram resultados idênticos em relação ao tamanho de grão e à tensão de escoamento, apontando que os fenômenos de deformação que acontecem durante o processo PCE são independentes do tamanho da amostra o que indica grande possibilidade da utilização desta técnica em escala industrial (YAMAGUSHI, 2000).

Os estudos atuais concentram-se na determinação da evolução microestrutural resultante da extrusão (YU, 2004; BOWEN, 2000; MEDEIROS, 2008), na influência da rotação das amostras entre um e outro passe e nas consequências da deformação aplicada sobre as propriedades mecânicas e a resistência à propagação de trincas. Outras investigações tratam do efeito de recozimentos de recristalização ou deformação em alta temperatura sobre as propriedades mecânicas, a microestrutura e textura, além de tamanho e estabilidade da estrutura de grãos e cinética de precipitação de segundas fases (MARKUSHEV, 2004; WANG, 2004; CAI, 2004).

O objetivo relativo ao aspecto tecnológico envolve o ferramental de processamento empregado para a produção de materiais metálicos UFE. Este equipamento para a rota de material massivo consiste em um molde especial adaptado e baseado em equipamento semelhante ao empregado em trabalhos internacionais e que permite a produção de cisalhamento puro no material em estudo determinando, inclusive, as condições ideais de lubrificação do referido ferramental (BOWEN 2000; LANGDON 2000; ZHERNAKOV 2001; KOCH 2003; SEGAL 2004; KIM 2005; GAO 2009).

A etapa seguinte é a avaliação do potencial de aplicação dos processos desenvolvidos em materiais massivos e sua possibilidade de aplicação em grandes escalas dependente de aspecto custo - benefício envolvido. Persistem vários parâmetros a serem explorados e discutidos, em razão dos materiais metálicos empregados serem em grande parte multifásicos, o que abre perspectivas de estudo dos mecanismos envolvidos nos processamentos mecânicos de materiais metálicos de granulometria ultrafina.

Além do grande aumento em resistência mecânica e tenacidade, mudanças importantes em propriedades físicas têm sido observadas em materiais 
ultrafinamente estruturados (UFE) quando comparados com os equivalentes materiais de grãos grosseiros.

A procura por materiais que apresentem melhor desempenho é atualmente um importante campo de pesquisa e desenvolvimento em novos materiais metálicos. Certamente a demanda para melhor uso de reservas naturais, visando menor consumo de energia e produção mais eficiente de materiais pode somente ser alcançada quando menos material é usado em aplicações especiais.

Um dos objetivos desta pesquisa é melhorar o desempenho mecânico de materiais metálicos por meio da redução do tamanho de grão a níveis nanométricos. $O$ teor da importância desta propriedade no desempenho mecânico faz da resistência mecânica dos materiais metálicos, a razão de diversos estudos científicos. (POPOV, 2012; SABIROV, 2013; POGGLIALI, 2015)

A melhoria da resistência mecânica em metais pode ser obtida de diversas formas, por exemplo, endurecimento por solução sólida, endurecimento por trabalho a frio, endurecimento por precipitação ou refinamento de grão. (SEGAL, 1981; WEERTMAN 1993; SEGAL 1995; VALIEV 2006).

O refino de grão é tecnologicamente atraente em razão de não afetar de forma adversa a ductilidade e tenacidade, contrariamente aos outros métodos de endurecimento (encruamento). A literatura tem indicado que a resistência mecânica em materiais policristalinos segue a lei de Hall-Petch (HP) e é dada pela expressão empírica:

$$
\sigma_{\mathrm{y}}=\sigma_{0}+\mathbf{k} /(\mathrm{d})^{1 / 2},
$$

onde $\mathbf{k}$ e $\sigma_{0}$ são constantes do material, $\mathbf{d}$ é o tamanho médio de grão e $\sigma_{\mathrm{y}}$ a tensão de escoamento. Esta lei não é rigorosamente seguida para tamanhos de grãos extremamente finos. Outros mecanismos são dominantes e estão associados com a estabilidade dos chamados anéis de discordâncias (imperfeições cristalinas) presentes na microestrutura.

Assim é importante determinar a relação do tamanho de grão com a tensão de escoamento para os diferentes materiais nanocristalinos e determinar a estabilidade da relação dependente do processamento inicial utilizado. Novos modelamentos são necessários para suplantar e explicar adequadamente o que ocorre em estruturas ultrafinas. 
Os metais obedecem à equação de Hall-Petch para várias ordens de grandeza em tamanho de grão, o que significa que a resistência mecânica dos materiais metálicos aumenta quando seu tamanho de grão é reduzido. (MICELIS, 2016) A literatura atual mostra que a equação não é tão válida para tamanhos de grão abaixo de certo tamanho de grão crítico, onde a resistência mecânica pode até mesmo decrescer com o tamanho de grão decrescente. Estudos recentes confirmam que ela ainda é válida para aços com tamanho de grão ferrítico de até $0,2 \mu \mathrm{m}$. (LIU et al, 2003; OHMORI et al, 2004)

Assim, esta pesquisa objetivou uma combinação ideal de ductilidade e resistência mecânica, procurando atingir tamanhos nanométricos de grão (aproximadamente $100 \mathrm{~nm}$ ).

O material utilizado neste estudo envolveu comparação entre duas ligas a base de alumínio (AA 3003 e AA 1050) visando possível melhoria em suas resistências mecânicas através do processo PCE. As diferenças de raio atômico existentes $(r)$ entre os três elementos químicos principais $\left(r_{A l}=118 \mathrm{pm} ; r_{\mathrm{Mg}}=145\right.$ $\mathrm{pm} ; \mathrm{r}_{\mathrm{Mn}}=161 \mathrm{pm}$ ) podem ter influenciado na difusão destes elementos durante os mecanismos envolvidos no processamento por PCE e possíveis tratamentos térmicos posteriores. A Tabela 01 apresenta a composição química dos principais elementos de liga presentes nas ligas de alumínio AA 3003 e AA 1050, para comparação, conforme ABNT NBR ISO 209:2010.

O alumínio e suas ligas constituem um dos materiais metálicos mais versáteis, econômicos e atrativos para uma vasta série de aplicações. Sua aplicação como metal estrutural só é menor que a dos aços. O alumínio possui uma densidade de $2,7 \mathrm{~g} / \mathrm{cm}^{3}$, aproximadamente $1 / 3$ da do aço, o que somado à sua elevada resistência mecânica o torna bastante útil na construção de estruturas móveis como veículos, aeronaves e produtos da indústria naval. $\mathrm{O}$ alumínio não é ferromagnético, possui elevadas condutividades térmica e elétrica, e não é tóxico. Tem resistência à oxidação progressiva, já que os átomos da sua superfície se combinam com o oxigênio da atmosfera, formando uma camada de óxido protetor que impede a progressão da degradação do material. 
Tabela 01 - Composição química das ligas de alumínio AA 1050 e AA 3003.

\begin{tabular}{|c|c|c|}
\hline & AA 1050 & AA 3003 \\
\hline (\%) ELEMENTO & 99,50 (mín) & 97,55 (mín) \\
\hline $\mathrm{Si}$ & 0,05 & 0,60 \\
\hline $\mathrm{Fe}$ & 0,25 & 0,70 \\
\hline $\mathrm{Cu}$ & 0,40 & $0,05-0,20$ \\
\hline $\mathrm{Mn}$ & 0,05 & $1,00-1,50$ \\
\hline $\mathrm{Mg}$ & 0,05 & - \\
\hline $\mathrm{Cr}$ & - & - \\
\hline $\mathrm{Zn}$ & 0,05 & 0,10 \\
\hline $\mathrm{Ti}$ & 0,03 & - \\
\hline
\end{tabular}

A seguir são apresentados, conforme normas ABNT NBR 7549:2012, os dados disponíveis na literatura das ligas de alumínio envolvidas no desenvolvimento desta pesquisa.

\subsection{Liga Al 1050}

O material metálico da série $1 \mathrm{XXX}$ é classificado pela Aluminum Association (AA) como o alumínio puro, desde o percentual de pureza de 99,00\% (indicado por 1000), até $99,99 \%$ (indicado 1099). Desta forma, tomando-se os dois últimos algarismos do indicador da série como o seu grau de pureza, tem-se que a liga AA 1050 é uma liga de alumínio puro com 99,50\% de pureza. (HATCH, 1990; METALS HANDBOOK, 1998 )

O alumínio comercialmente puro caracteriza-se pelas elevadas condutividades térmica e elétrica e pela baixa resistência mecânica. Suas principais aplicações estão ligadas aos componentes de sistemas térmicos e elétricos, onde se exige alta condutividade sem a necessidade de elevadas propriedades mecânicas. O alumínio comercialmente puro tem elevada 
resistência à corrosão, devido à formação de uma camada de óxido de alumínio $\left(\mathrm{Al}_{2} \mathrm{O}_{3}\right)$, muito fina, transparente e extremamente aderente que confere essa característica ao impedir o prosseguimento da oxidação (remoção dos óxidos). Essa alta resistência à corrosão pode ser diminuída pela introdução de elementos de liga, como o cobre, por exemplo. Outros elementos próximos ao alumínio, na tabela periódica, como o magnésio, não afetam sobremaneira a resistência à corrosão do alumínio. Por este motivo, as ligas Al-Mg são aquelas que apresentam a maior resistência à corrosão, inferior somente à do alumínio comercialmente puro (GOMES, 1987; METALS HANDBOOK, 1998; HATCH, 1990).

Os elementos mais comumente encontrados como impurezas no alumínio comercialmente puro são o ferro e o silício, em maior ou menor grau, dependendo do nível de pureza. Em razão da limitada solubilidade do ferro e silício no alumínio eles formam fases intermetálicas, como $\mathrm{FeAl}_{3}, \mathrm{Fe}_{3} \mathrm{SiAl}_{12}$, $\mathrm{FeSiAl}_{8}, \mathrm{FeSiAl}_{5}$, e $\mathrm{Fe}_{2} \mathrm{Si}_{2} \mathrm{Al}_{9}$. Estas fases apresentam-se com diferentes tamanhos, formas e distribuição, mas normalmente só prejudicam as propriedades da matriz quando são grosseiras, alongadas e concentradas nos contornos de grão (HATCH, 1990; METALS HANDBOOK, 1998).

\subsection{Ligas Al-Mn}

As ligas Al-Mn (série $3 X X X$ da Aluminum Association, entre as ligas trabalhadas) não são endurecíveis por precipitação, ou seja, não se obtêm nenhum ganho de dureza mediante tratamento térmico (o chamado envelhecimento). Como as ligas dos sistemas Al-Si (série 4XXX) e Al-Mg (série 5XXX) (Al-Mg), as ligas Al-Mn somente podem ser endurecidas por encruamento (trabalho mecânico). Entretanto, as ligas não tratáveis termicamente contendo mais de $1 \%$ de manganês, como a 3003 , muito utilizada na fabricação de latas e panelas, possuem considerável importância comercial. Outro exemplo de liga do sistema Al-Mn com ampla aplicação industrial é a 3004, utilizada na fabricação de recipientes acondicionadores de líquidos (outros elementos de liga também podem estar presentes: $\mathrm{Si}, \mathrm{Fe}, \mathrm{Cu}, \mathrm{Mg}, \mathrm{Zn}$ e $\mathrm{Cr}$ ). Efeito importante do manganês no alumínio e suas ligas é a redução da susceptibilidade à corrosão sob tensão. (GOMES, 1987; HATCH, 1990). 
O manganês de um modo geral aumenta a resistência mecânica das ligas trabalhadas, seja através da formação de fases intermetálicas ou por meio de endurecimento por solução sólida. Entretanto, em quantidade excessiva as fases intermetálicas podem reduzir a ductilidade. A temperatura eutética nas ligas Al-1,9\% de Mn ocorre a $660^{\circ} \mathrm{C}$. O limite de solubilidade do manganês no alumínio nesta temperatura é $1,8 \%$. A fase intermetálica que existe em equilíbrio com a solução sólida de alumínio tem uma composição que corresponde praticamente à fase $\mathrm{Al}_{6} \mathrm{Mn}$. Esta fase separa-se da fase líquida que contém 1,9 a $4,1 \%$ de manganês. Quando as soluções sólidas possuem maiores teores, ela se forma pela reação proeutética entre $\mathrm{Al}_{4} \mathrm{Mn}$ e a fase líquida a $710^{\circ} \mathrm{C}$ (GOMES, 1987; $\mathrm{HATCH}, 1990)$. A única fase metaestável conhecida no sistema Al-Mn tem a composição $\mathrm{Al}_{12} \mathrm{Mn}$ com $14,5 \%$ de manganês. Caso as ligas tenham $\mathrm{Fe}$ e $\mathrm{Si}$ acima de $0,2 \%$ haverá supressão da formação de $\mathrm{Al}_{12} \mathrm{Mn}$. Por outro lado, a presença de Cr estabiliza essa fase.

A liga 3003, bastante utilizada, consiste basicamente na adição de manganês ao alumínio comercialmente puro. As fases preponderantes são $\mathrm{Al}_{6}(\mathrm{MnFe})$ e $\mathrm{Al}_{12}(\mathrm{FeMn})_{3} \mathrm{Si}$. Durante a solidificação predomina a fase que não contém silício, porém o aquecimento posterior leva à formação da fase que contém silício. O manganês também precipita sob a forma de partículas dispersóides, os quais dificultam muito a recristalização durante o recozimento posterior à deformação, quando comparada com o alumínio comercialmente puro, que praticamente não contem esses dispersóides (BURGER, 1995; LUCAS, 1996; METALS HANDBOOK, 1998).

O manganês possui baixíssima solubilidade na matriz de alumínio (estrutura cristalina $\mathrm{CFC}$ ), cerca de $1 \%$ em peso a $600^{\circ} \mathrm{C}$, devido a grande diferença de raio $(11,3 \%)$ e diferente estrutura cristalina (CCC) tendendo a formar segunda fase. A presença de ferro e silício favorecem a formação da fase quaternária $\mathrm{Al}_{12}(\mathrm{MnFe})_{3} \mathrm{Si}$ e na presença de cobre ocorre a formação da fase ternária $\mathrm{Al}_{20} \mathrm{Cu}_{2} \mathrm{Mn}_{3}(\mathrm{HATCH}, 1990$, COLE 1995).

Entretanto, nas ligas $3 \mathrm{XXX}$ parte do manganês permanece em solução sólida. Algumas ligas desse sistema também contêm magnésio, que 
devido à sua grande afinidade com o silício tende a favorecer a formação da fase $\mathrm{Al}_{6}(\mathrm{MnFe})$. A liga 3003 da classe Al-Mn é a mais antiga no mercado, tendo sido introduzida em 1906, mas ainda é a de maior importância econômica. Outras ligas da série $3 X X X$, como a 3005 e a 3105 , somente vieram a ser desenvolvidas nas décadas 50 e 60, respectivamente, o que ampliou as possibilidades de utilização das ligas da série. A resistência mecânica da liga 3003 é significativamente mais elevada do que a do alumínio comercialmente puro. Pode-se afirmar que as ligas Al-Mn possuem melhores propriedades mecânicas que 0 alumínio comercialmente puro, ductilidade ligeiramente inferior e boa resistência à corrosão (HATCH, 1990).

O elemento principal de liga na série $3 X X X$ é o manganês e, embora as ligas desta série $(3003,3004,3105)$ não sejam tratadas termicamente, elas apresentam resistência mecânica superior em relação às ligas da série $1 X X X$, em $20 \%$. A existência de apenas três ligas da série $3 X X X$ com largo consumo na indústria se dá devido ao fato da baixa solubilidade do manganês no alumínio, algo que vai até $1,8 \%$. As aplicações principais das ligas da série 3XXX estão em: (a) componentes de resistência mecânica baixa que exijam elevada ductilidade; (b) latas de bebidas; (c) utensílios de cozinha; (d) trocadores de calor; (e) tanques de armazenamento; (f) sinalização rodoviária; (g) painéis decorativos e telhados para uso na construção civil.

A Figura 03 apresenta o diagrama de fases desta liga binária, alumínio-manganês. A adição de $1,2 \% \mathrm{Mn}$ no alumínio comercial puro (0,6\% Fe e $0,2 \% \mathrm{Si}$ ) produz uma moderada resistência à liga de alumínio não tratada termicamente. A adição de manganês aumenta a resistência da liga por solução sólida e pela fina dispersão de precipitados. Esta resistência pode ser aumentada pela adição de aproximadamente $1 \%$ de magnésio. Estas ligas são geralmente utilizadas quando moderada resistência e boa trabalhabilidade são necessárias. 


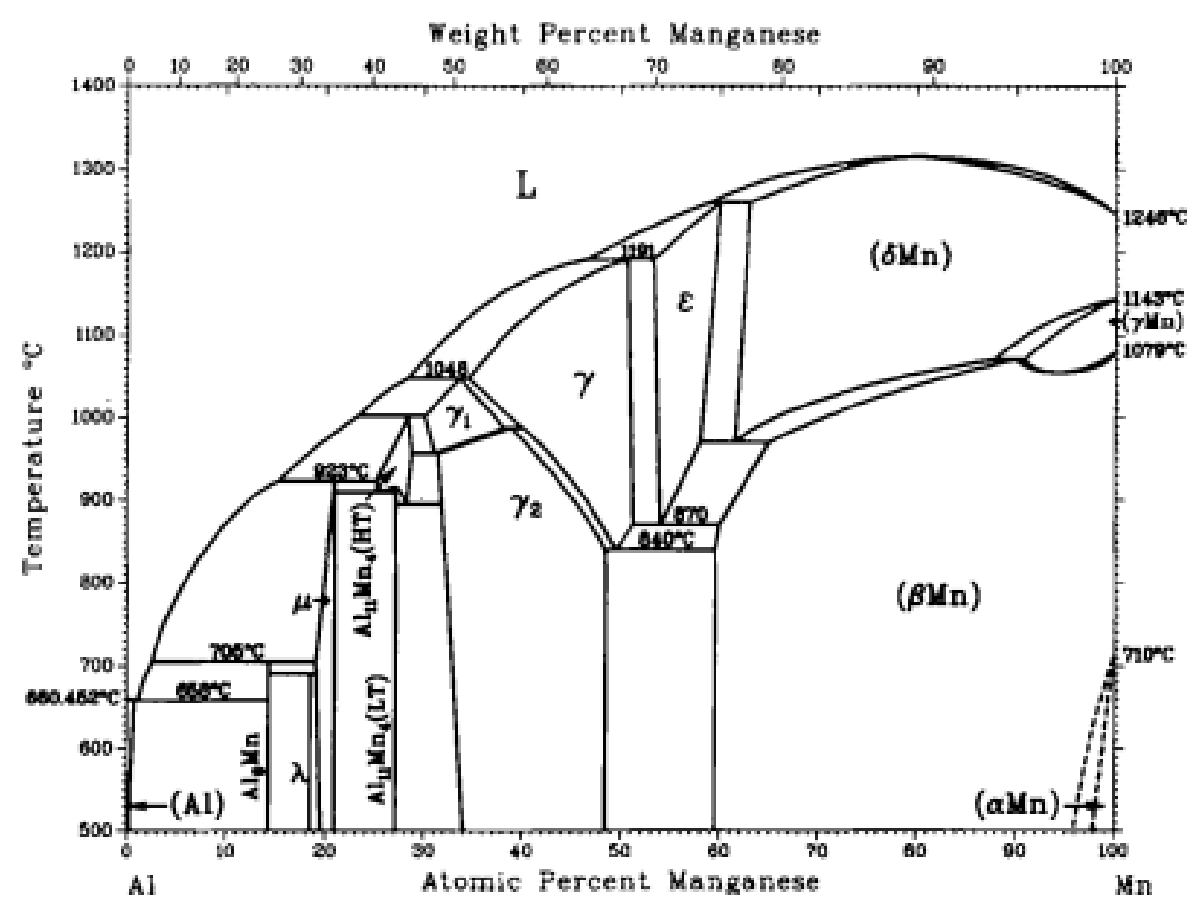

Figura 03. Diagrama de fases da liga Al-Mn (McAlister and Murray, 1987).

Vale pontuar que a utilização das ligas da série $5 X X X$ é bem similar à da série $3 X X X$, o que torna o entendimento dos mecanismos de melhora nas propriedades mecânicas destas ligas de grande interesse para a indústria do alumínio. (HATCH, 1990; VAN HORN, 1967; METALS HANDBOOK, 1998; EEIMVR-UFF, 2009).

As ligas Al-Mg (série 5XXX) constituem um importante grupo de ligas de alumínio não tratáveis termicamente, ou seja, não são endurecíveis por tratamento térmico de solubilização e envelhecimento, mas sim por solução sólida e encruamento (trabalho mecânico). Além desse ganho de resistência mecânica, o magnésio permite a essas ligas manterem um elevado nível de ductilidade, assim como excelente resistência à corrosão e soldabilidade. As ligas Al-Mg com teores variando entre 3 e $5 \%$ são muito utilizadas na indústria naval, na fabricação de diversos componentes de navios, na fabricação de tampas para latas de bebidas, na indústria automobilística e também como metais de adição na soldagem. O magnésio é o elemento de liga principal na série $5 X X X$ e é um dos elementos mais efetivos no endurecimento do Al. Quando utilizado como 
elemento principal ou em conjunto com o $\mathrm{Mn}$, o resultado são ligas não tratáveis com resistência moderada à elevada.

Para propósitos gerais e estruturais, as ligas de Al-Mg contém de 1 a pouco mais de $5 \%$ de $M g$ e é muito difundida na indústria. São poucas as ligas binárias de alumínio-magnésio trabalháveis (endurecidas por encruamento), como é o caso da serie 5005. Para aumentar esta resistência, a maioria das ligas de alumínio- magnésio contém um pouco de manganês $(0,1$ a $1,0 \%)$ e/ou cromo $(0,1$ a $0,2 \%)$.

Reafirmando, o objetivo desta pesquisa é processar, por deformação plástica intensa, as ligas de alumínio AA 3003 e AA 1050 para obtenção de estrutura de grãos ultrafinos (submicrométrico e talvez nanométrico) que possuam propriedades mecânicas especiais, como resistência mecânica de ligas binárias de alumínio endurecidas por encruamento (cold worked) com aceitável tenacidade e estampabilidade e desta forma perfeitamente adequadas em utilização estrutural. A liga AA 1050 foi tomada como base de comparação por ser composta praticamente de alumínio puro, conforme caracterizações mostradas na pesquisa. E, quando colocada frente aos parâmetros da liga AA 3003 (Al-Mn), foi possível propor uma nova opção para uso de um material com melhor performance. 


\section{MATERIAIS E MÉTODOS}

\subsection{Preparação das amostras}

Os corpos de prova utilizados nos experimentos deste trabalho foram produzidos a partir de duas placas, uma da liga AA 1050, outra da liga AA 3003, obtidas pelo processo de laminação a quente e cedidas pela Companhia Brasileira do Alumínio (CBA). Elas foram cortadas a jato de água e usinadas em tarugos com formato de paralelepípedo, cuja secção transversal quadrada possui dimensões aproximadas de $6,0 \mathrm{~mm} \times 6,0 \mathrm{~mm}$. Os corpos de prova possuem comprimento de $20 \mathrm{~mm}$ ou $30 \mathrm{~mm}$ para a liga AA 1050 e de $50 \mathrm{~mm}$ para a liga AA 3003, conforme os exemplares mostrados na Figura 04.
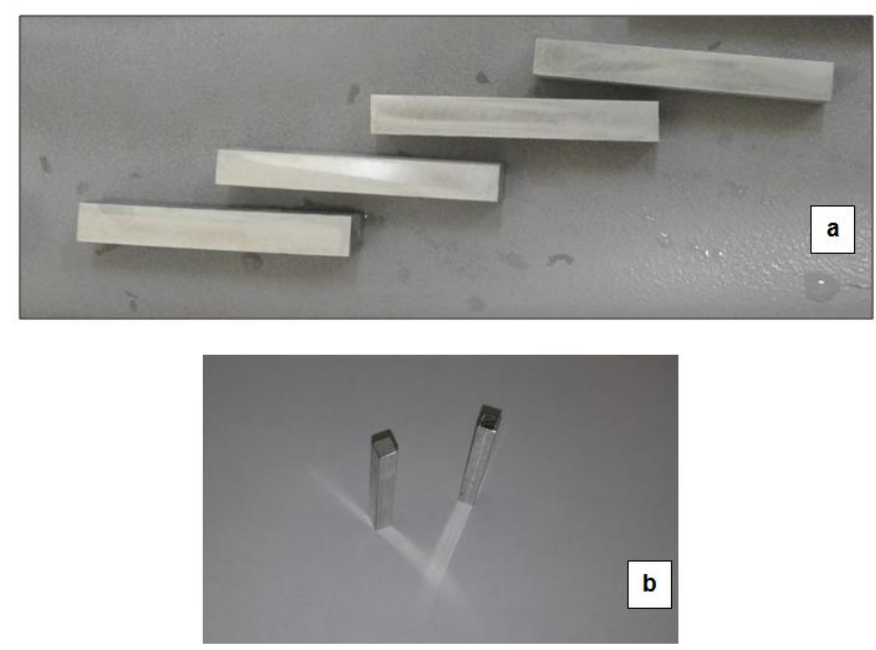

Figura 04. Exemplares dos corpos de prova obtidos pelo método de laminação a quente. a) Liga AA 3003; b) Liga AA 1050.

Após o corte das placas foram produzidos quarenta tarugos (aqui também chamados de corpos de prova ou amostras) da liga AA 1050. Vinte com comprimento de $20 \mathrm{~mm}$ e os outros com comprimento de $30 \mathrm{~mm}$, adequados à técnica de prensagem por canais equiangulares (PCE) (GUERRA, 2015). Da liga AA 3003 foram produzidas noventa amostras com comprimento de $50 \mathrm{~mm}$. Parte das amostras das duas ligas foi embutida, lixada, polida e submetida a ataque químico para ser analisada após a microscopia óptica (MO) e eletrônica (MEV), e categorizada por "material como recebido". O microscópio eletrônico de varredura (MEV), através do seu acessório de EDS - Energy Dispersive Spectroscopy ou 
espectroscopia por energia dispersiva forneceu o espectro de dispersão de energia dos elementos químicos que compõem as ligas de alumínio em estudo, conforme os resultados vistos no próximo capítulo desta pesquisa. Amostras da liga AA 3003 foram também submetidas à caracterização elétrica para a aferição da sua condutividade elétrica. A caracterização mecânica foi verificada no ensaio de dureza Vickers, naquele momento dos procedimentos experimentais.

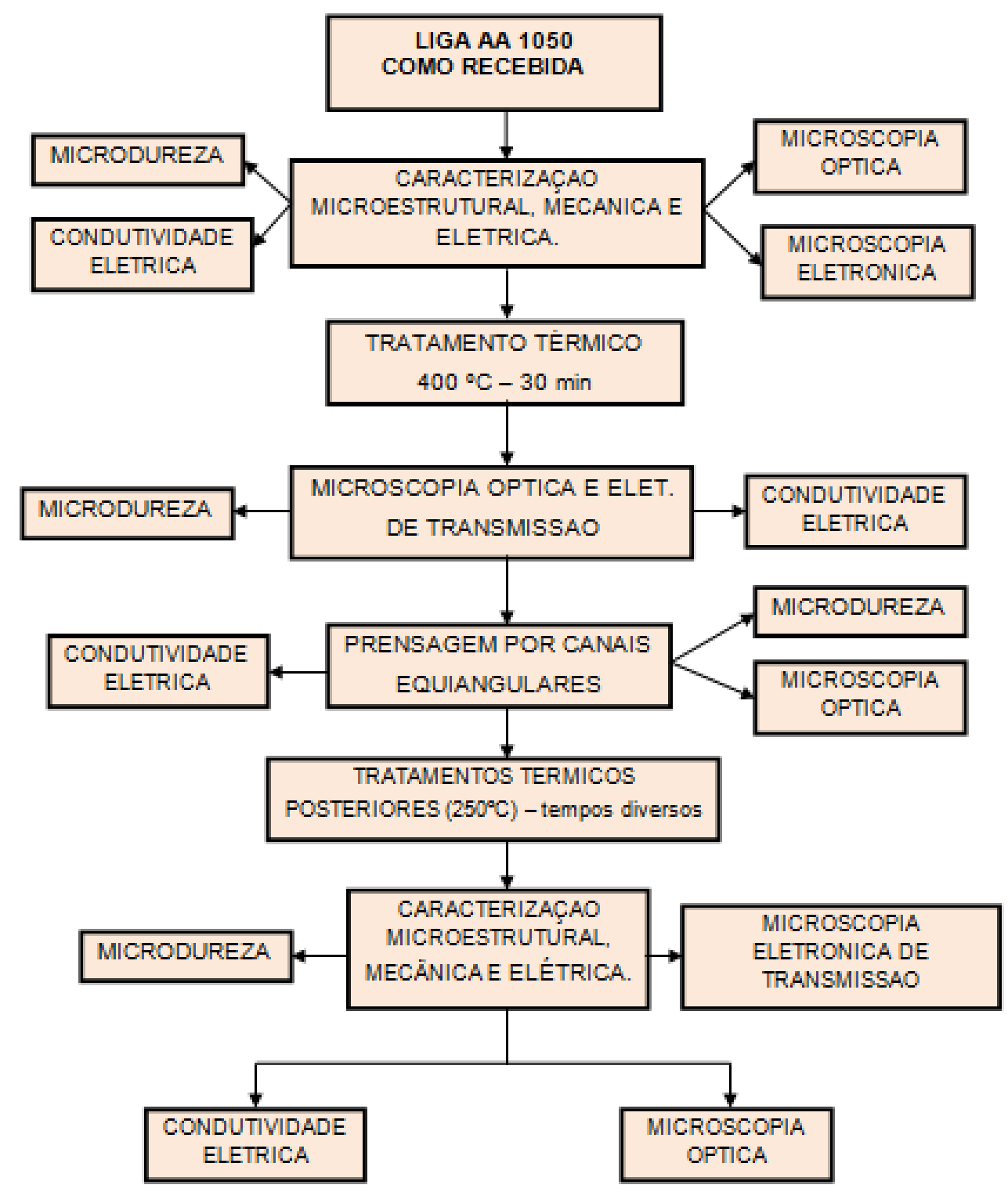

Figura 05. Fluxograma das etapas de procedimentos - Liga de Alumínio AA 1050. 
Dois fluxogramas com as etapas dos procedimentos experimentais, Figuras 05 e 06, foram construídos para que, ao final do cumprimento das etapas estipuladas, as caracterizações das amostras do material de cada liga, (AA 3003 e AA 1050), fossem confrontadas com as caracterizações do material como recebido no início da pesquisa e também comparadas as diferenciações comportamentais entre as ligas estudadas.

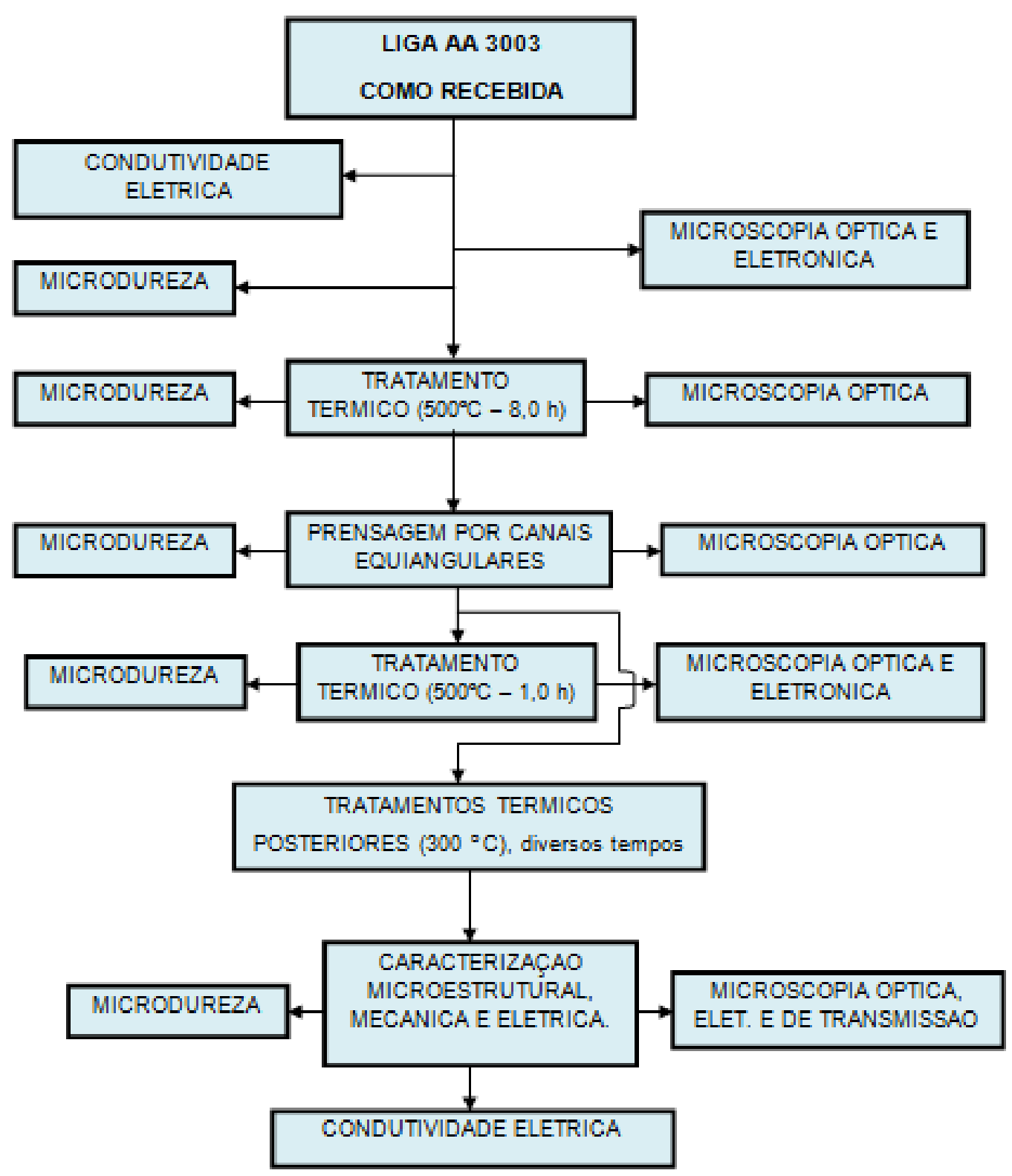

Figura 06. Fluxograma das etapas de procedimentos - Liga de Alumínio AA 3003. 


\subsection{Tratamentos Térmicos}

Os tratamentos térmicos foram aplicados com o intuito de diminuir o acúmulo de tensões residuais nos materiais das ligas, advindo do processo de produção do alumínio. As amostras da liga AA 1050 foram recozidas por $30 \mathrm{~min}$ em banho de $400{ }^{\circ} \mathrm{C}$, na mufla do laboratório de Tratamentos Térmicos do CCTM/IPEN, e resfriadas em ar, na temperatura ambiente. Depois que os tarugos desta liga passaram pelos mecanismos da PCE, uma parte deles seguiu para caracterização microestrutural, mecânica e elétrica descrita no tópico seguinte da pesquisa, enquanto a outra parte foi submetida a um tratamento térmico final de envelhecimento à temperatura de $250{ }^{\circ} \mathrm{C}$, pelos tempos de $30,60,90$ e 120 minutos, objetivando a restauração e recristalização da microestrutura do material, que the conferiram refinamento de grãos, tenacidade e resistência mecânica simultâneos.

Os tarugos da liga AA 3003 foram colocados na mufla do laboratório da Companhia Brasileira do Alumínio (CBA), no momento em que a temperatura desta estava a $50^{\circ} \mathrm{C}$. A partir de então cumpriram o programa de uma rampa com a taxa de $150 \stackrel{\circ}{\circ} / \mathrm{h}$ e após 3,0 horas, quando atingiram a temperatura de $500 \stackrel{\circ}{\circ}$ ficaram em banho por mais $8,0 \mathrm{~h}$. O resfriamento ocorreu em ar à temperatura ambiente. Depois que os tarugos desta liga passaram pelos processos da PCE, uma parte foi encaminhada para a caracterização microestrutural e mecânica e em seguida foi submetida a um recozimento por sessenta minutos, a $500 \stackrel{\circ}{\circ}$. A outra parte dos tarugos da liga AA 3003 foi levada a um envelhecimento a $300^{\circ} \mathrm{C}$ pelos intervalos de tempo de 30,60, 90 e $120 \mathrm{~min}$, com o objetivo de observar a evolução da recristalização e do refinamento dos grãos do material.

\subsection{Caracterização Microestrutural, Mecânica e Elétrica após Tratamentos Térmicos}

Após a realização dos tratamentos térmicos descritos no subtópico 4.2., os tarugos foram cortados, embutidos, lixados, polidos e atacados quimicamente para a caracterização microestrutural. As amostras da liga AA 1050 foram observadas por microscopia óptica (MO) e eletrônica de transmissão (MET) 
após o tratamento térmico inicial e foram ainda submetidas aos ensaios de dureza Vickers (HV) e condutividade elétrica. Após os processos de PCE, parte das amostras foi caracterizada por $\mathrm{MO}$, ensaiada por microdureza e teve a sua condutividade térmica medida. Seguindo o envelhecimento as amostras foram preparadas para a caracterização microestrutural, por MO e MET, mecânica por microdureza Vickers (HV) e tiveram a sua condutividade elétrica medida.

As amostras da liga AA 3003 tiveram a caracterização microestrutural e mecânica efetuada após cada etapa do fluxograma apresentado, com a adição da medida da condutividade elétrica realizada no material como recebido e após a última etapa quando o material foi submetido a um envelhecimento. Para a verificação da microtextura e planos cristalográficos associados, após o envelhecimento as amostras foram analisadas depois de submetidas ao processo EBSD (Electron BackScatter Diffraction) ou difração de elétrons retro espalhados.

\subsection{Prensagem por Canais Equiangulares (PCE)}

O refinamento dos grãos dos materiais que compõem as ligas da pesquisa foi obtido pela deformação plástica intensa DPI deste material, associada ao mecanismo de prensagem por canais equiangulares PCE dos tarugos de cada uma das ligas. A DPI sofrida pelo material provocou o seu encruamento e foi realizado de maneira a impedir o deslocamento das discrepâncias do material, posto que no processo, não ocorre a variação nas dimensões da secção transversal do tarugo prensado. É assim que estas discrepâncias se sobrepõem gerando uma estrutura de grãos altamente refinados.

A técnica PCE nesta pesquisa foi realizada em temperatura ambiente, no laboratório de caracterização de materiais da Universidade Presbiteriana Mackenzie, com a utilização da máquina de ensaio universal marca Test - ZD 100 PU, mostrada na Figura 07. 


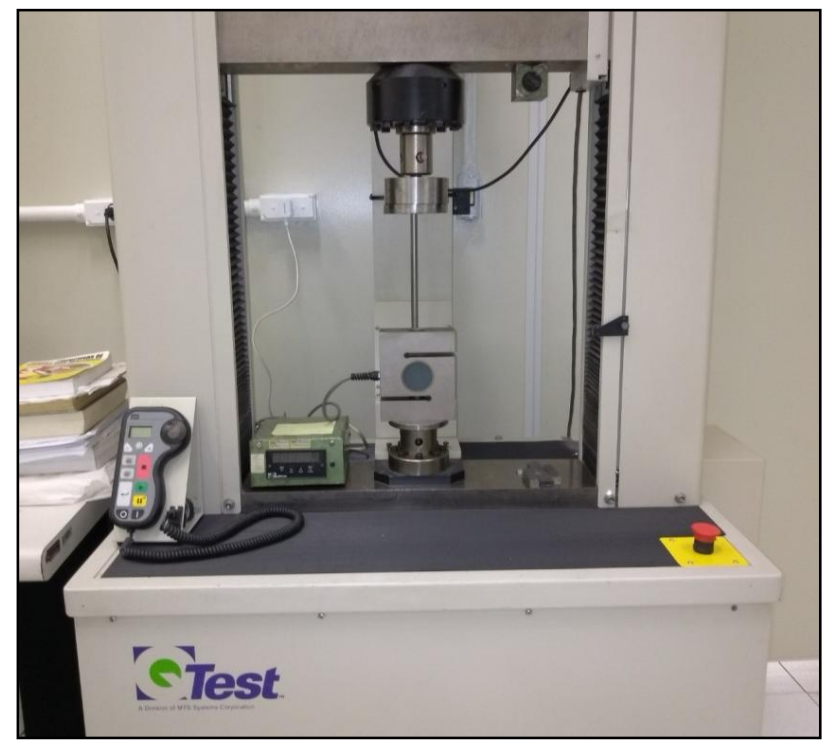

Figura 07. Máquina de Ensaio Universal Test - ZD 100 PU - (UPM).

Sob a pressão exercida por esta máquina, que trabalha no sentido da compressão, conforme Figura 08, está o punção, usinado com aço ferramenta D2, com secção transversal quadrada de dimensões 5,95 mm x 5,95 mm, mostrado na Figura 08. Este punção é acessório de uma matriz fabricada exclusivamente para o mecanismo PCE.

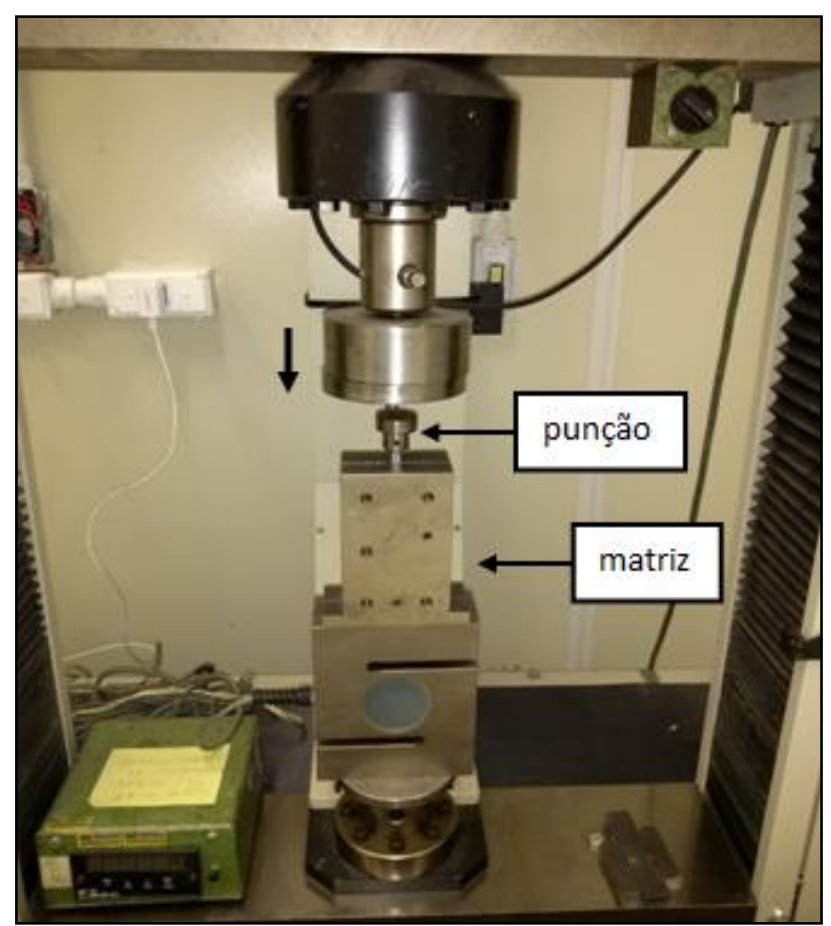

Figura 08. Máquina de Ensaio Universal com matriz e punção. 


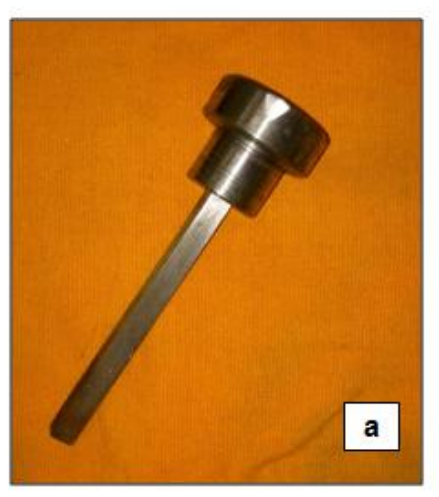

Figuras 09. Punção, acessório

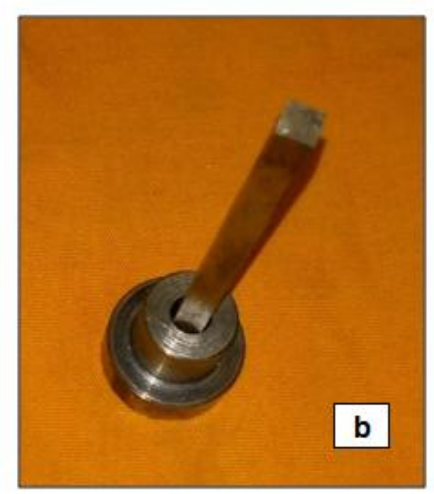

da matriz usada na PCE. a) vista de perfil; b) vista inclinada de topo.

A matriz é uma peça bipartida, produzida em aço ferramenta D2, cujo tratamento térmico lhe confere dureza $746 \mathrm{HV}$. Ela possui dois canais retangulares que formam entre si um ângulo de 120ํㅡ, conforme revela a Figura 10. A matriz é fechada e a união dos canais forma dois túneis interligados de secção transversal quadrada de dimensões $6,0 \mathrm{~mm} \times 6,0 \mathrm{~mm}$, cuja entrada forma $90^{\circ}$ com a superfície externa superior da peça e a saída $30^{\circ} \mathrm{com}$ a normal à superfície lateral, mostrados na Figura 10. Suas partes quando unidas são fixadas por cinco parafusos de aço que resistem aos esforços empreendidos e um guiamacho fixado em uma das partes que, acoplado à outra parte auxilia no apoio ao não deslocamento entre si.

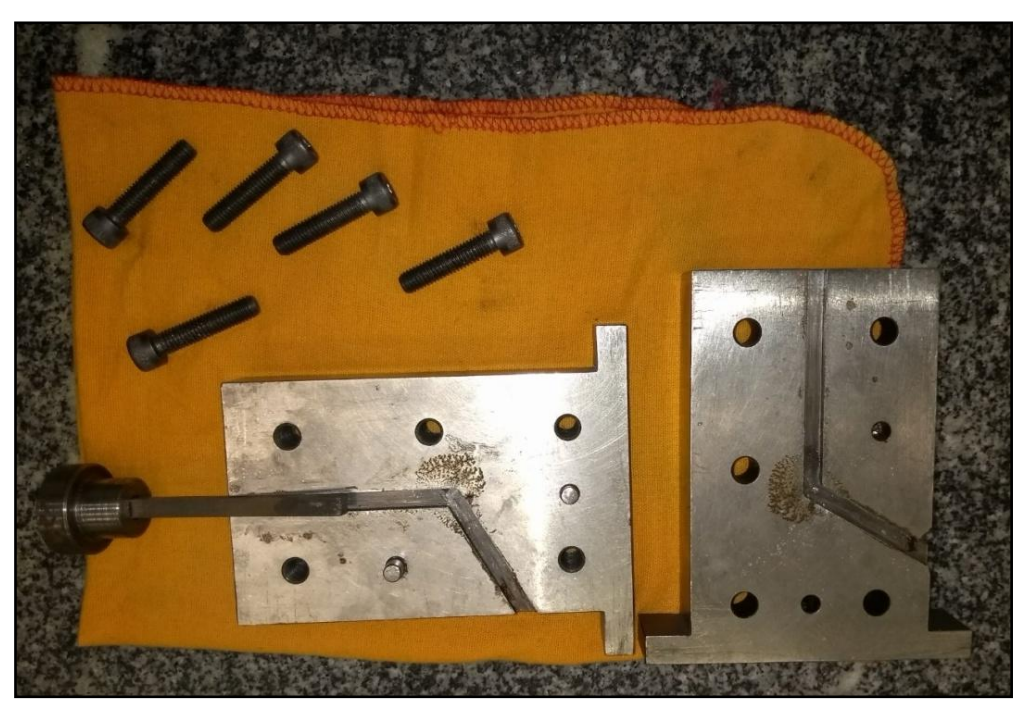

Figura 10. Matriz utilizada na técnica PCE. 
Conforme foi mostrado na Figura 02, rotas distintas podem ser realizadas no uso da matriz, dependendo das rotações que o ensaísta efetue no corpo de prova. $\mathrm{E}$ pode haver ainda um número $\mathrm{N}$ de passes, que representa a quantidade de vezes que a amostra foi passada pela matriz em uma mesma rota. Foram escolhidas para as ligas desta pesquisa duas rotas de prensagem: a rota $\mathrm{A}$ e a rota $B c$ que, segundo a literatura, para materiais com sistemas cristalinos cúbico de face centrada (CFC) e hexagonal compacta $(\mathrm{HC})$, fornece microestrutura mais homogênea que as demais rotas.(LANGDON, 2000).

Da liga AA 1050 é separado um lote com dez tarugos, cinco com 20 $\mathrm{mm}$ de comprimento e cinco com $30 \mathrm{~mm}$ de comprimento que efetuam 4 passes pela rota $A$. Os outros dez tarugos com comprimentos iguais aos do primeiro lote efetuam 4 passes pela rota $\mathrm{Bc}$, conforme resumo de distribuição das amostras para PCE da liga AA 1050, da Figura 11.

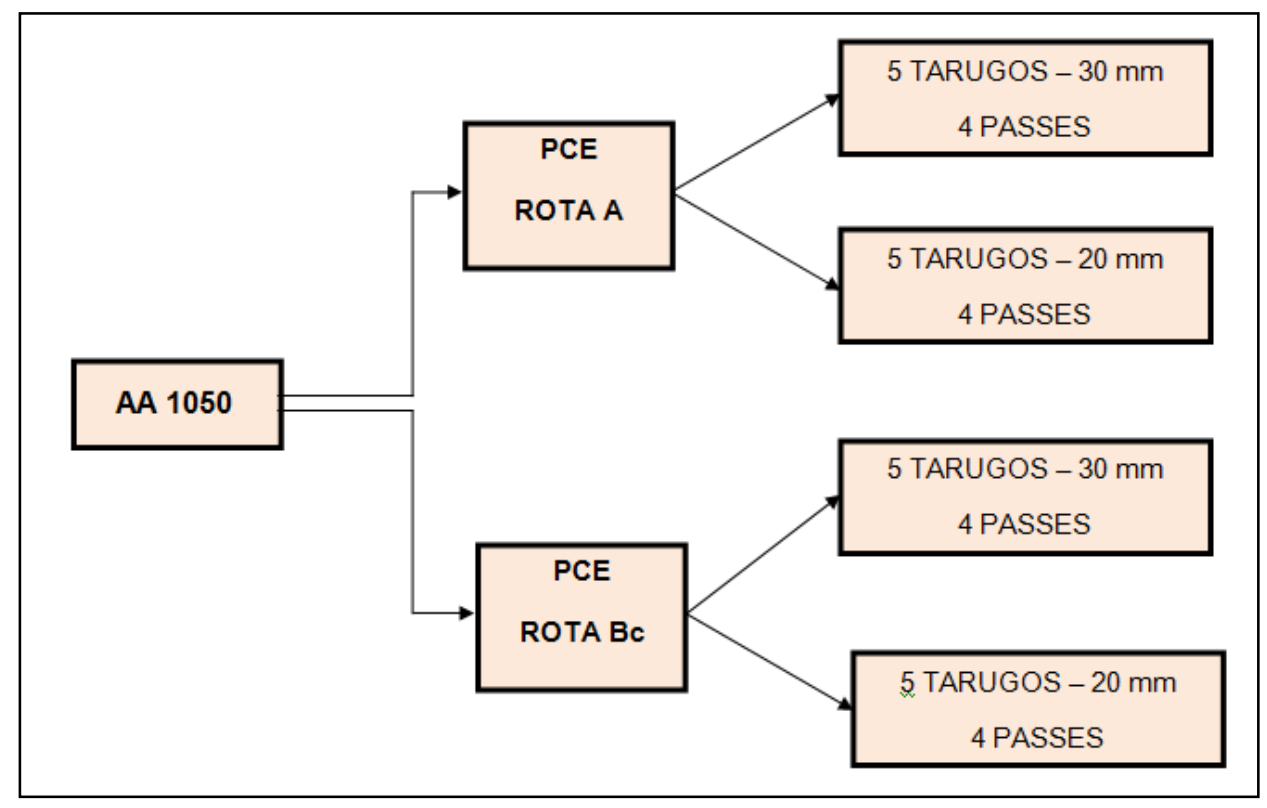

Figura 11. Resumo de distribuição das amostras para PCE - Liga AA 1050.

Em relação à liga $A A 3003$ são separados dezesseis tarugos, oito para PCE na rota $A$ e oito para PCE na rota $B c$. Tanto na rota $A$, quanto na rota $\mathrm{Bc}$, a quantidade de passagens pela matriz de cada tarugo obedece aos 
propósitos das observações e ensaios que devem ser efetuados ao longo das etapas descritas pelos fluxogramas.

Assim, para a liga AA 3003 tem-se dois tarugos com 1 passe, dois com 2 passes, dois com 3 passes e dez com 4 passes, como se observa no resumo de distribuição das amostras para PCE da liga AA 3003, da Figura 12.

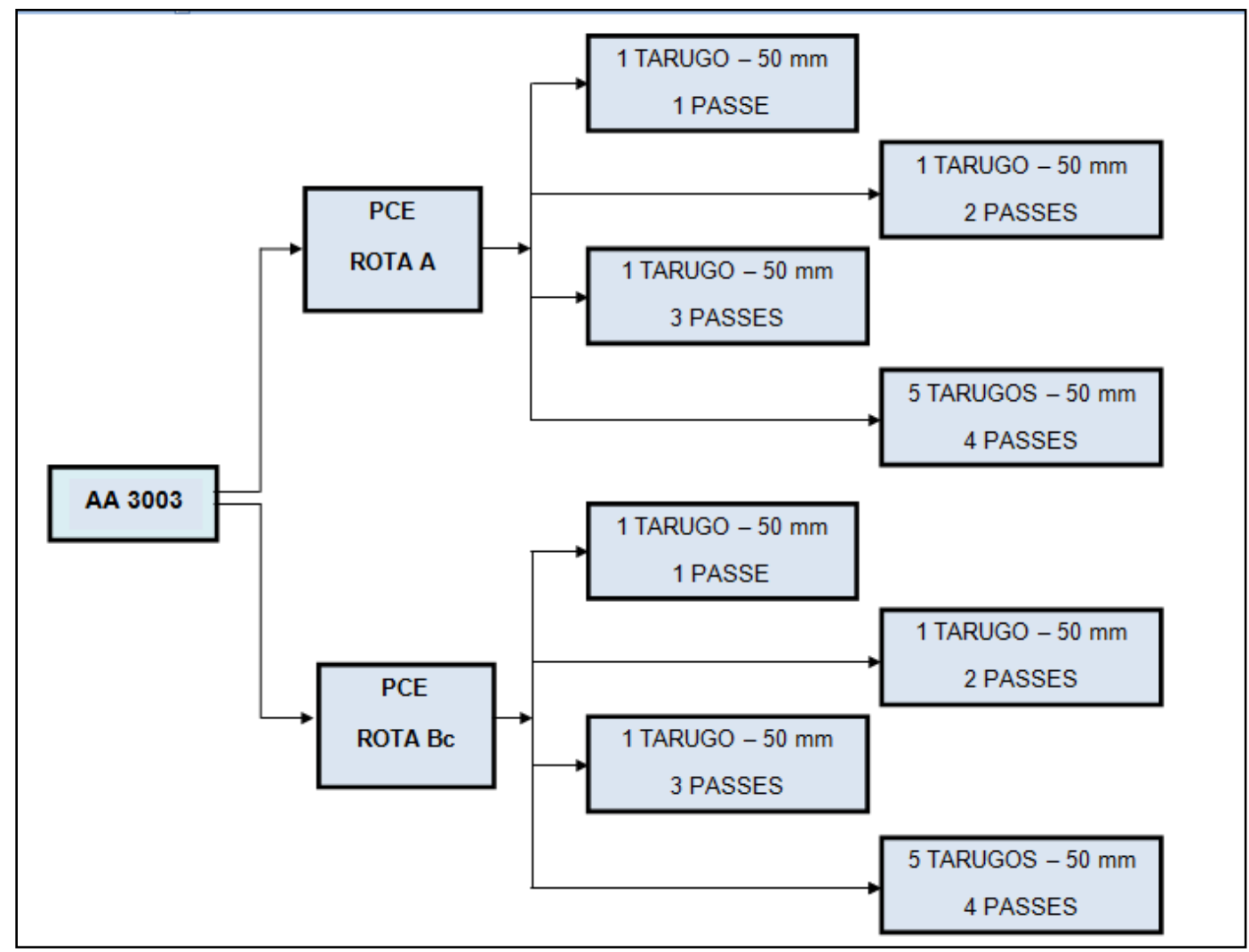

Figura 12. Resumo de distrubuição das amostras para PCE - Liga AA 3003.

\subsection{Caracterização Microestrutural, Mecânica e Elétrica após}

PCE

Seguindo o fluxograma de etapas experimentais da Figura 05, os tarugos da liga AA 1050, depois de submetidos ao mecanismo PCE, sofreram o preparo descrito no subtópico 4.1. e seguiram para a caracterização microestrutural, mecânica e elétrica. Como amostras embutidas, foram analisadas após microscopia óptica (MO), eletrônica de varredura (MEV) e eletrônica de 
transmissão (MET). A caracterização mecânica foi realizada com o ensaio de dureza Vickers (HV) do material e a elétrica com a medição de sua condutividade.

Dos tarugos da liga AA 3003, que foram ensaiados segundo o fluxograma da Figura 06, um tarugo representante de cada quantidade de passes nas duas rotas, logo, oito tarugos, seguiram para a caracterização microestrutural e mecânica. A seguir, para aliviar as tensões internas sofridas em procedimentos anteriores, sofreram recozimento a $500^{\circ} \mathrm{C}$ por uma hora e novamente foram submetidos à caracterização microestrutural e mecânica. Os outros oito tarugos restantes, que sofreram quatro passes pela rota $\mathrm{A}$ ou pela rota $\mathrm{Bc}$, foram submetidos a novos tratamentos térmicos efetuados com intervalos de tempo diversos, conforme esquema da caracterização da liga AA 3003 após PCE, visto na Figura 13.

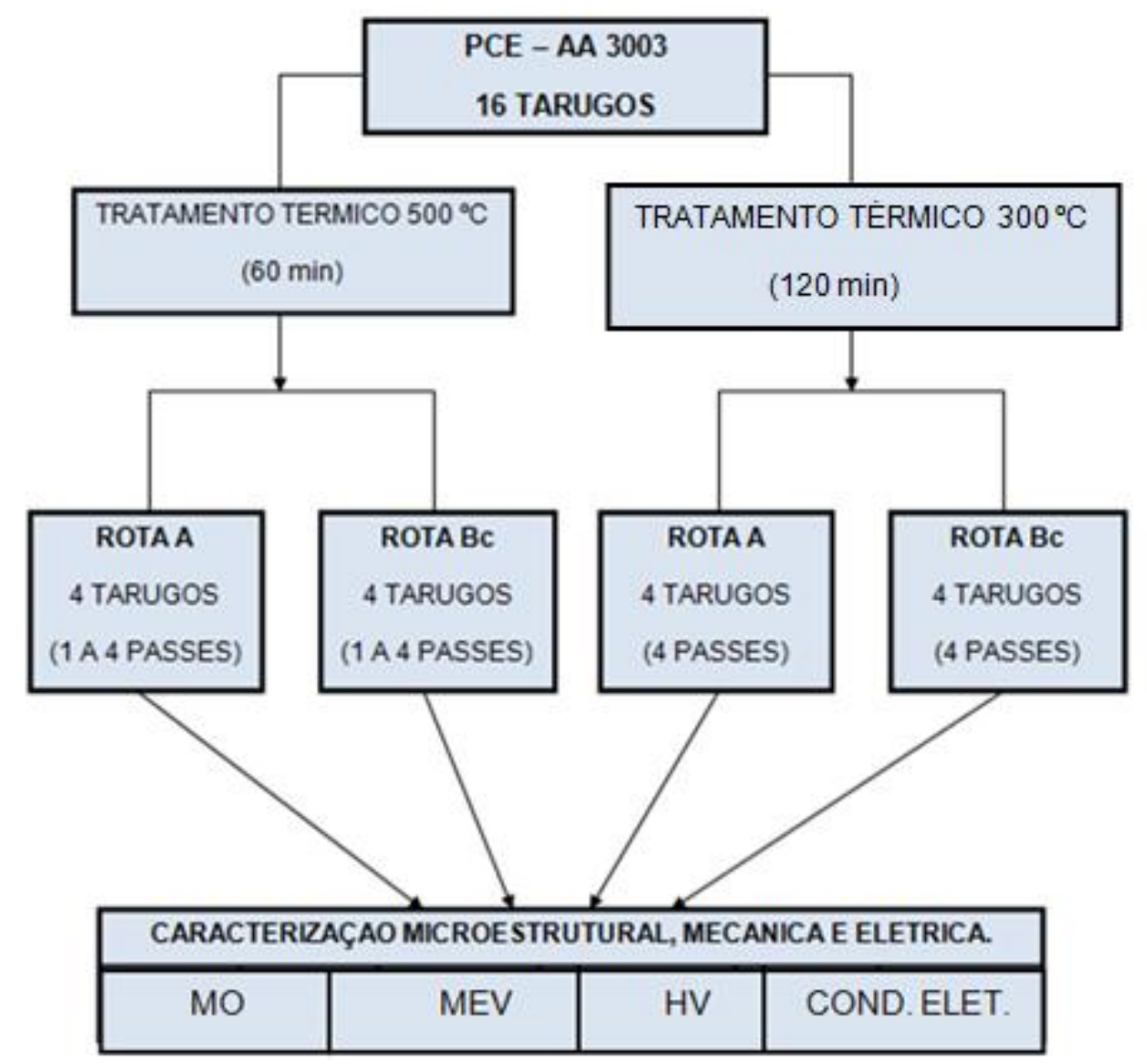

Figura 13. Esquema das etapas de caracterização da liga .AA 3003 após PCE. 


\section{RESULTADOS E DISCUSSÕES}

Os resultados foram obtidos a partir da efetuação dos procedimentos experimentais descritos nos fluxogramas das etapas, apresentados pelas Figuras 05 e 06. A pesquisa é concentrada na liga AA 3003, da qual os resultados são apresentados e discutidos. Para efeito comparativo de desempenho dos materiais das ligas escolhidas para a pesquisa e conclusão do material que melhor atinge os objetivos propostos neste estudo, são mostrados e discutidos os resultados da do trabalho sobre a liga AA 1050. (GUERRA, 2015)

Nas análises das microscopias ópticas, tomando como referência o sentido de extrusão da placa metálica, são especificados os planos normal, longitudinal e transversal, conforme indicado na Figura 14.

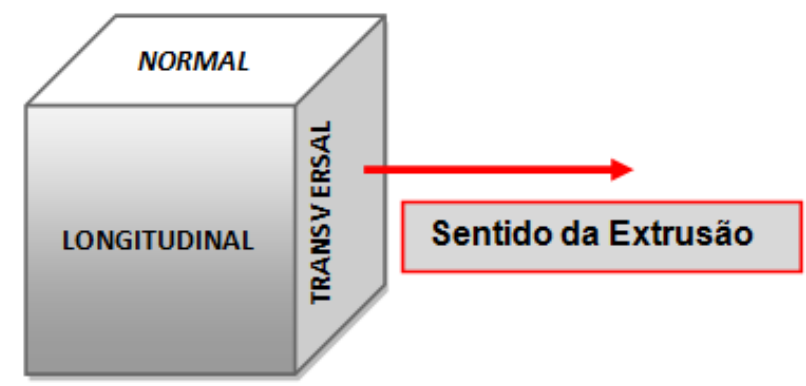

Figura 14. Sentido de extrusão das placas metálicas das ligas de alumínio $A A$ 3003 e AA 1050 cedidas pela CBA.

\subsection{Liga de Alumínio AA 3003}

5.1.1. Caracterização Microestrutural, Mecânica e Elétrica do material como recebido

\subsubsection{Microscopia Óptica (MO)}

No início dos procedimentos experimentais da liga AA 3003 o material como recebido foi submetido à análise por microscopia óptica (MO - 
500X) e a análise da micrografia de sua secção longitudinal, Figura 16, apresentou grãos alongados, efeitos gerados pelo processo de fabricação da placa, por laminação a quente, efetuada pela CBA - Companhia Brasileira de Alumínio. $O$ alongamento ocorre no final do processo Direct Chill - DC, onde após a obtenção do alumínio primário, há a formação da placa pela retração de um pistão hidráulico. Vale observar que o sentido apresentado pelos grãos foi 0

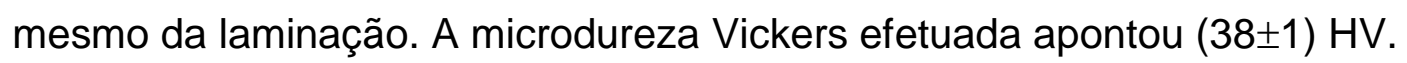

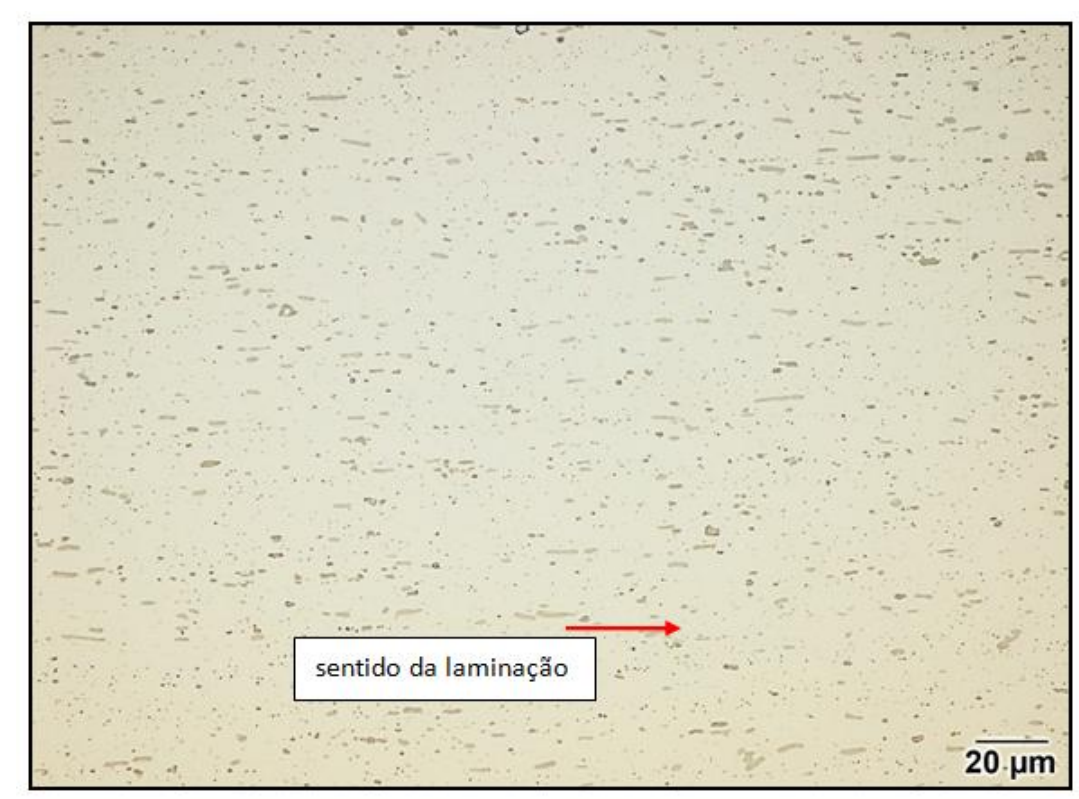

Figuras 15. Micrografia da secção longitudinal MO (500X - secção long. - meio) da liga AA 3003 (situação inicial) - material como recebido. Microdureza: $(38 \pm 1)$ HV.

\subsubsection{Espectro de Dispersão de energia (EDS) - Microscópio}

\section{Eletrônico de Varredura (MEV)}

O material como recebido foi observado pelo MEV, e o EDS, forneceu o espectro de dispersão de energia dos elementos químicos que compõem a liga AA 3003 apresentado na Figura 16. 


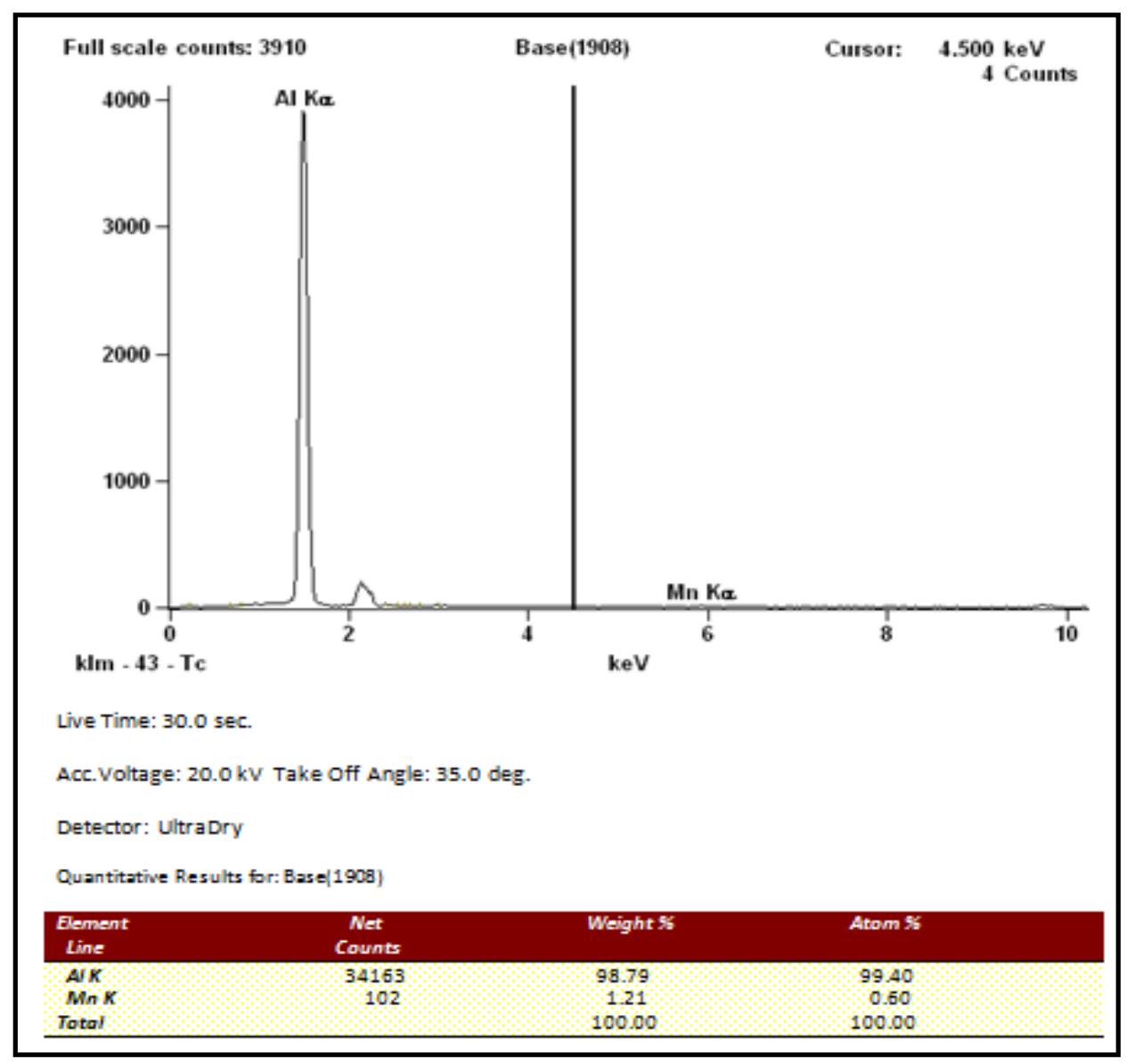

Figura 16. MEV - EDS - Espectro de dispersão de energia para a liga AA 3003.

Percebeu-se então tratar-se de um material composto praticamente de alumínio puro, mas com um percentual de manganês, 1,21 \% em peso, conforme descrito na Tabela 01. E a diferença entre os raios atômicos do Al, $\mathrm{r}_{\mathrm{Al}}=118 \mathrm{pm}$ e do $\mathrm{Mn}, \mathrm{r}_{\mathrm{Mn}}=161 \mathrm{pm}$ pode ter influenciado na difusão destes elementos nos mecanismos envolvidos no processo de PCE. Como as ligas Al$\mathrm{Mn}$, segundo a revisão da literatura, somente podem ser endurecidas por encruamento, elas são afeitas ao processo de PCE. 


\subsubsection{Determinação da Condutividade Elétrica $(\sigma)$}

A determinação da condutividade elétrica da liga AA 3003, com o material como recebido, foi realizada nos laboratórios da CBA - Companhia Brasileira do Alumínio, com o equipamento ZAPPI DC-11S kHz. Tomou-se como base o que a literatura propõe, partindo-se do conceito de resistividade de um material como a razão $\boldsymbol{\rho}$ entre o campo elétrico $\overrightarrow{\boldsymbol{E}}$ em um ponto no material resistivo e a densidade de corrente $\overrightarrow{\boldsymbol{J}}$, no ponto em questão. (HALLIDAY, 2003). Logo, a resistividade é fornecida pela expressão matemática

$$
\boldsymbol{\rho}=\frac{\boldsymbol{E}}{\boldsymbol{J}}
$$

Do S.I. - sistema internacional de unidades de medida, tiram-se

$$
\text { unidade }(\rho)=\frac{\text { unidade }(E)}{\text { unidade }(J)}=\frac{V / m}{A / m^{2}}=\frac{V}{A} \cdot m=\Omega . m
$$

Por consequência de função, a condutividade $\sigma$ é o inverso da resistividade e portanto pode ser representada pela expressão

$$
\boldsymbol{\sigma}=\frac{1}{\rho}
$$

E do sistema internacional de unidades vem:

$$
\text { unidade }(\sigma)=\frac{1}{\Omega \cdot m}=(\Omega \cdot m)^{-1}=\frac{\text { Siemens }}{m}=\frac{S}{m}
$$

Tomado historicamente (1913) como padrão de condutibilidade, o cobre (Cu) tornou-se o material referencial para os demais metais. E a condutibilidade do cobre recozido foi dado como $100 \%$ e denominado Padrão Internacional do Cobre Recozido, ou, em inglês IACS - International Annealed Copper Standard. Destarte, as unidade de condutibilidade dos materiais metálicos é medida em $\%$ IACS, ou

$$
\begin{gathered}
\text { unidade }\left(\sigma_{\text {metal }}\right)=\% \operatorname{IACS}=\%\left(\sigma_{C u}\right) \\
\text { unidade }\left(\sigma_{\text {metal }}\right) \cong \%\left(59,210^{6} \frac{\mathrm{s}}{\mathrm{m}}\right) \quad(\text { HALLIDAY, 2003) }
\end{gathered}
$$


Tabela 02. Condutividade elétrica do material - Liga AA 3003 - Material como recebido

\begin{tabular}{|c|c|}
\hline LEITURA & CONDUTIVIDADE (\% IACS) \\
\hline$\sigma_{\mathbf{1}}$ & 40,6 \\
\hline$\sigma_{2}$ & 40,8 \\
\hline$\sigma_{3}$ & 40,6 \\
\hline$\sigma_{\text {média }}$ & $40,7 \pm 0,1$ \\
\hline
\end{tabular}

\subsubsection{Caracterização Microestrutural e Mecânica do Material após Tratamento Térmico Inicial $\left(500^{\circ} \mathrm{C}-8 \mathrm{~h}\right)$, pré Prensagem por Canais Equiangulares - PCE}

Para a caracterização microestrutural das amostras da liga AA 3003 foi utilizada, no desenvolver da pesquisa, a microscopia óptica com luz polarizada que expressou em cores características do material observado. O princípio da polarização da luz para as observações em microscópio óptico foi obtido por filtros polarizadores construídos de cristais dicroicos e sulfeto de iodo-quinona dicroico, depositados sobre uma película de plástico. Esses dispositivos, específicos do microscópio, denominados filtro polarizador e analisador são os responsáveis pela ocorrência do fenômeno da polarização da luz no instrumento óptico. O primeiro polariza a luz incidente, enquanto o segundo, ajustável de 0 a $90^{\circ}$, examina a luz refletida na superfície da amostra. (CBA, 2018)

O material como recebido, logo após a sua caracterização microestrutural, foi levado a um tratamento térmico inicial que começou a $50{ }^{\circ} \mathrm{C}$, seguindo uma rampa com taxa de aquecimento de $150^{\circ} \mathrm{C} / \mathrm{h}$ até atingir a temperatura de banho de $500 \stackrel{\circ}{\circ}$. Esta temperatura de banho foi mantida por oito horas. As amostras foram então retiradas da mufla para resfriamento em ar livre. A micrografia da Figura 17, produzida pelo MO com luz polarizada, 50X, no sentido longitudinal, o mesmo da laminação, revelou os grãos alongados no 
sentido da laminação, que se deve ao processo da produção por laminação a quente do material.

O ensaio mecânico apontou a microdureza de (32 \pm 1$)$ HV, diminuída em relação ao valor referente ao material como recebido, por consequência do recozimento sofrido. A micrografia do sentido transversal também apresentou o mesmo comportamento.

5.1.2.1 Microscopia Óptica (MO) com luz polarizada do material da liga AA 3003, pós tratamento térmico inicial, pré PCE

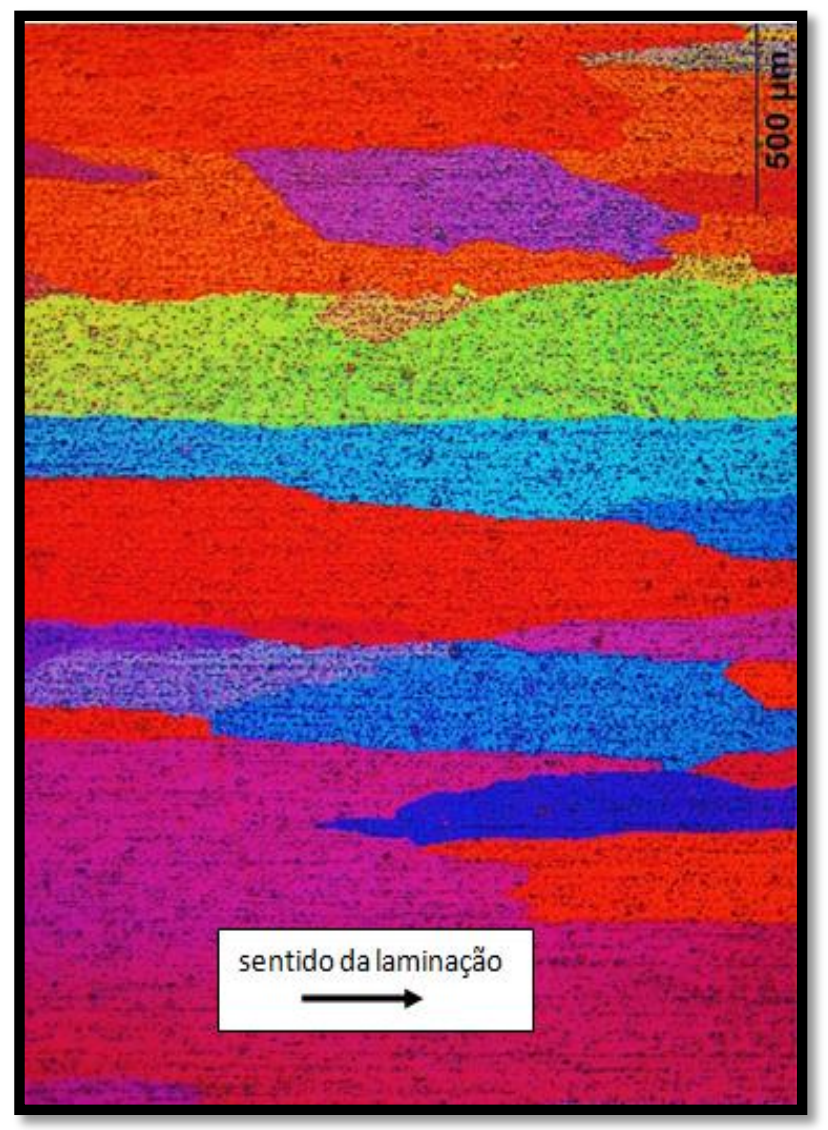

Figura 17. MO - micrografia com luz polarizada (longitudinal - 50X) da liga AA 3003 , pós tratamento térmico inicial $\left(500^{\circ} \mathrm{C}-8,0 \mathrm{~h}\right.$, após rampa de 3,0 h) - pré PCE. Microdureza $=(32 \pm 1) \mathrm{HV}$. 


\subsubsection{Caracterização Microestrutural, Mecânica e Elétrica do Material após Prensagem por Canais Equiangulares (PCE)}

\subsubsection{Microscopia Óptica (MO) com luz polarizada}

\subsection{Micrografias das amostras da liga AA 3003 prensadas} pela rota A - pré e pós recozimento

Cumprindo as etapas do fluxograma da Figura 07, o passo seguinte ao tratamento térmico inicial é a prensagem por canais equiangulares PCE e a caracterização, mecânica e por microscopia óptica, do material, pré recozimento e pós recozimento de $500 \stackrel{\circ}{\mathrm{C}}$, por 1,0 hora.

$\mathrm{Na}$ análise das micrografias (MO - 500X) apresentadas pelas Figuras 18, 19, 20 e 21 percebeu-se que após a retirada das tensões residuais pelo recozimento aplicado às amostras, houve recristalização com diminuição do tamanho de grão e aumento de dureza, conforme os resultados mostrados nos itens seguintes da pesquisa. Foram, em um primeiro momento, analisadas as micrografias das amostras que percorreram a rota $A$, com um passe $(1 A)$, dois passes $(2 A)$, três passes $(3 A)$ e quatro passes $(4 A)$.

A diminuição do tamanho de grão deveu-se ao fato de, no processo de PCE, não ter havido redução da secção transversal da amostra, o que fez com que ocorresse um acúmulo de deformação plástica, produzindo grãos com tamanhos na ordem de escala nanomética. 


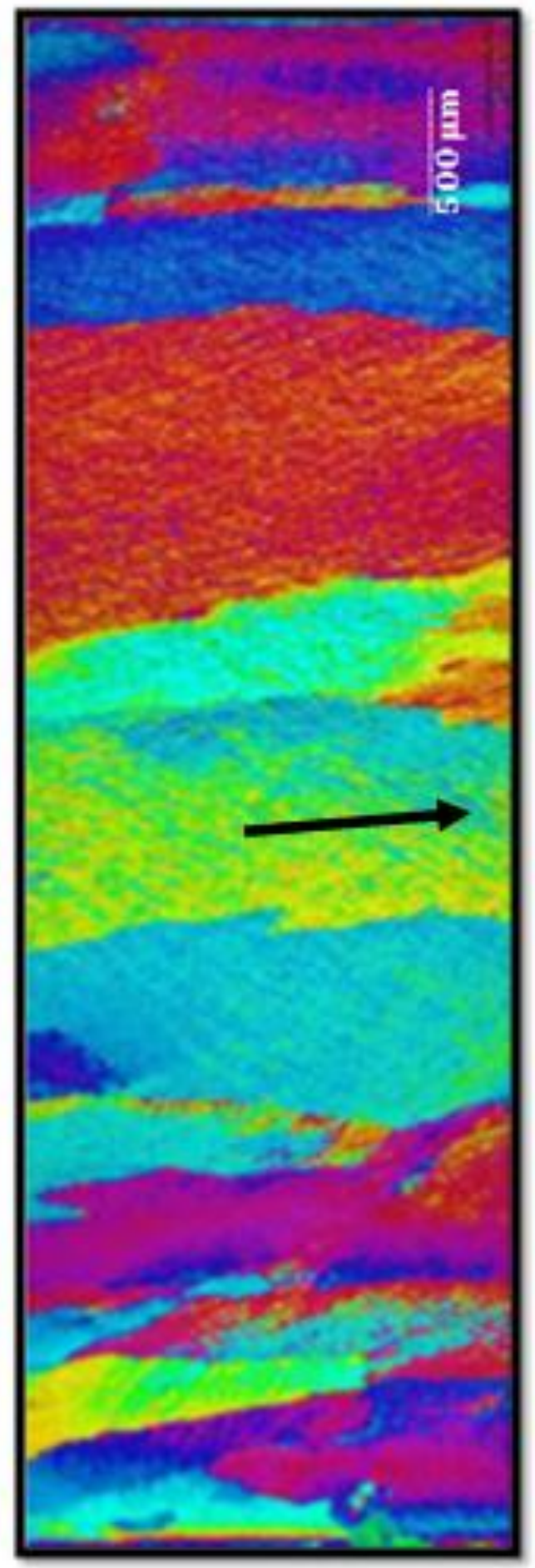

(a)

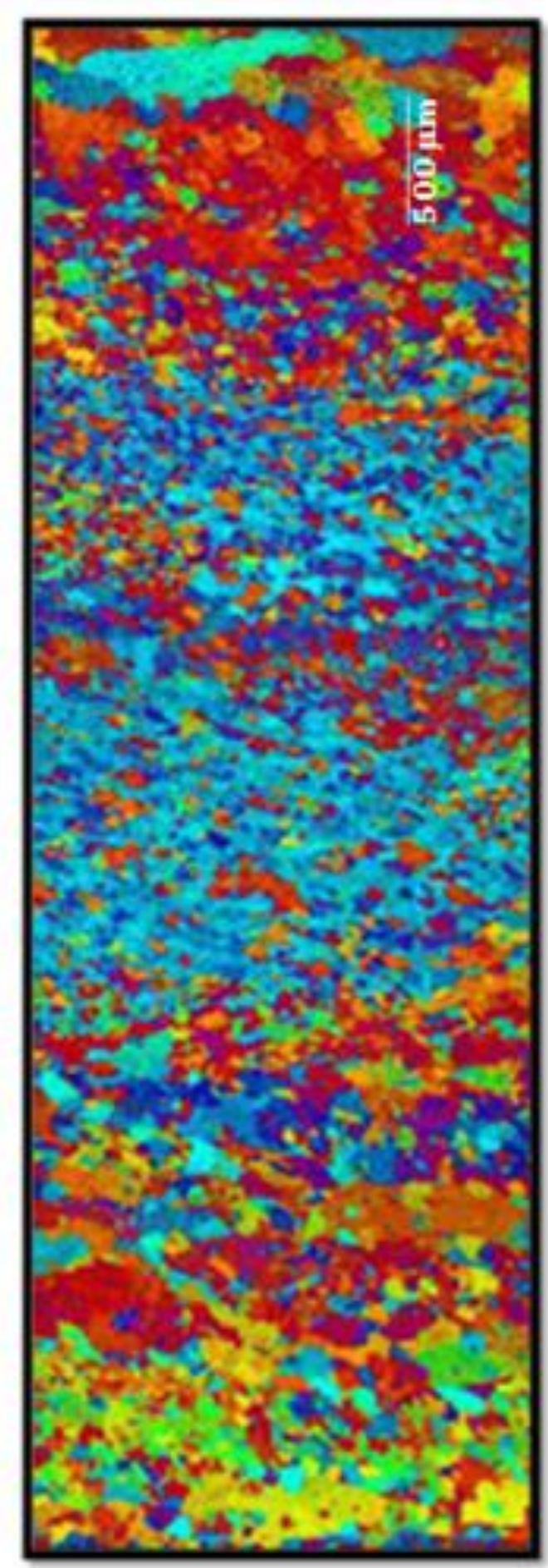

(b)

Figura 18. $M O$ - micrografia com luz polarizada (longitudinal - 500X) da liga $A A$ 3003: (a) rota A - 1A, pré recozimento, com o sentido da extrusão; (b) rota. A $1 \mathrm{~A}$, pós recozimento. 


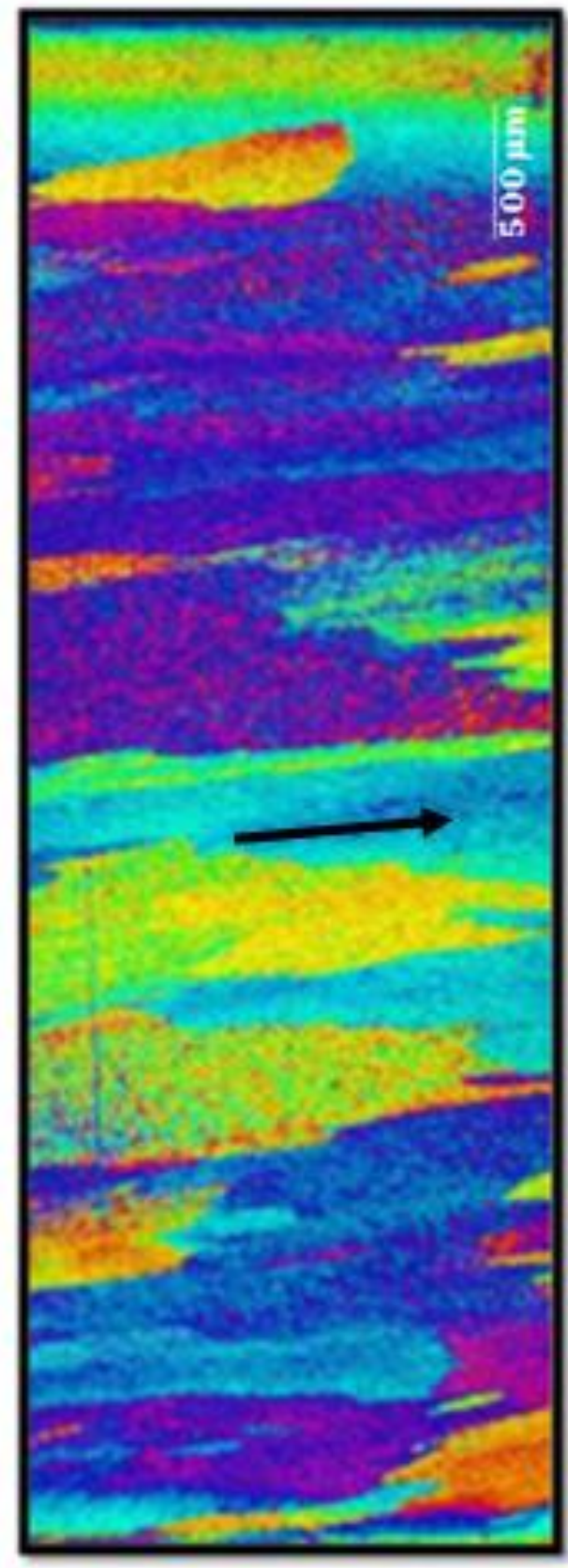

(a)

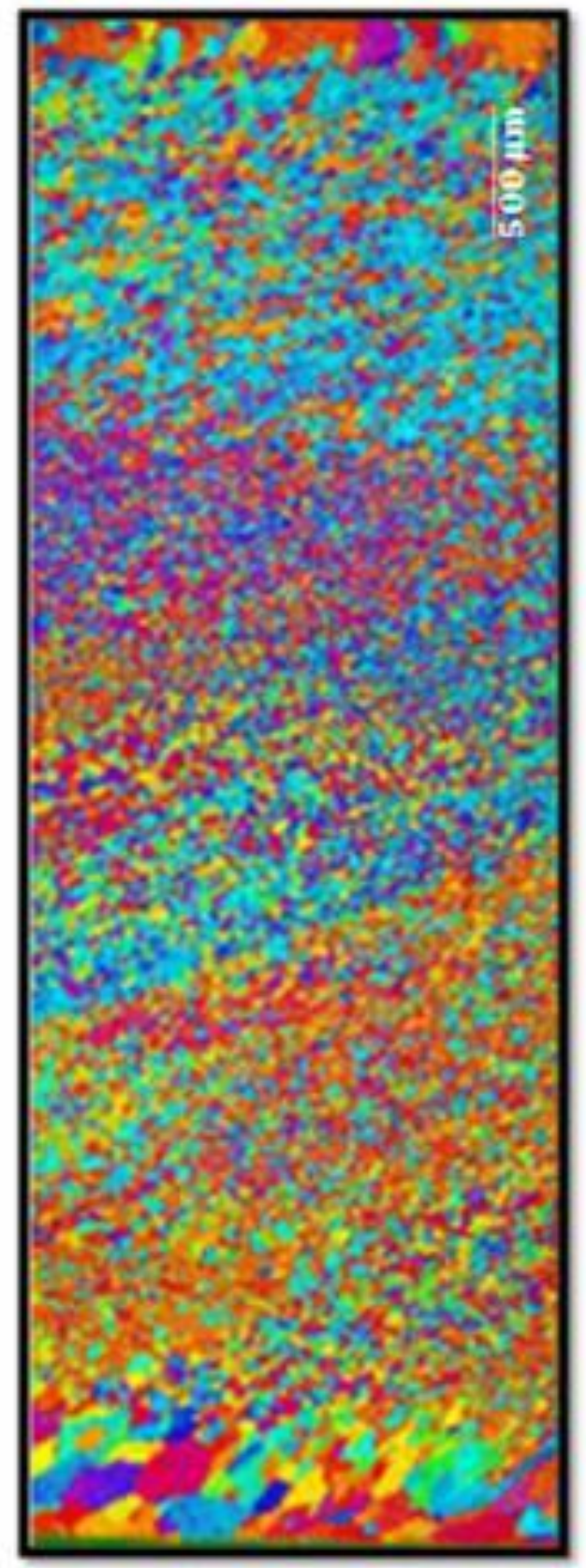

(b)

Figura 19. $\mathrm{MO}$ - micrografia com luz polarizada (longitudinal - 500X) da liga AA 3003: (a) rota $A-\mathbf{2 A}$, pré recozimento, com o sentido da extrusão; (b) rota $A-2 A$, pós recozimento. 


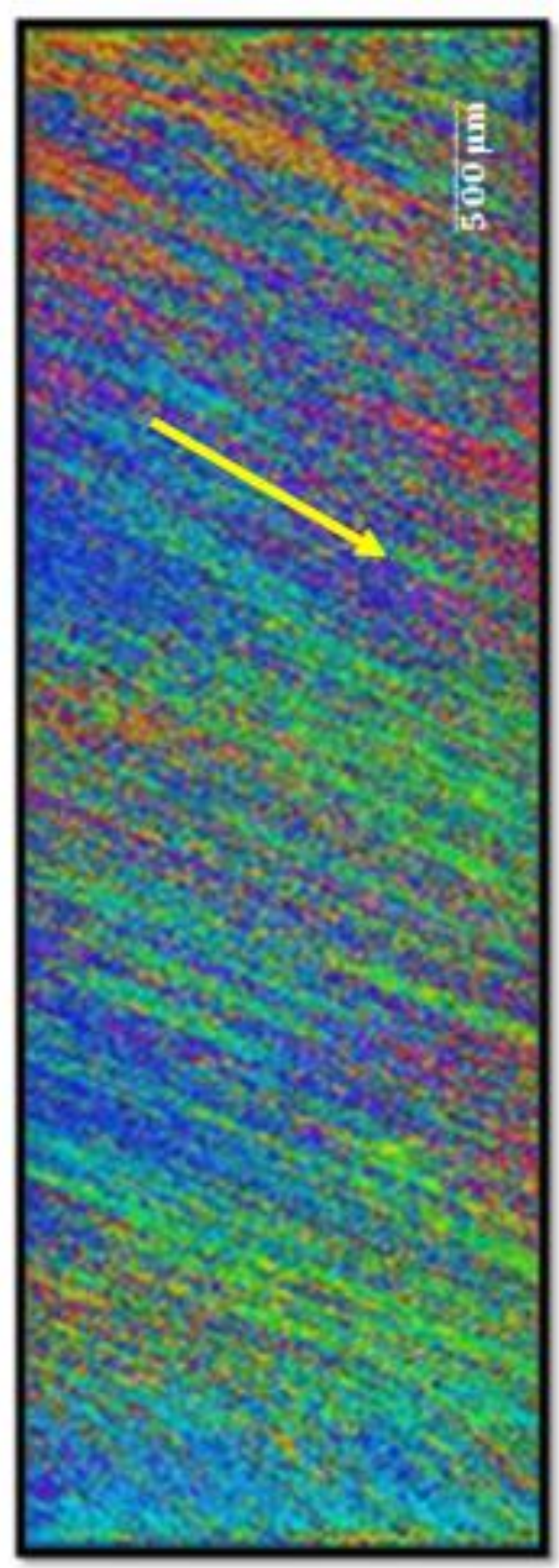

(a)

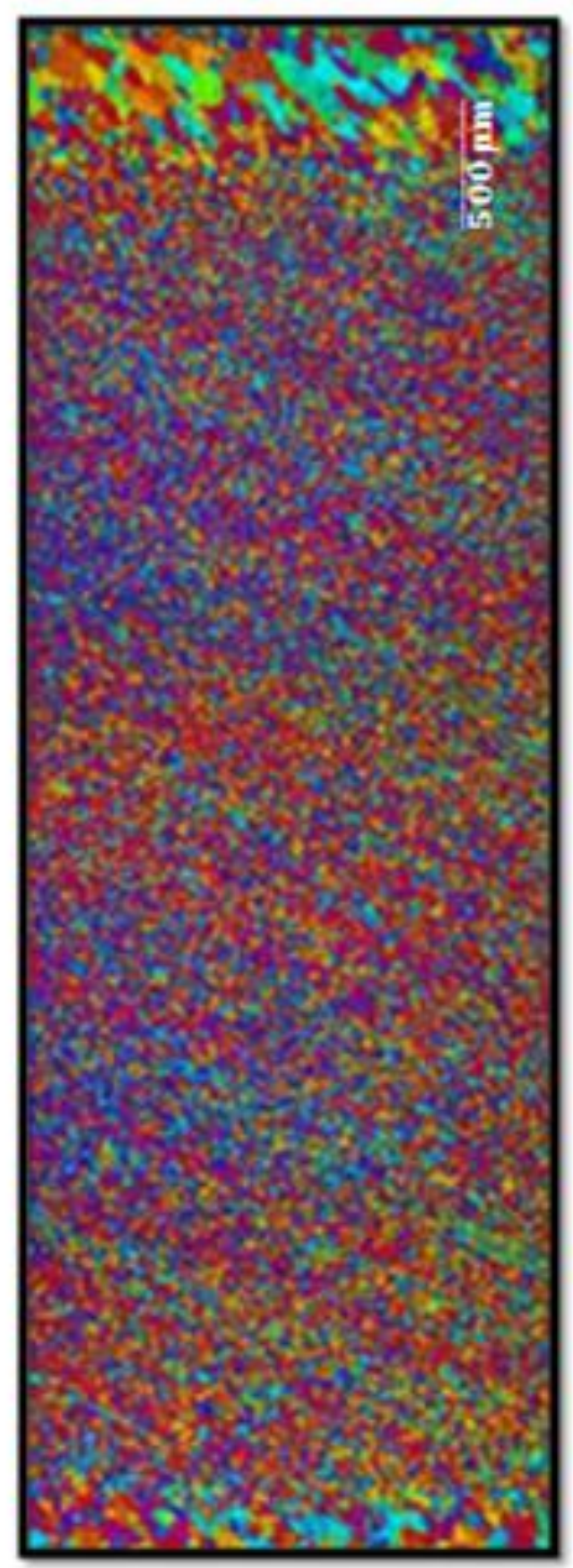

(b)

Figura 20. $M O$ - micrografia com luz polarizada (longitudinal - 500X) da liga AA 3003: (a) rota $A$ - 3A, pré recozimento, com o sentido da extrusão; (b) rota $A$ 3A, pós recozimento. 


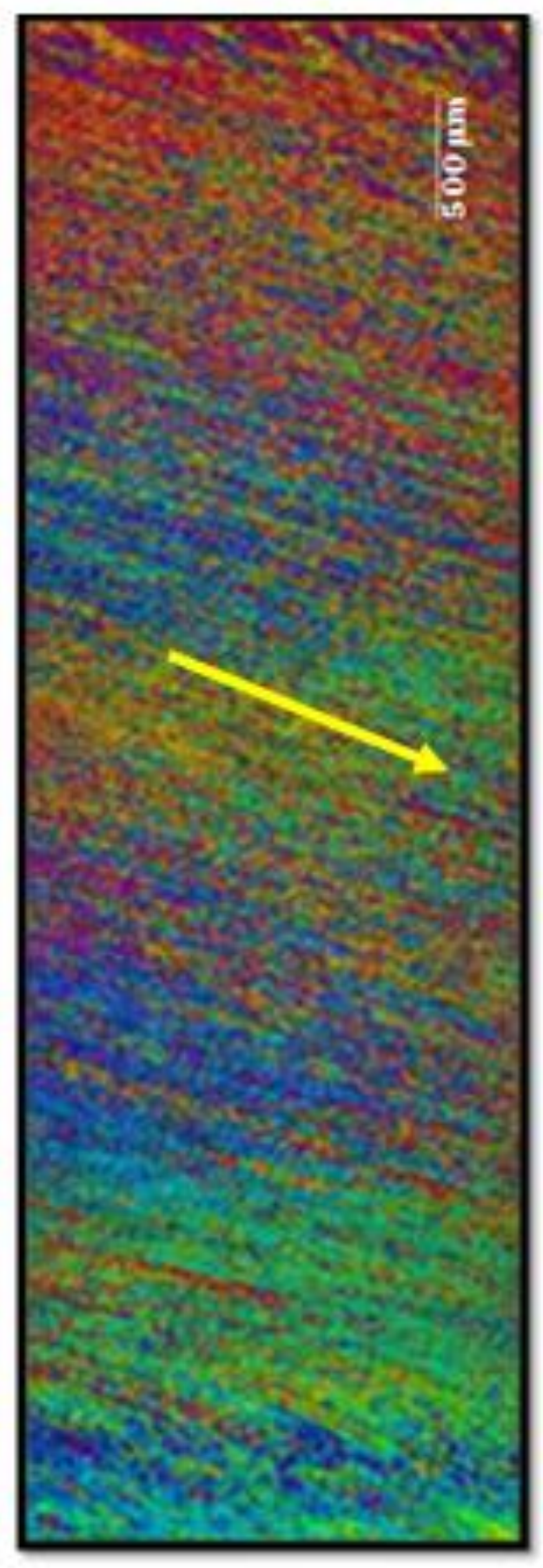

(a)

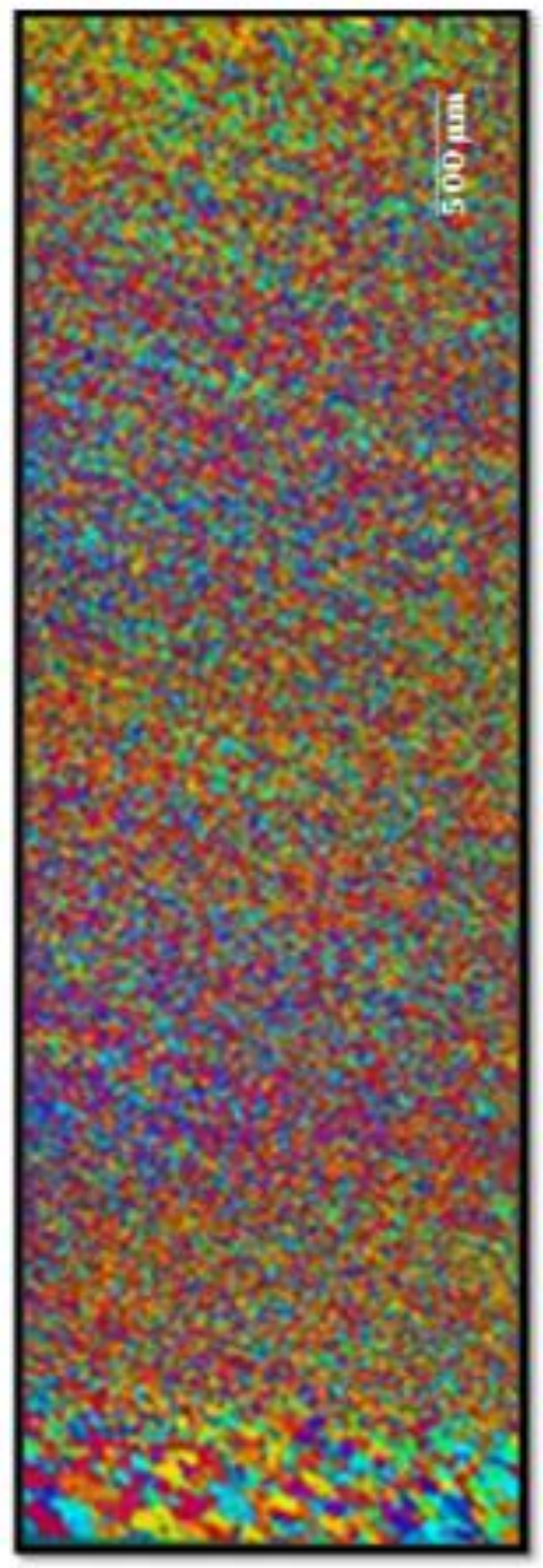

(b)

Figura 21. $M O$ - micrografia com luz polarizada (longitudinal - 500X) da liga $A A$ 3003: (a) rota $A$ - 4A, pré recozimento, com o sentido da extrusão; (b) rota $A$ 4A, pós recozimento. 
A comparação entre as micrografias à medida que a quantidade de passes aumenta, tanto antes, quanto depois do recozimento, mostrou que a diminuição do tamanho de grão está diretamente associada ao aumento de número de passes. Isto se deveu ao acúmulo de deformações sofridas pela amostra, a cada passe efetuado.

Foram observadas as bandas de deformação na direção de extrusão nas micrografias obtidas antes do recozimento, porém, não houve recristalização e, portanto, a impossibilidade de determinação do tamanho de grão ou, observação de planos de cisalhamento ou mesmo discordâncias intrínsecas ao grão que pudessem revelar subgrãos. A quantidade das citadas bandas aumenta à medida que o material sofre um maior número de passes, entretanto, mesmo com o maior número de passes proposto pela pesquisa - quatro - não foi observada a recristalização, antes do recozimento.

Observou-se ainda que o maior número de passes em cada liga, provocado pelo efetuar da operação por várias vezes, permitiu obter graus de deformação muito altos, o que melhorou as propriedades mecânicas dos materiais submetidos aos mecanismos propostos na pesquisa e associou essa melhoria à diminuição do tamanho médio de seus grãos, conforme indicado pelos resultados dos ensaios realizados.

\subsection{Micrografias das amostras da liga AA 3003 prensadas} pela rota $\mathrm{Bc}$ - pré e pós recozimento

Semelhante às observações verificadas nas análises das micrografias da rota $\mathrm{A}$, as da rota $\mathrm{Bc}(\mathrm{MO}$ - 500X), apresentadas pelas Figuras 22, 23 e 24, também mostraram que após a retirada das tensões residuais pelo recozimento aplicado às amostras, houve recristalização com diminuição o tamanho de grão e aumento de dureza. Ficaram evidenciadas ainda nas micrografias a não cristalização do material no antes do recozimento, bem como a relação entre o aumento da quantidade de bandas de deformação no sentido da extrusão e o maior número de passes a amostra do material pela matriz. 


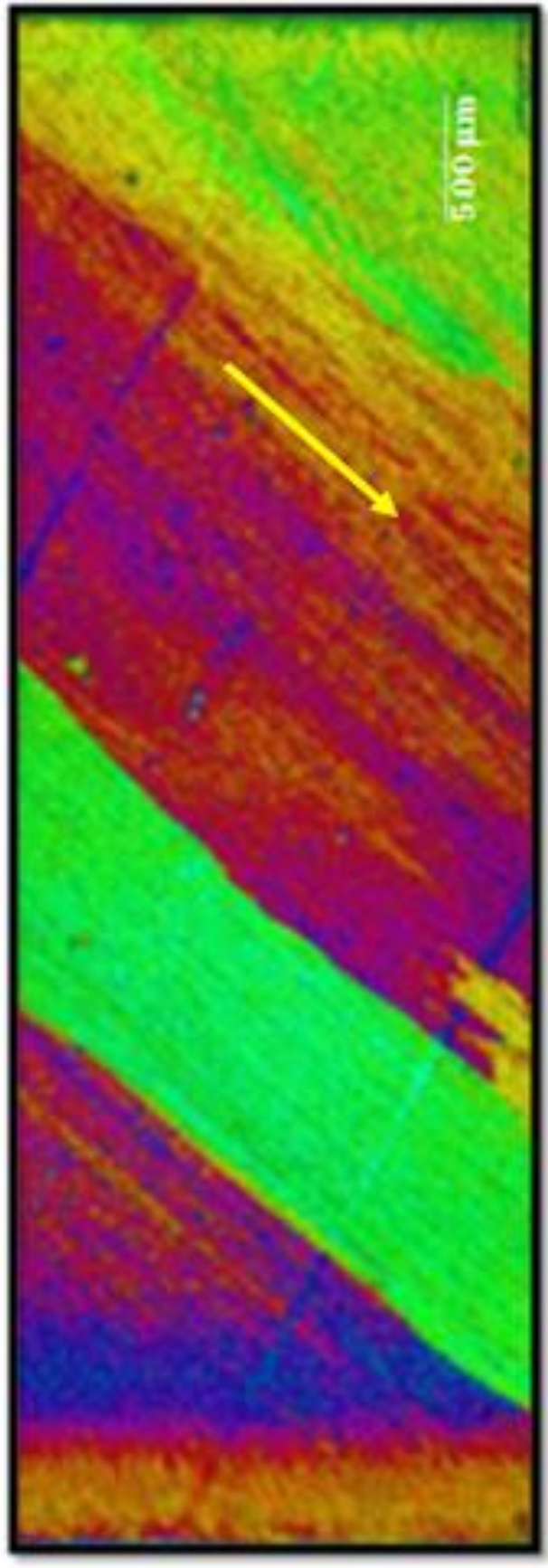

(a)

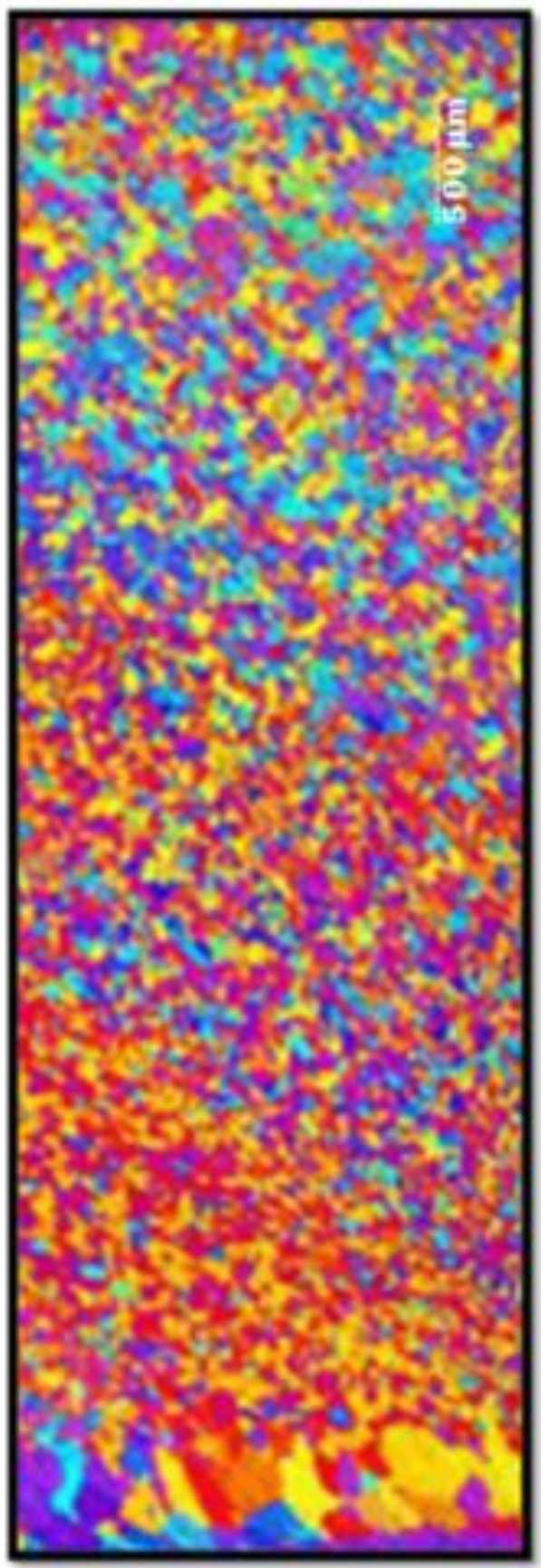

(b)

Figura 22. MO - micrografia com luz polarizada (longitudinal - 500X) da liga $A A$ 3003: (a) rota $B c-1 B c$, pré recozimento; (b) rota $B c-1 B c$, pós recozimento. 


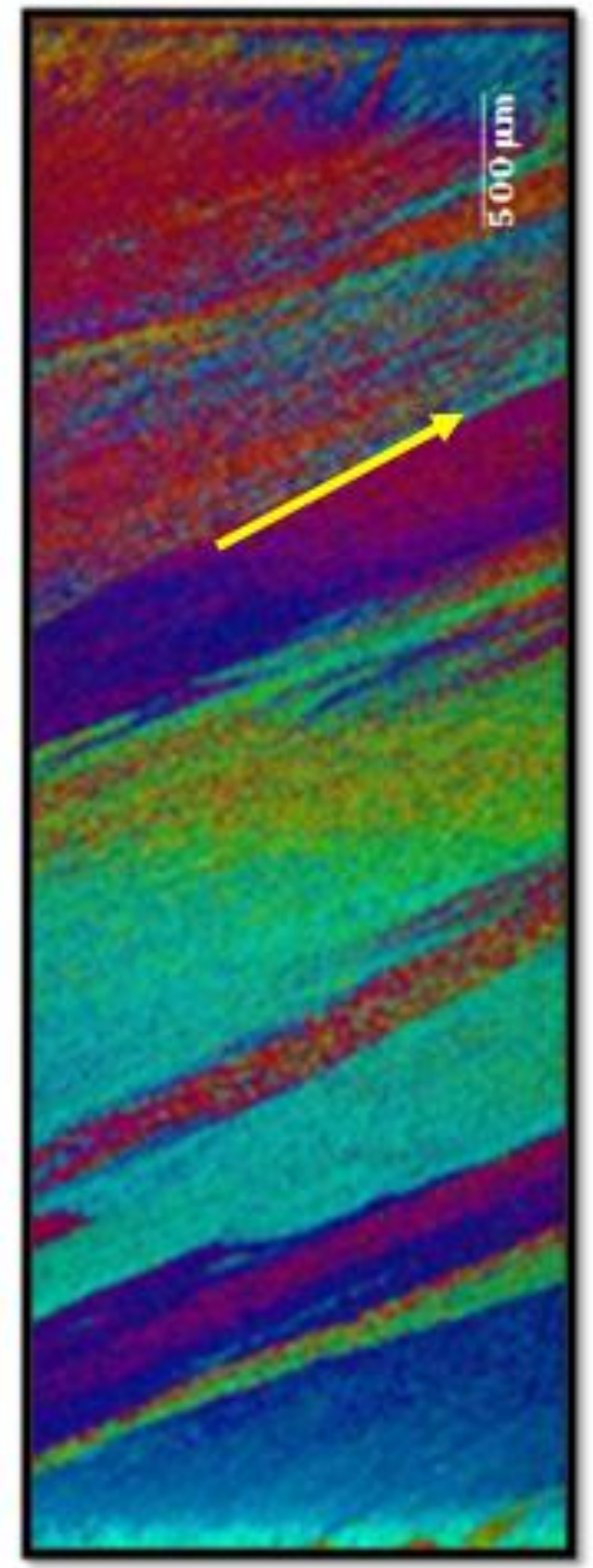

(a)

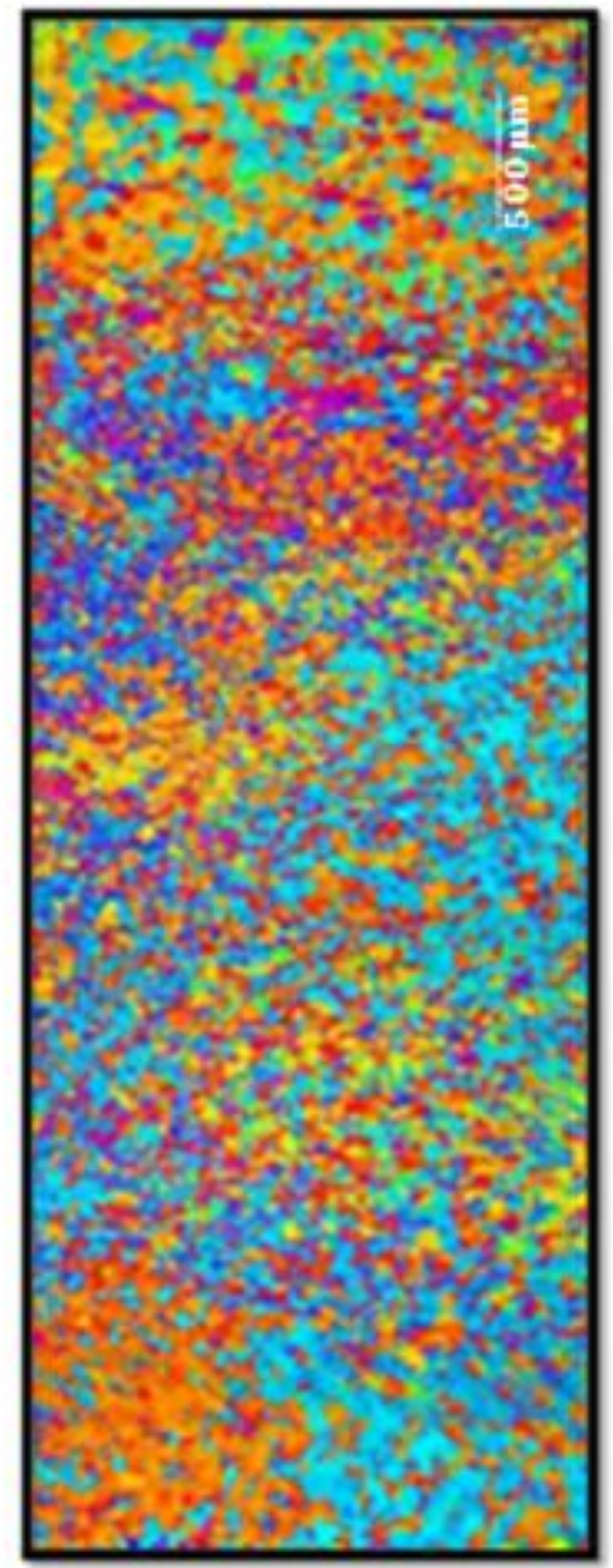

(b)

Figura 23. MO - micrografia com luz polarizada (longitudinal - 500X) da liga $A A$ 3003: (a) rota $B c-2 B c$, pré recozimento, com o sentido da extrusão; (b) rota $\mathrm{Bc}-\mathbf{2 B c}$, pós recozimento. 


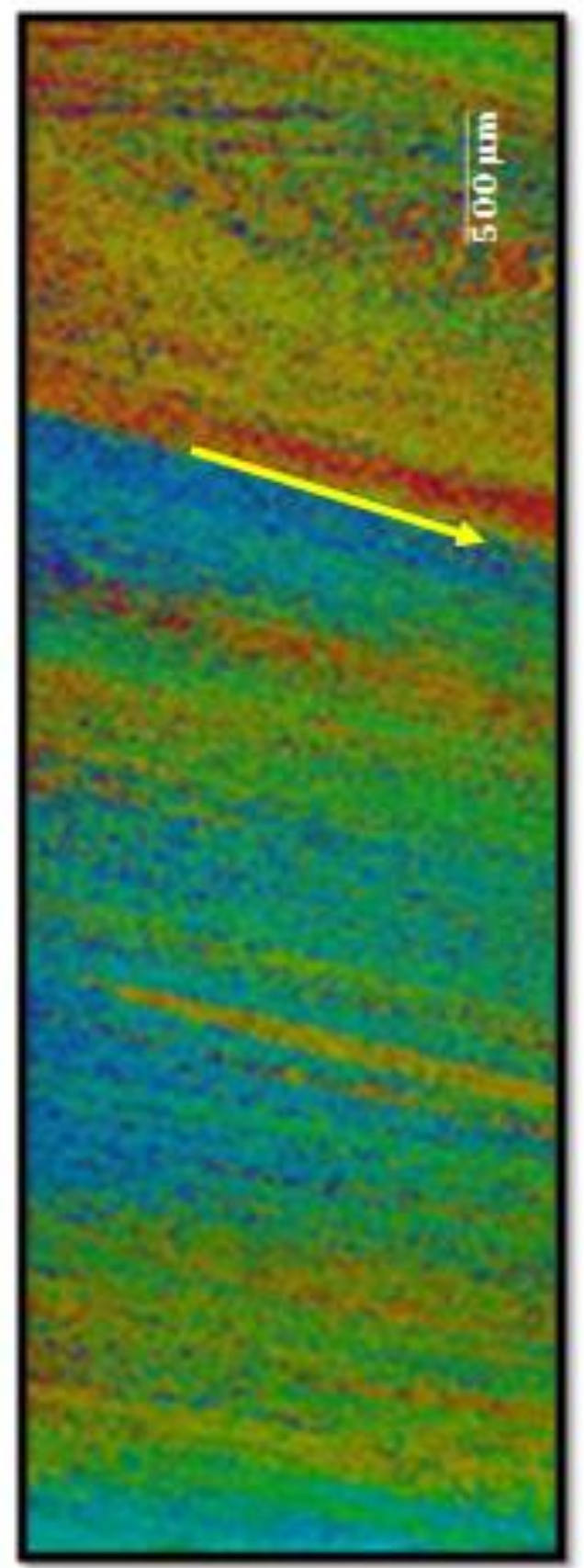

(a)

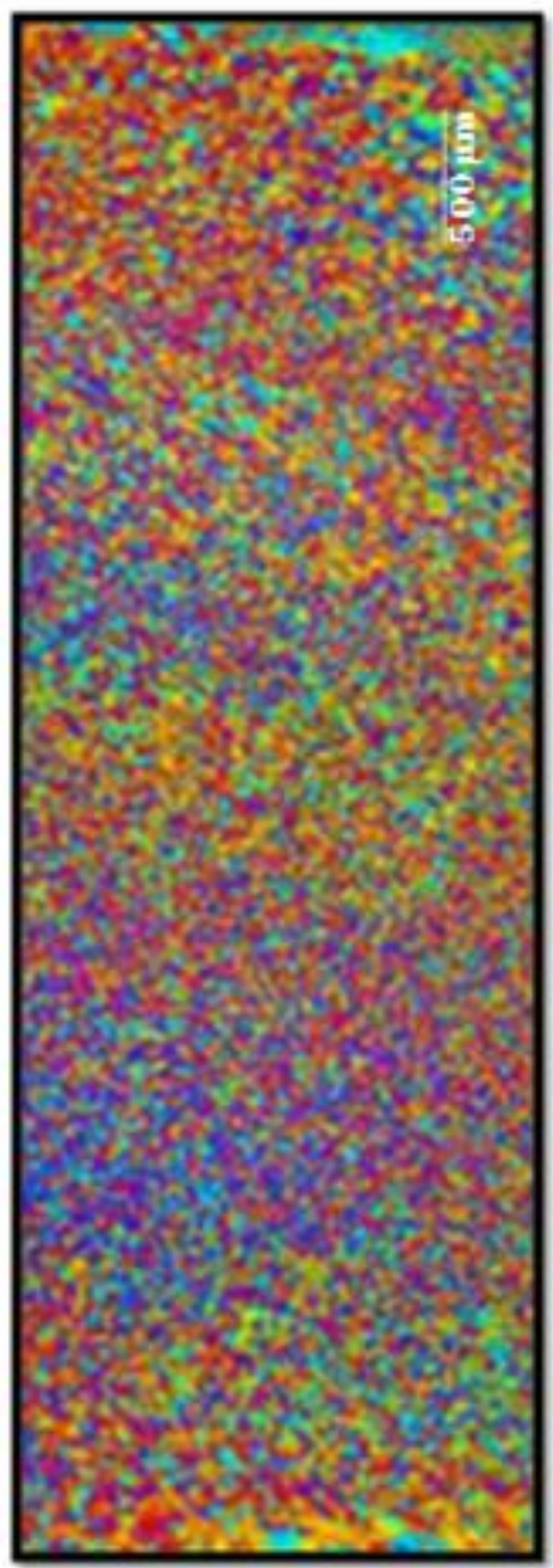

(b)

Figura 24. MO - micrografia com luz polarizada (longitudinal - 500X - liga AA 3003: (a) rota $\mathrm{Bc}-4 \mathrm{Bc}$, pré recozimento, com o sentido da extrusão; (b) rota $\mathrm{Bc}$ 4Bc, pós recozimento. 
E comparando os resultados da rota $\mathrm{A}$ com os da rota $\mathrm{Bc}$, em razão dos modos diferenciados de deformações sofridas pelas ligas nas rotas $A$ e Bc, percebeu-se menor tamanho médio de grão para um mesmo números de passes na rota $\mathrm{Bc}$, conforme mostra a Tabela 03. Isto corrobora com o registrado na literatura revista, e esta diferenciação pode explicada pela estrutura cristalina do alumínio, CFC, para a qual a literatura aponta homogeneidade microestrutural superior dada pela rota de processamento Bc, em relação às demais. Por outro lado, o manganês de um modo geral aumenta a resistência das ligas trabalhadas através da formação de fases intermetálicas. Possui baixíssima solubilidade na matriz do alumínio, cerca de $1 \%$ em peso, no caso desta pesquisa, 1,21\%, e, devida a diferença de raio e de estrutura cristalina (CCC), tende a formar segunda fase.

Tabela 03. Comparação entre micrografias com luz polarizada (longitudinal - 500X) da liga AA 3003 com iguais número de passes, porém rotas distintas - pós recozimento.

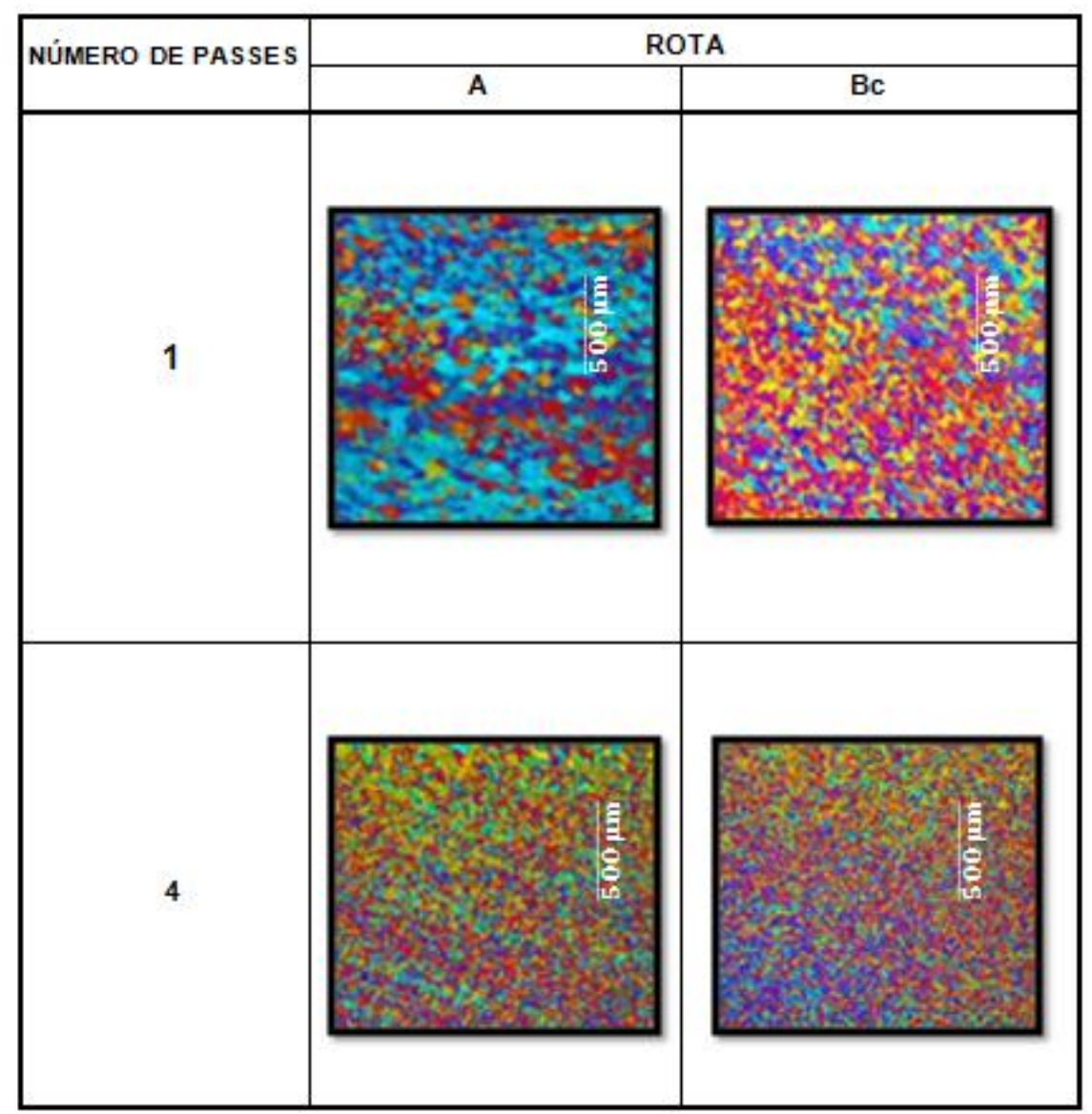




\subsubsection{Determinação do Tamanho de Grão do material da liga}

AA 3003

Para a determinação do tamanho de grão dos materiais das ligas desta pesquisa foi seguido o procedimento padrão $E$ 112-12, encontrado na American Society for Testing and Materials (ASTM, 2012 ou ABNT NBR 6000). O tamanho de grão é obtido através da contagem do número de vezes que uma linha retilínea com o comprimento conhecido padrão, linha teste, encontra contornos de grãos. Para o procedimento são definidos como "intercepto" o segmento de linha padrão que atravessa o grão e como "intersecção" o cruzamento entre a linha teste e o contorno de grão. Deseja-se o maior número de interceptos para que seja maior a precisão do método, denominado Método do Intercepto Linear de Heyn.

A análise dos valores obtidos para o diâmetro médio dos grãos, conforme Tabela 04 , ratificou as características observadas nas micrografias. Verificou-se que o maior número de passes de uma amostra provoca a diminuição do valor de seu diâmetro médio e, em considerando o mesmo número de passes de uma amostra, o percurso pela rota Bc ofereceu menores tamanhos de grão em relação à rota $A$, e foi, consequentemente, a preferencial para a obtenção de materiais com as características mecânicas pretendidas na pesquisa.

Tabela 04. Diâmetros médios dos grãos do material da liga AA 3003 obtidos pelo método de Heyn.

\begin{tabular}{|c|c|}
\hline AMOSTRA & DIÄMETRO MĖDIO $(\boldsymbol{\mu m})$ \\
\hline 1A & $53,4 \pm 0,1$ \\
\hline 2A & $27,0 \pm 0,3$ \\
\hline 3A & $27,0 \pm 0,1$ \\
\hline 4A & $22,4 \pm 0,2$ \\
\hline 1BC & $45,0 \pm 0,1$ \\
\hline 4BC & $18,9 \pm 0,2$ \\
\hline
\end{tabular}




\subsubsection{Determinação de Microdureza Vickers (HV)}

Os ensaios experimentais para a determinação da microdureza das amostras da liga AA 3003 foram realizados nos laboratórios da Companhia Brasileira de Alumínio - CBA, pelo processo Vickers. Esse processo consistiu na aplicação sobre a superfície da amostra de um penetrador com ponta de diamante na forma piramidal, com ângulos de abertura $136^{\circ}$ e base quadrada. Sobre o penetrador foram colocadas cargas determinadas e após a retirada destas cargas, as diagonais de indentação foram medidas. $O$ valor da dureza foi calculado pela relação entre a força aplicada e a área de indentação. (CHIAVERINI, 1986,2008) Os ensaios Vickers foram realizados para a micro indentação segundo a norma ASTM E-384:2016.

A análise dos valores da coluna de pré recozimento da Tabela 05 de microdureza da liga AA 3003, confirmou que o aumento do número de passes ficou associado ao aumento da resistência mecânica do material da liga. Percebeu-se ainda que a amostra que percorre a rota $\mathrm{Bc}$, como o mesmo número de passes da que percorre a rota $A$ apresentou mais resistência mecânica.

Foram esperados os valores mais reduzidos de resistência mecânica na coluna de pós recozimento por causa dos efeitos provocados pelo tipo de tratamento térmico a que foi submetido o material da liga. Entretanto, o recozimento mostrou-se necessário para diminuir as tensões internas sofridas pelo material ao longo do processo anterior de PCE e foi também eficaz para a recristalização do material, ocorrida segundo as análises micrográficas realizadas e mostradas nas Figuras 18 a 24. 
Tabela 05. Microdureza Vickers (HV) - pós prensagem por canais equiangulares - PCE - pré e pós recozimento (500 ํㅡ $-1,0$ hora).

\begin{tabular}{|c|c|c|}
\hline \multirow{2}{*}{ AMOSTRA } & \multicolumn{2}{|c|}{ MICRODUREZA VICKERS (HV) } \\
\cline { 2 - 3 } & PRE RECOZIMENTO & POS RECOZIMENTO \\
\hline 1A & $59,0 \pm 0,1$ & $30,3 \pm 0,1$ \\
\hline 2A & $60,5 \pm 0,1$ & $32,7 \pm 0,1$ \\
\hline 3A & $62,1 \pm 0,2$ & $31,9 \pm 0,1$ \\
\hline 4A & $63,8 \pm 0,1$ & $31,9 \pm 0,3$ \\
\hline 1BC & $65,5 \pm 0,1$ & $31,1 \pm 0,1$ \\
\hline 4BC & $69,1 \pm 0,2$ & $30,3 \pm 0,1$ \\
\hline
\end{tabular}

\subsubsection{Determinação da Condutividade Elétrica $(\sigma)$}

A determinação da condutividade elétrica do material da liga $A A$ 3003, pós prensagem por canais equiangulares e pós recozimento $\left(500{ }^{\circ} \mathrm{C}-1,0\right.$ hora), foi realizada nos laboratórios da empresa ZAPPITEC com o equipamento ZAPPITEC-12Z, com sensor de $5,5 \mathrm{~mm}$. Os resultados da Tabela 06 mostraram que a variação no valor de condutividade elétrica do material que percorreu a rota A foi sutil, porém de alta. O material que percorreu a rota Bc sofreu, semelhantemente, variação de alta em sua condutividade elétrica, mas com valores acima daqueles percebidos no material da rota $A$. Não obstante a magnitude dos valores eles podem indicar que 0 material submetido a deformações mais intensas apresentou maiores valores de condutividade elétrica.

Ao comparar os resultados da Tabela 02, do material como recebido, com os da Tabela 06 percebeu-se que o material que percorreu a rota $A$, acrescentou um percentual de $13 \%$ em sua condutividade elétrica e o que percorreu a rota $\mathrm{Bc}$ apresentou um aumento de $14,7 \%$ na condutividade. A 
diferença entre os percentuais pode corroborar com a percepção da relação direta entre a intensidade de deformação sofrida e a condutividade elétrica.

Tabela 06. Condutividade elétrica do material - Liga AA 3003 - pós prensagem por canais equiangulares - PCE - pós recozimento (500 ํㅡ - 1,0 hora).

\begin{tabular}{|c|c|c|c|c|c|}
\hline \multirow{2}{*}{ AMOSTRA } & \multicolumn{5}{|c|}{ CONDUTIVIDADE (\% IACS) } \\
\cline { 2 - 6 } & $\boldsymbol{\sigma}_{\mathbf{1}}$ & $\boldsymbol{\sigma}_{\mathbf{2}}$ & $\boldsymbol{\sigma}_{\mathbf{3}}$ & $\boldsymbol{\sigma}_{\mathbf{4}}$ & $\boldsymbol{\sigma}_{\text {média }}$ \\
\hline 1A & 45,5 & 45,3 & 45,6 & 45,9 & $45,6 \pm 0,3$ \\
\hline 2A & 45,6 & 46,0 & 45,4 & 45,7 & $45,7 \pm 0,3$ \\
\hline 3A & 46,1 & 46,0 & 46,0 & 43,3 & $46,1 \pm 0,1$ \\
\hline 4A & 46,5 & 46,3 & 46,5 & 47,0 & $46,6 \pm 0,5$ \\
\hline \hline 1Bc & 45,2 & 46,3 & 46,0 & 45,8 & $45,8 \pm 0,5$ \\
\hline 2Bc & 46,9 & 47,0 & 46,9 & 47,1 & $47,0 \pm 0,1$ \\
\hline 4Bc & 47,2 & 47,4 & 47,3 & 46,7 & $47,2 \pm 0,3$ \\
\hline
\end{tabular}

5.1.4. Caracterização Microestrutural, Mecânica e Elétrica do Material - pós Prensagem por Canais Equiangulares (PCE) - pós Tratamento Térmico Posterior (300 $\stackrel{\circ}{C}-2,0$ horas)

\subsubsection{Microscopia Óptica (MO)}

Após a submissão dos corpos de prova do material da liga AA 3003 ao processo de prensagem por canais equiangulares, um lote dos tarugos que sofreram 4 passagens pela rota $A$ e outro dos tarugos que sofreram 4 passagens pela rota $B c$ foram separados para um tratamento térmico posterior ( $300{ }^{\circ} \mathrm{C}-2,0$ horas) para a pesquisa do comportamento do material em condições diferentes daquela do recozimento ( $500 \stackrel{\circ}{\circ}-1,0$ hora). Estas amostras foram caracterizadas microestrutural, mecânica e eletricamente, conforme o fluxograma da Figura 06. 


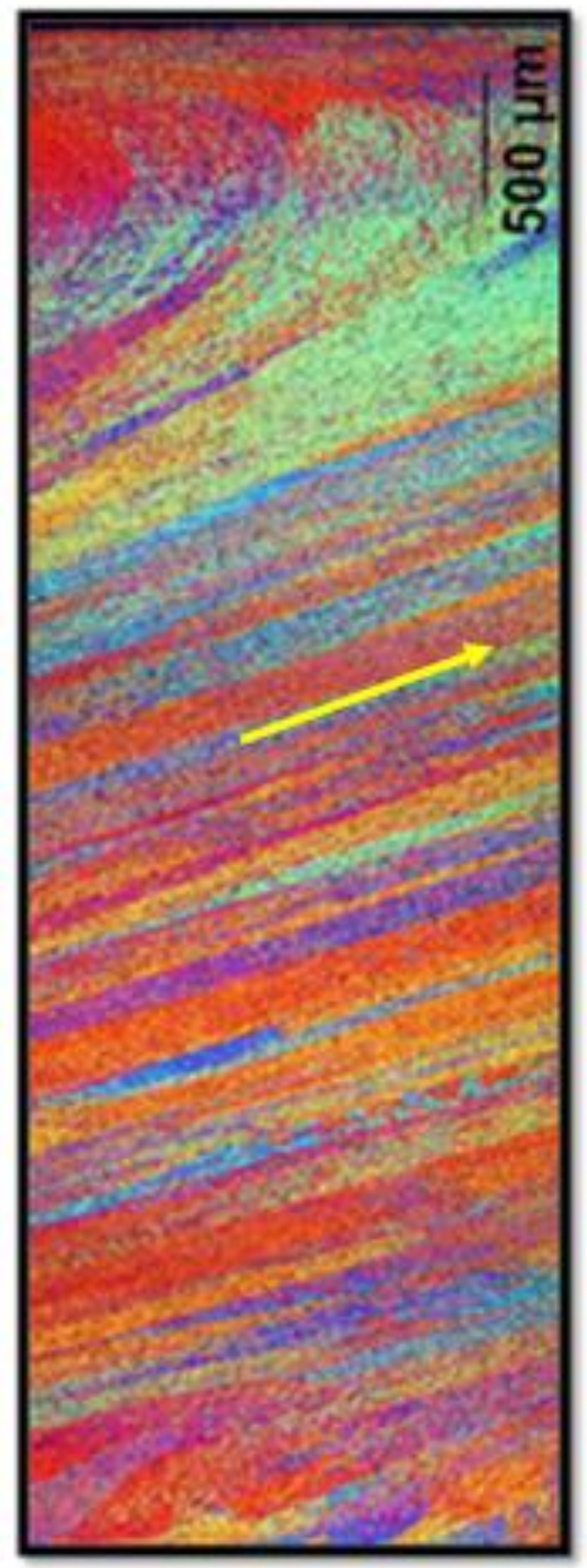

Figura 25. MO - micrografia com luz polarizada (longitudinal - 500X - liga AA 3003: rota $A-4 A$, pós $P C E$, pós tratamento térmico posterior $\left(300{ }^{\circ} \mathrm{C}-2,0\right.$ horas). Com o sentido da extrusão. 


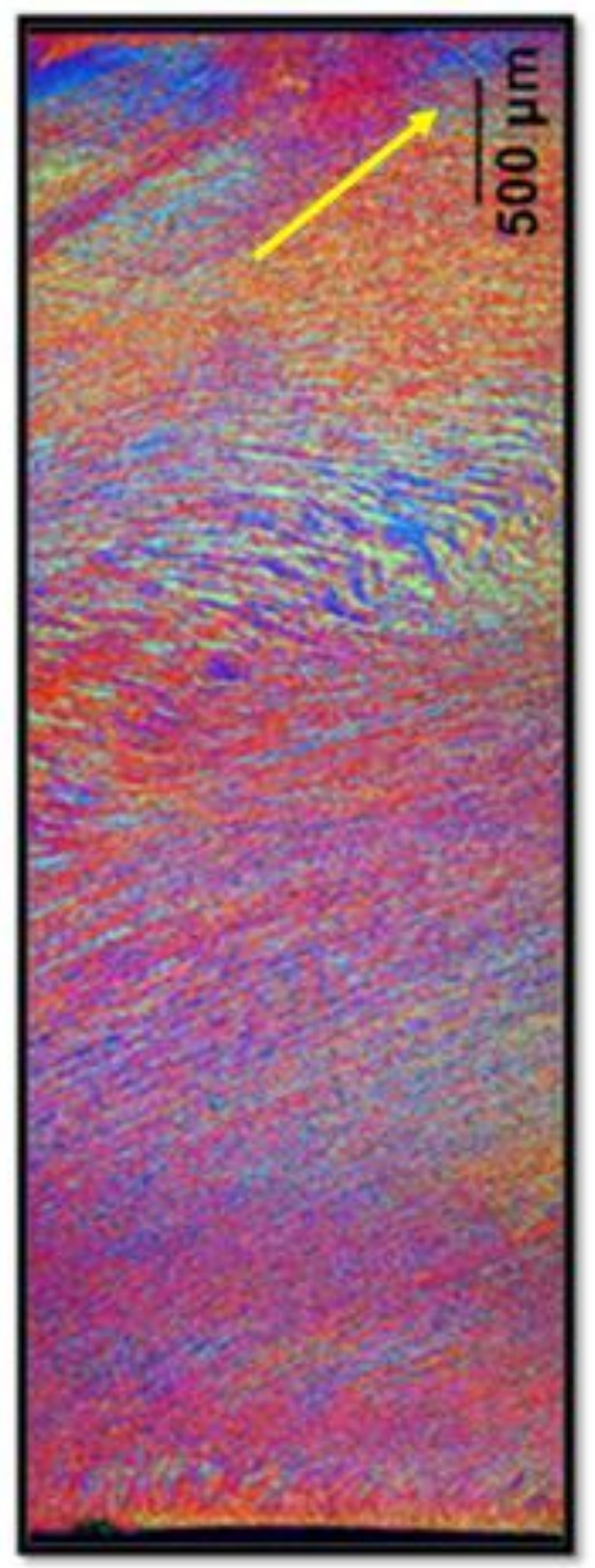

Figura 26. MO - micrografia com luz polarizada (longitudinal - 500X - liga AA 3003: rota $\mathrm{Bc}-\mathbf{4 B c}$, pós PCE, pós tratamento térmico posterior $\left(300^{\circ} \mathrm{C}-2,0\right.$ horas). Com o sentido da extrusão. 
A análise das micrografias dos materiais das amostras da liga $A A$ 3003 submetidas ao processo de prensagem por canais equiangulares e ao tratamento térmico posterior (300 ${ }^{\circ} \mathrm{C}-2,0$ horas) indicou não ser está a temperatura que promove a recristalização do material. As micrografias, tanto para o material submetido à prensagem pela rota $A$, quanto ao que cumpriu a rota $\mathrm{Bc}$, apresentaram bandas de deformação na mesma direção da extrusão. A micrografia da rota $B c$ apresentou maior quantidade de bandas com larguras bem menores do que as apresentadas pela micrografia da rota A. Esta, apresentou bandas mais marcadas e com nitidez da direção, entretanto, em nenhuma das micrografias foi possível determinar tamanho de grão, nucleação ou discordâncias que mostrassem subgrãos. Possivelmente observações realizadas através de microscópio eletrônico de transmissão (MET) possam indicar mais detalhes imperceptíveis por microscopia óptica.

As micrografias ora analisadas, das Figuras 25 e 26, podem ser comparadas às obtidas antes do recozimento do material ( $500^{\circ} \mathrm{C}-1,0$ hora), logo após à prensagem por canais equiangulares, Figuras 18 a 24. Resultados muito semelhantes foram obtidos quando, sem o recozimento para a retirada de tensões geradas pelo processo de prensagem por canais equiangulares, as micrografias mostraram o material, tanto o que cumpriu a rota $\mathrm{A}$, quanto o submetido à rota $\mathrm{Bc}$, sem a apresentação de recristalizações.

\subsubsection{Determinação de Microdureza Vickers (HV)}

Os corpos de prova submetidos ao tratamento térmico posterior foram os recém saídos do processo de prensagem por canais equiangulares, ainda, portanto, com as tensões residuais das deformações intensas sofridas, tanto pelo percurso da rota $\mathrm{A}$, quanto mais pelo percurso da rota $\mathrm{Bc}$. $\mathrm{A}$ análise dos resultados da Tabela 07 , do tratamento térmico aplicado, indica que 0 material sofreu queda em sua resistência mecânica de aproximadamente 12,9\% se percorreu a rota $\mathrm{A}$ e de aproximadamente $18,7 \%$ se percorreu a rota $\mathrm{Bc}$. Percebeu-se então que o percentual de perda na resistência mecânica é diretamente proporcional à intensidade da deformação sofrida pelo material. Porém, as micrografias por luz polarizadas mostraram não ter sido esse 
tratamento térmico, (300 ${ }^{\circ} \mathrm{C}-2,0$ horas), eficaz para a recristalização do material, tal qual ocorreu no recozimento $\left(500^{\circ} \mathrm{C}-1,0\right.$ hora) aplicado a outros lotes da liga AA 3003, conforme mostraram os resultados registrados na Tabela 05 , com as recristalizações apresentadas pelas Figuras 18 a 24.

Tabela 07. Microdureza Vickers (HV) - pós prensagem por canais equiangulares - PCE - pós tratamento térmico posterior (300 ํ $-2,0$ hora) .

\begin{tabular}{|c|c|c|}
\hline \multirow{2}{*}{ AMOSTRA } & \multicolumn{2}{|c|}{ MICRODUREZA VICKERS (HV) } \\
\cline { 2 - 3 } & PRĖ TT POSTERIOR & POS TT POSTERIOR \\
\hline 4A & 62,1 & 54,1 \\
\hline 4Bc & 69,1 & 56,2 \\
\hline
\end{tabular}

\subsubsection{Determinação da Condutividade Elétrica $(\sigma)$}

A condutividade elétrica do material da liga AA 3003 após a prensagem por canais equiangulares e tratamento térmico posterior (300 ${ }^{\circ} \mathrm{C}-2,0$ hora), com resultados na Tabela 08 , comportou-se, em relação às variações de valores, de forma muito semelhante ao percebido na Tabela 06. Entretanto os valores médios tanto para o material que percorreu a rota $A$, quanto para 0 material que percorreu a rota $\mathrm{Bc}$, com os mesmos números de passes, mantiveram-se mais baixos na Tabela 08, possivelmente indicando que a não recristalização do material foi decisiva para a determinação de valores de sua condutividade elétrica.

Observou-se, porém, que por já ter sofrido a prensagem por canais equiangulares, as deformações impostas ao material, aliadas ao tratamento térmico posterior (300 $\stackrel{\circ}{-}-2,0$ hora), pode ter sido um fator importante no aumento da condutividade elétrica do material neste ponto dos procedimentos experimentais, em relação ao material como recebido. 
Tabela 08. Condutividade elétrica do material - Liga AA 3003 - pós prensagem por canais equiangulares - PCE - pós tratamento térmico posterior $\left(300^{\circ} \mathrm{C}-2,0\right.$ hora).

\begin{tabular}{|c|c|c|}
\hline \multirow{2}{*}{ LEITURA } & \multicolumn{2}{|c|}{ CONDUTIVIDADE (\% IACS) } \\
\cline { 2 - 3 } & $4 \mathrm{~A}$ & $4 \mathrm{Bc}$ \\
\hline$\sigma_{1}$ & 45,8 & 46,7 \\
\hline$\sigma_{2}$ & 46,8 & 46,2 \\
\hline$\sigma_{3}$ & 45,9 & 46,5 \\
\hline$\sigma_{4}$ & 46,0 & 46,4 \\
\hline$\sigma_{\text {média }}$ & $45,9 \pm 0,5$ & $46,5 \pm 0,2$ \\
\hline
\end{tabular}

\subsection{Liga de Alumínio AA 1050}

\subsubsection{Caracterização Microestrutural, Mecânica e Elétrica do material como recebido}

\subsubsection{Microscopia Óptica (MO)}

Os procedimentos experimentais da liga AA 1050 seguiram as etapas mostradas no fluxograma da Figura 05 e as micrografias ópticas foram analisadas tomando igualmente como referência o sentido de extrusão da placa metálica, onde foram especificados os planos normal, longitudinal e transversal, segundo indicados na Figura 14.

Após o recebimento da placa metálica da liga AA 1050, produzida por laminação a quente pela Companhia Brasileira do Alumínio - CBA, ela foi identificada pela categoria "material como recebido" e caracterizada microestrutural, mecânica eletricamente. Primeiramente foi submetida à microscopia óptica, sob três aumentos diferentes 50X, 100X e 200X, com ponto de vista para a secção longitudinal, conforme indica a Figura 27.

A análise das micrografias do material como recebido, tanto da secção longitudinal, quanto da secção transversal apresentada na Figura 28, 
apresentaram grãos alongados, na mesma direção da laminação. O alongamento dos grãos deveu-se ao efeito da produção da placa por laminação efetuada a quente. Nessa produção usou-se o processo Direct Chill (DC), que consiste na passagem do metal líquido por um molde onde é refrigerado. A formação da placa é dada pela retração de um pistão hidráulico e sua espessura é dada pelo curso do pistão que se desloca verticalmente. A passagem do material sob a ação desse pistão provoca o alongamento de seus grãos. (CBA, 2017)
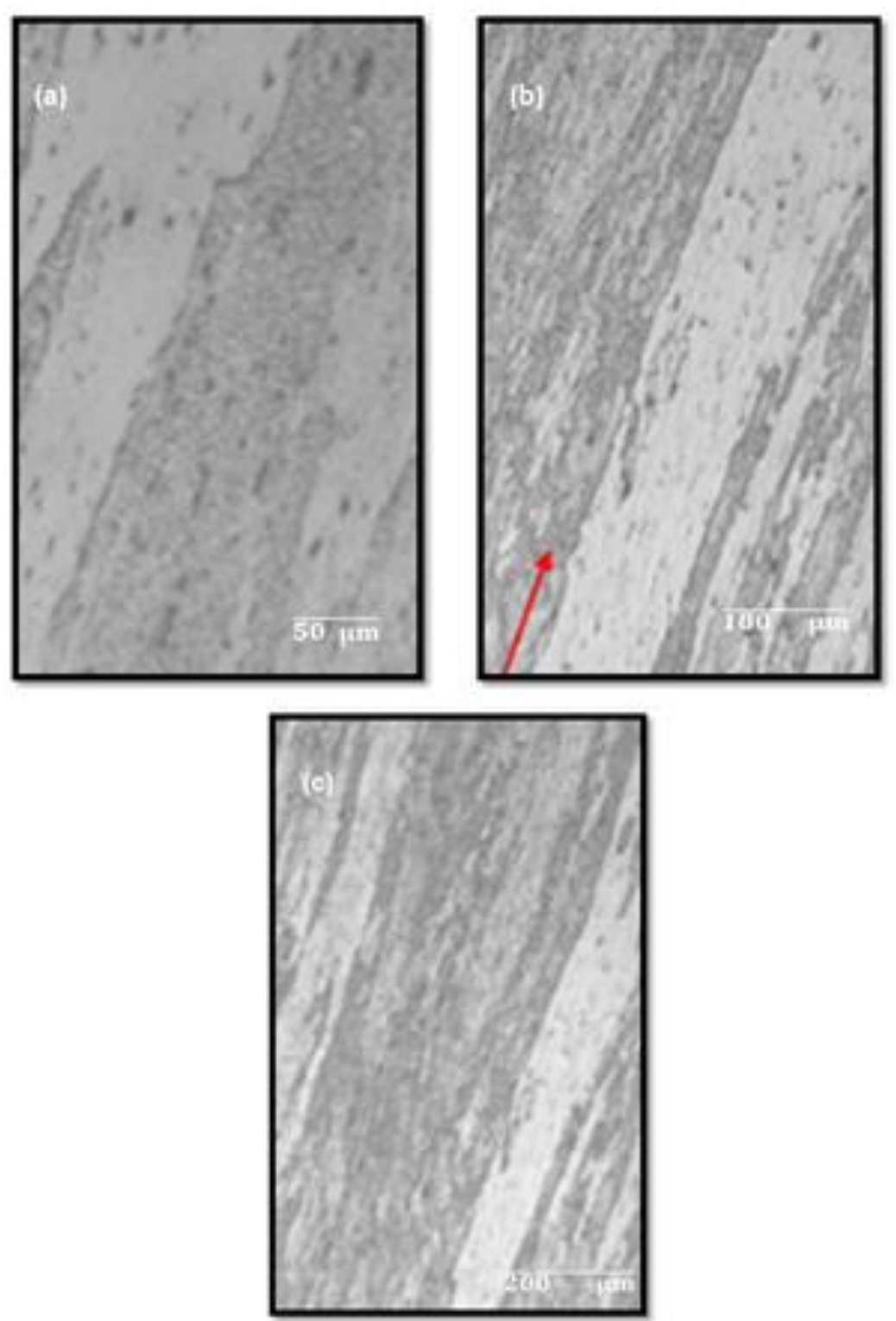

Figura 27. Micrografias da secção longitudinal da liga AA 1050 - material como recebido: (a) aumento 50X; (b) aumento 100X, com o sentido da extrusão; (c) aumento 200X. 

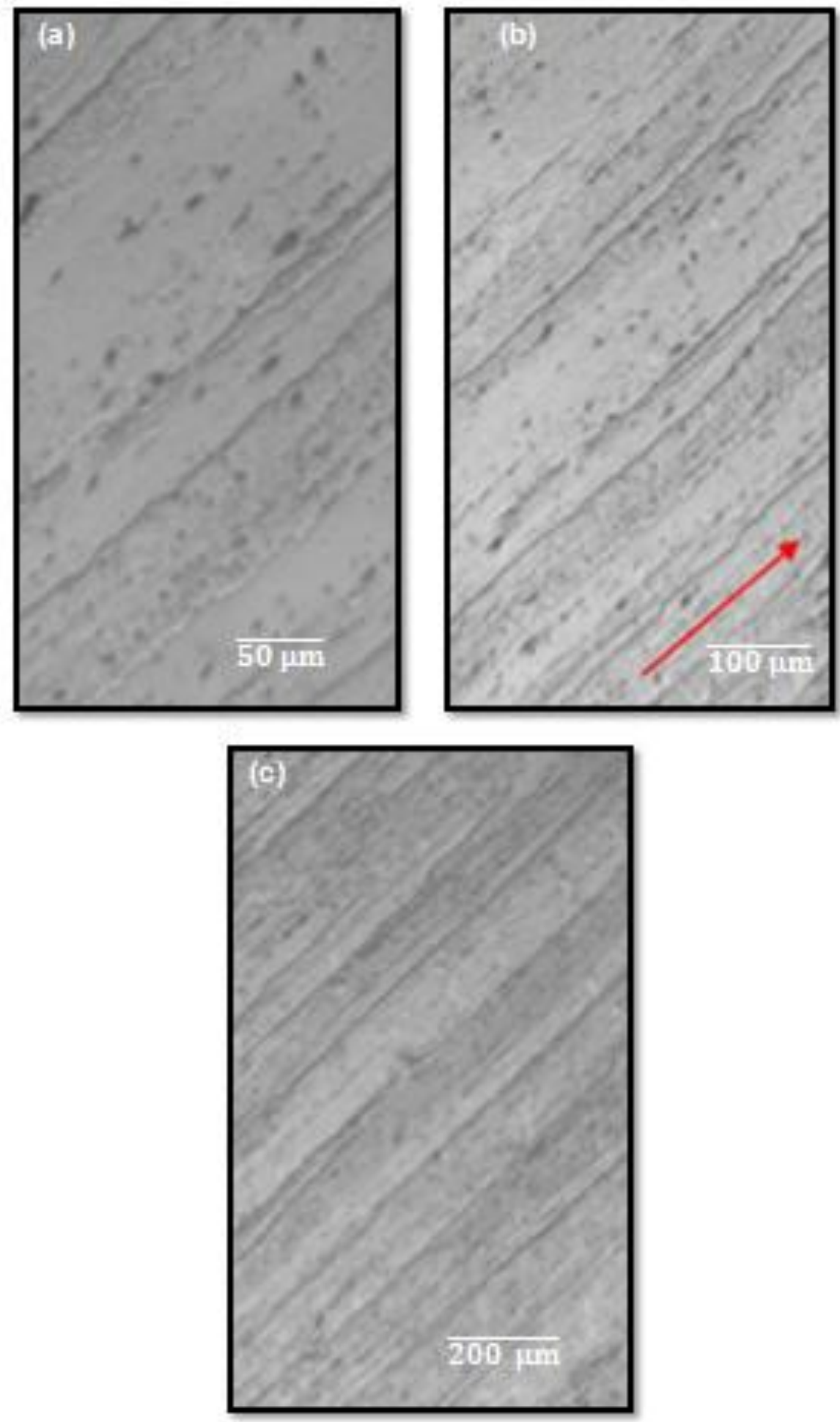

Figura 28. Micrografias da secção transversal da liga AA 1050 - material como recebido: (a) aumento 50X; (b) aumento 100X, com o sentido da extrusão; (c) aumento 200X. 


\subsubsection{Microscopia Eletrônica de Varredura (MEV) - Espectro} de Dispersão de energia (EDS)

Tomando ainda o material como recebido, ele foi submetido à microscopia eletrônica de varredura, MEV, e o acessório de espectroscopia por energia dispersiva, EDS, forneceu o espectro de dispersão de energia dos elementos químicos que compõem a liga AA 1050 como apresentado na Figura 29. A análise do espectro obtido informou então tratar-se de um material composto praticamente de alumínio puro, com um percentual muito baixo de oxigênio.

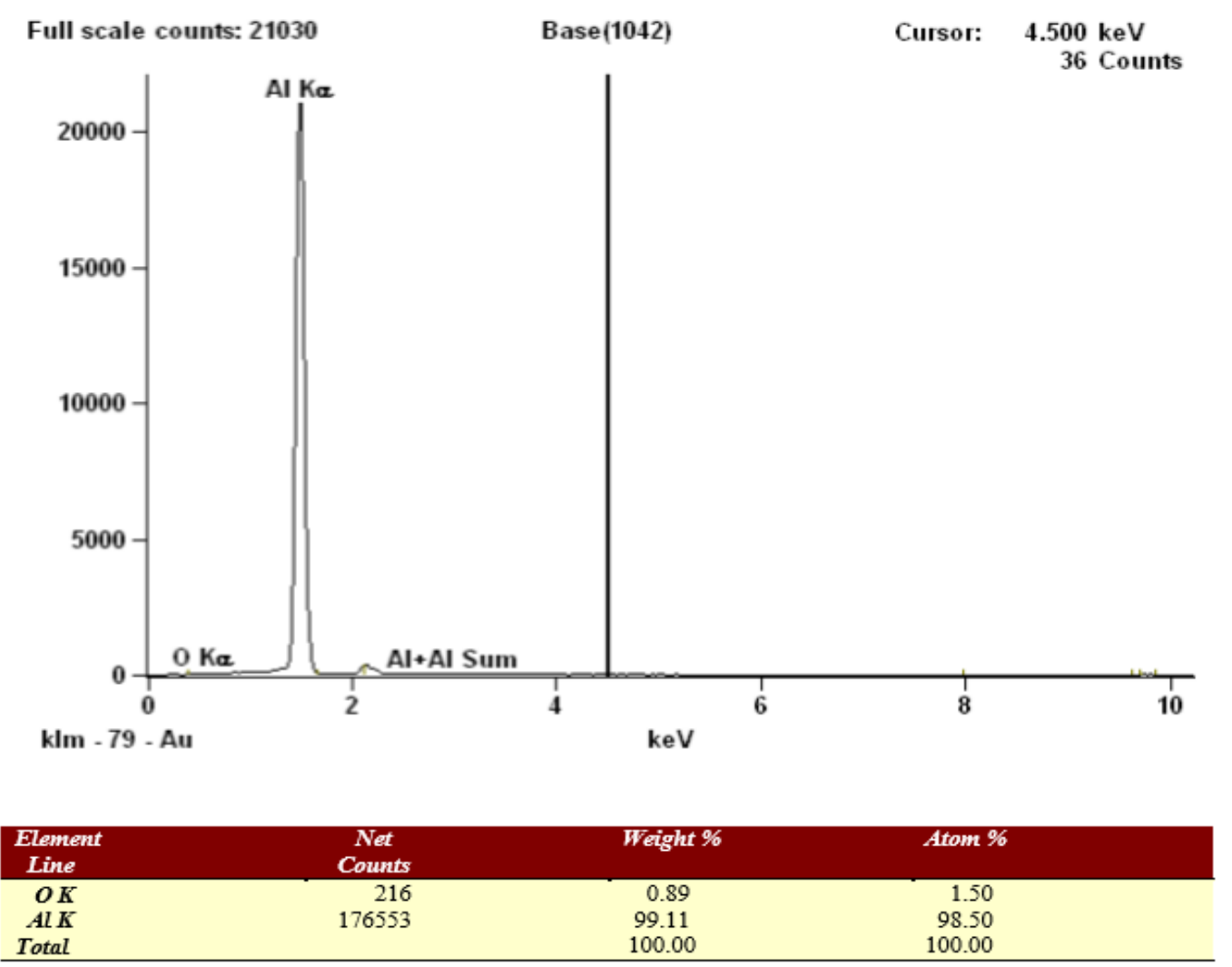

Figura 29. Espectro de dispersão de energia (EDS) para a liga de alumínio $A A$ 1050 - Material como recebido. 
5.2.2. Caracterização Microestrutural, Mecânica e Elétrica do Material da liga AA 1050 pós Tratamento Térmico Inicial (400ㄷ - 30 min), pré Prensagem por Canais Equiangulares - PCE

O material da liga AA 1050, como recebido, logo após a sua caracterização microestrutural, foi levado ao tratamento térmico inicial, um recozimento, de $400 \stackrel{\circ}{\mathrm{C}}$ por 30 minutos e resfriado em água com gelo fundente, com a finalidade de aliviar as tensões residuais da produção das placas por laminação a quente. Após esse tratamento térmico o material foi novamente submetido às caracterizações microestrutural, com microscopia óptica (MO) e eletrônica de transmissão (MET), antes, porém, da submissão ao processo de prensagem por canais equiangulares - PCE.

\subsubsection{Microscopia Óptica (MO)}

A microscopia óptica foi realizada com três aumentos diferentes: (a) 50X; (b) 100X e c) 200X e sob os pontos de vista das secções normal, conforme Figura 30; longitudinal, segundo Figura 31 e transversal, mostrada pela Figura 32.

A análise das micrografias (50X, 100X, 200X) das secções normal, longitudinal e transversal da liga AA 1050 apresentadas revelaram grãos sem excesso de crescimento, com formato equiaxial, sem os alongamentos vistos antes do tratamento térmico (Figuras 27 e 28). O formato evidenciado tornou -se mais afeito aos mecanismos de prensagem por canais equiangulares, (PCE), segundo registrado na literatura. (GUERRA, 2015). 

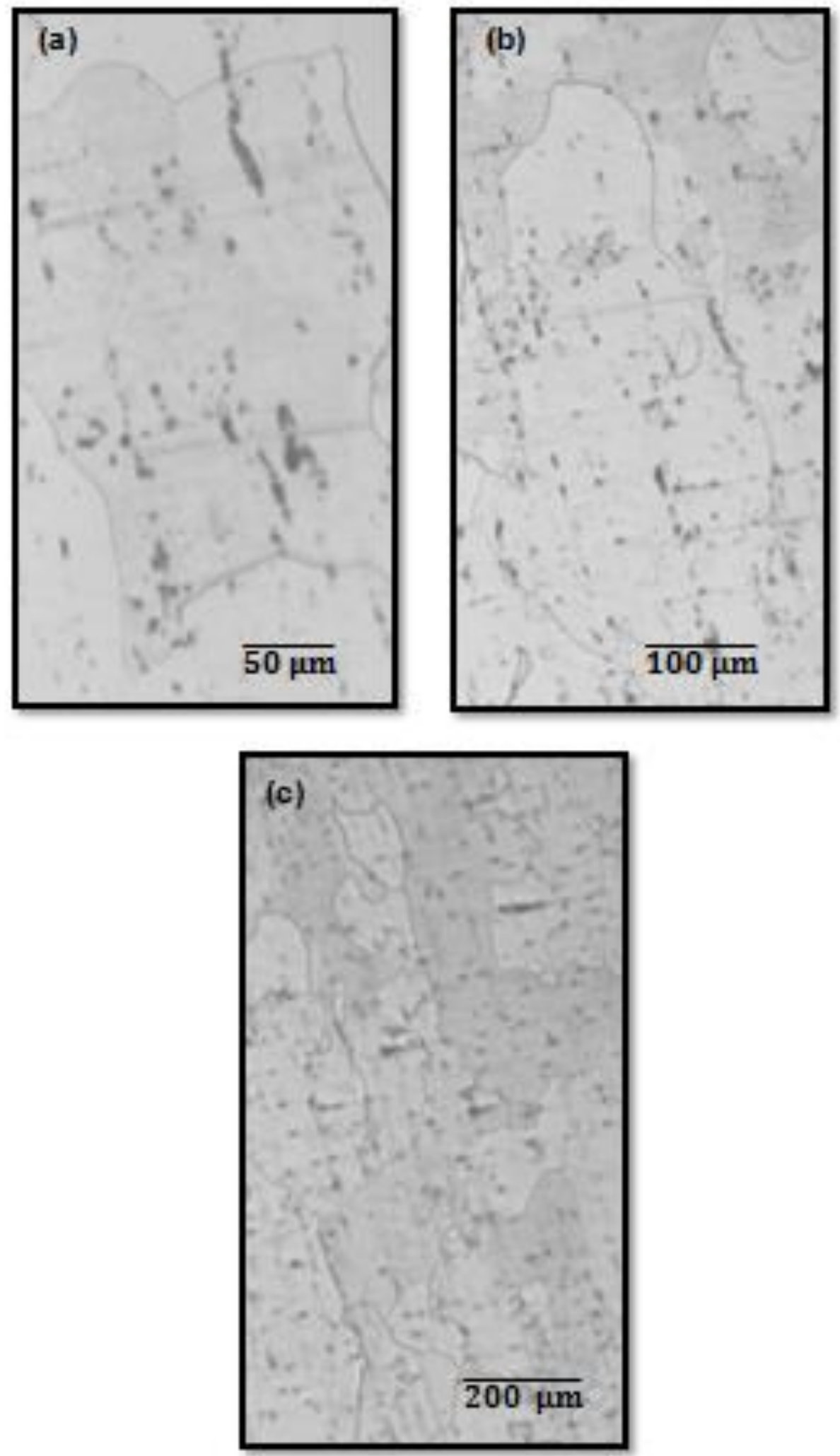

Figura 30. Micrografias da secção normal da liga AA 1050 - pós tratamento térmico inicial, pré PCE: (a) aumento 50X; (b) aumento 100X; (c) aumento 200X. 

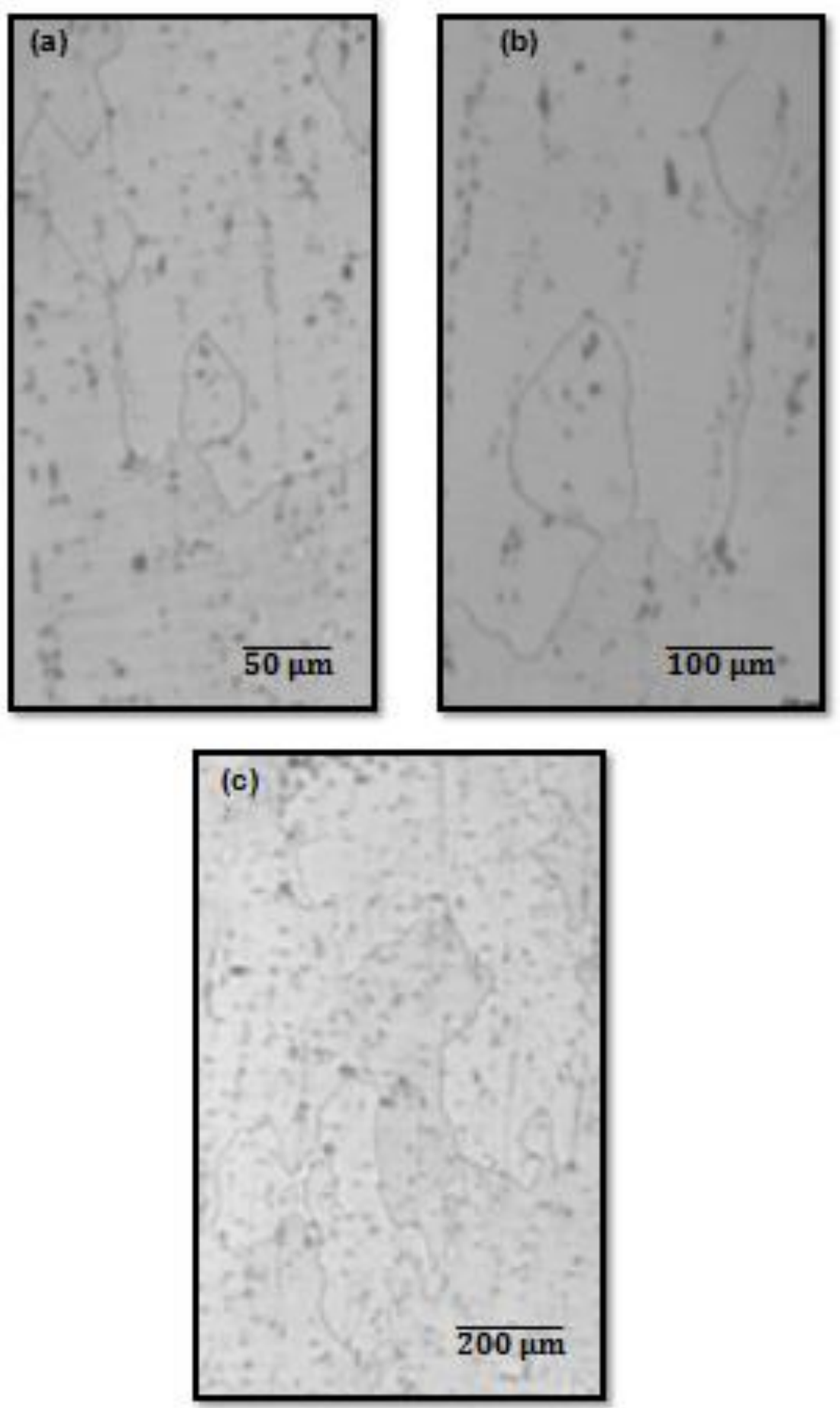

Figura 31. Micrografias da secção longitudinal da liga AA 1050 - pós tratamento térmico inicial, pré PCE: (a) aumento 100X; (b) aumento 200X; (c) aumento 300X. 

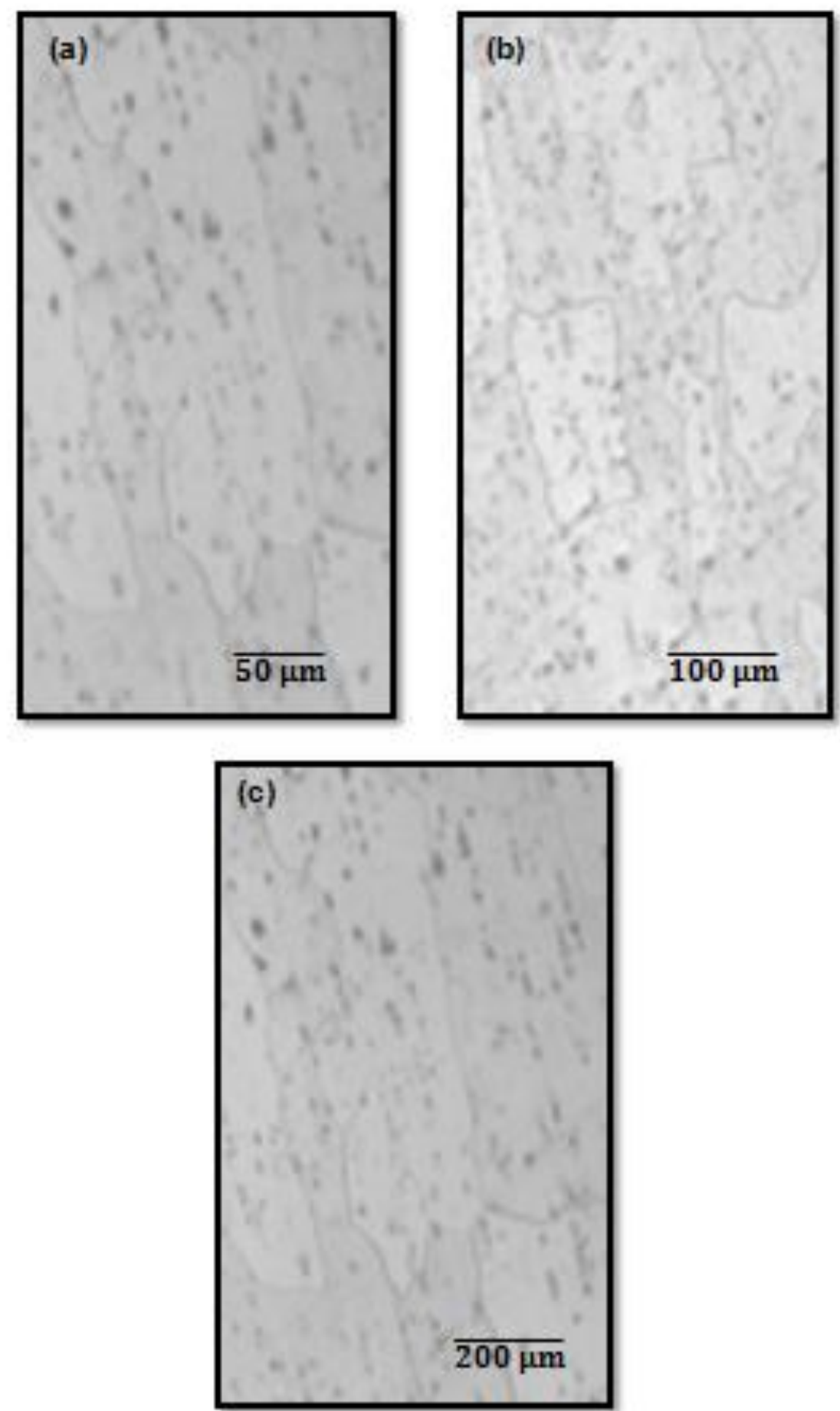

Figura 32. Micrografias da secção transversal da liga AA 1050 - pós tratamento térmico inicial, pré PCE: (a) aumento 50X; (b) aumento 100X; (c) aumento 200X. 


\subsubsection{Microscopia Eletrônica de Transmissão (MET)}

Análises microestruturais que não foram efetuadas pela microscopia óptica puderam ser realizadas pela microscopia eletrônica de transmissão, MET, tais como tamanho de grão e sua nucleação, subgrãos, precipitados e discordâncias, conforme micrografias mostradas na Figura 33. Assim, a análise eletrônica pelo MET possibilitou a observação de detalhes não percebidos pela microscopia óptica, dado o muito reduzido tamanho de grão.

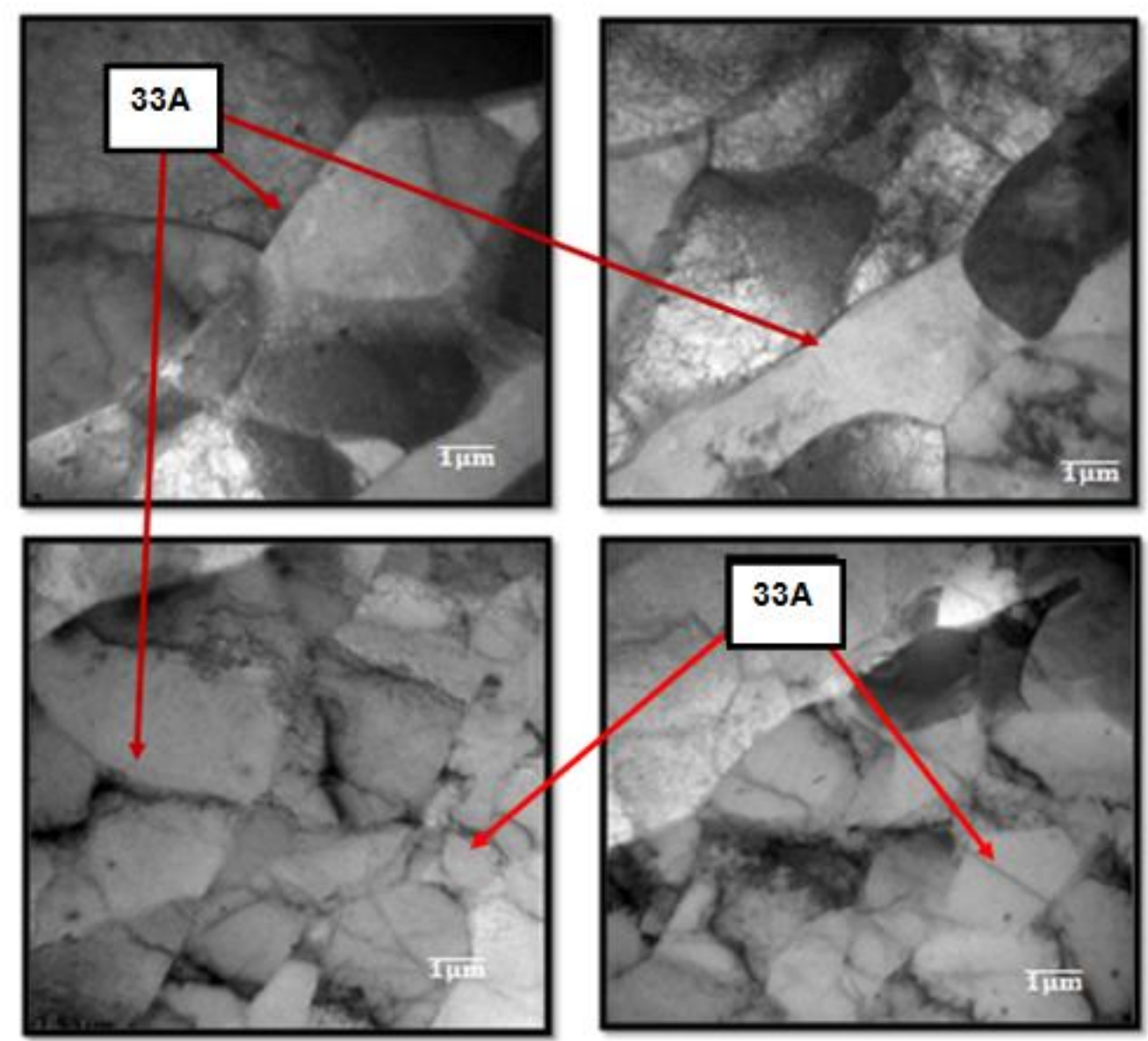

Figura 33. MET - Micrografias eletrônicas de transmissão da secção transversal da liga AA 1050 - pós tratamento térmico inicial, pré PCE: após tratamento inicial (400 ํ - $30 \mathrm{~min})$ - pré PCE. (33A). Contornos de grãos. (33B) Subgrãos e nucleação. 
A análise das micrografias eletrônicas do MET confirmaram as informações das micrografias ópticas e revelaram grãos com contornos bem definidos, sem as deformações de alongamentos vistos antes do tratamento térmico inicial ( $400^{\circ} \mathrm{C}-30$ minutos). Essas micrografias mostram ainda que, após o recozimento, os grãos se apresentaram com formato equiaxiais, mais adequados para os processos de prensagem por canais equiangulares, que foram realizados na etapa seguinte do fluxograma de etapas experimentais, expresso na Figura 05.

\subsubsection{Determinação de Microdureza Vickers (HV)}

Com o objetivo de comparar a medida de microdureza do material da liga AA 1050 nas diversas etapas experimentais é efetuada uma medição formada pela série da Tabela 09, da qual se calcula 0 valor médio com a respectiva tolerância. Após a obtenção dos demais valores antes e depois do material submetido aos processos PCE fica em evidência a variação desta propriedade mecânica do material.

Tabela 09 - Microdureza Vickers (HV) - Liga AA 1050 - após tratamento térmico inicial ( $400{ }^{\circ} \mathrm{C}-30$ minutos), pré prensagem por canais equiangulares - PCE. Carga de $300 \mathrm{~g}$.

\begin{tabular}{|c|c|}
\hline MEDIDA & VALOR (HV) \\
\hline$M_{1}$ & 34,9 \\
\hline$M_{2}$ & 33,0 \\
\hline$M_{3}$ & 32,9 \\
\hline$M_{4}$ & 34.4 \\
\hline$M_{5}$ & 35,7 \\
\hline$\overline{\mathbf{M}}$ & $\mathbf{3 4} \pm \mathbf{2}$ \\
\hline
\end{tabular}




\subsubsection{Determinação da Condutividade Elétrica $(\sigma)$}

Esta propriedade elétrica do material foi medida de forma indireta, através de sua resistência elétrica, esta sim, uma grandeza mensurável. 0 embasamento teórico e o método foram apresentados neste trabalho quando da medição da condutividade do material da liga AA 3003. Entretanto, de forma distinta, parte-se agora da segunda lei de Ohm, de onde vem

$$
\rho=\frac{R \cdot A}{\lambda}
$$

Onde $R$ simboliza resistência elétrica entre dois pontos do material distanciados de $\lambda$. A, representa a área da secção transversal e $\rho$ a resistividade. Tomando a condutividade $\sigma$ do material como o inverso da resistividade vem

$$
\sigma=\frac{1}{\rho}
$$

Do sistema internacional de unidades pode escrever

$$
\text { unidade }(\sigma)=\Omega^{-1} \cdot \mathrm{m}^{-1}
$$

Após o tratamento térmico inicial de recozimento os valores das dimensões da amostra da liga AA 1050, sua resistência elétrica $(R)$, sua resistividade elétrica $(\rho)$ e a sua condutividade $(\sigma)$ foram mensuradas e registradas, conforme indica a Tabela 10 . 0 valor médio da resistência elétrica veio de uma série de três medidas. Com a colocação dos valores coletados depois do tratamento térmico final foi possível avaliar a variação das propriedades elétrica do material em estudo.

Tabela 10: Medidas da Resistência, Resistividade e Condutividade elétricas da liga $A A 1050$, pós tratamento térmico inicial (400 ํㅡ -30 minutos), pré prensagem por canais equiangulares.

\begin{tabular}{|c|c|}
\hline GRANDEZA & VALOR \\
\hline Dimensões da Amostra & $6 \times 6 \times 30,90 \mathrm{~mm}$ \\
\hline Resistência Elétrica $(R)$ & $(5,9 \pm 0,3) \cdot 10^{-5} \Omega$ \\
\hline Resistividade Elétrica $(\rho)$ & $6,9.10^{-8} \Omega \cdot \mathrm{m}$ \\
\hline Condutividade Elétrica $(\sigma)$ & $1,4 \cdot 10^{7} \Omega^{-1} \cdot \mathrm{m}^{-1}$ \\
\hline
\end{tabular}




\subsubsection{Caracterização Microestrutural, Mecânica e Elétrica do} Material da liga AA 1050, pós Prensagem por Canais Equiangulares - PCE, pré Tratamentos Térmicos Posteriores

\subsubsection{Microscopia Óptica (MO)}

O objetivo geral desta pesquisa é o mecanismo associado ao refino de grão em ligas de alumínio após técnica de prensagem por canais equiangulares - PCE. Torna-se importante comparar os estudos efetuados sobre as ligas antes do mecanismo e depois dele, incluindo o tratamento térmico posterior ao PCE, isto é, o envelhecimento das amostras e as rotas adotadas para a prensagem, rota $\mathrm{A}$ ou rota $\mathrm{Bc}$.

\subsection{Micrografias das Amostras Prensadas pela rota A}

Todos os tarugos da liga AA 1050 prensados possuem quatro passes, isto é, realizaram quatro vezes a rota $A$, sem rotação da amostra, sempre em um mesmo sentido. Logo são excluídas as deformações redundantes, quando há retorno microestrutural à configuração de início, após cada passe de número par, como ocorre na rota $\mathrm{Bc}$, que foi analisada nas micrografias do próximo tópico. As micrografias apresentadas indicam, além do sentido de extrusão do material, os planos microscópicos de visão normal segundo a Figura 34; longitudinal, conforme a Figura 35, e transversal, mostrados pela Figura 36. Para cada um dos planos há três diferentes aumentos: (a) 50X; (b) 100X e (c) $200 X$.

A análise das micrografias mostradas pelas Figuras 34 a 36 , que englobou os planos microscópicos de visão normal, longitudinal e transversal, em todos os aumentos estipulados, indicou grãos muito alongados na direção da extrusão, que deformaram por inteiro a microestrutura, evidenciando as linhas de deformação ou planos de escorregamento, devido ao cisalhamento intenso efetuado. Entretanto não foi possível concluir a ocorrência de recristalização por microscopia óptica, possivelmente por motivo do tamanho de grão diminuto. 

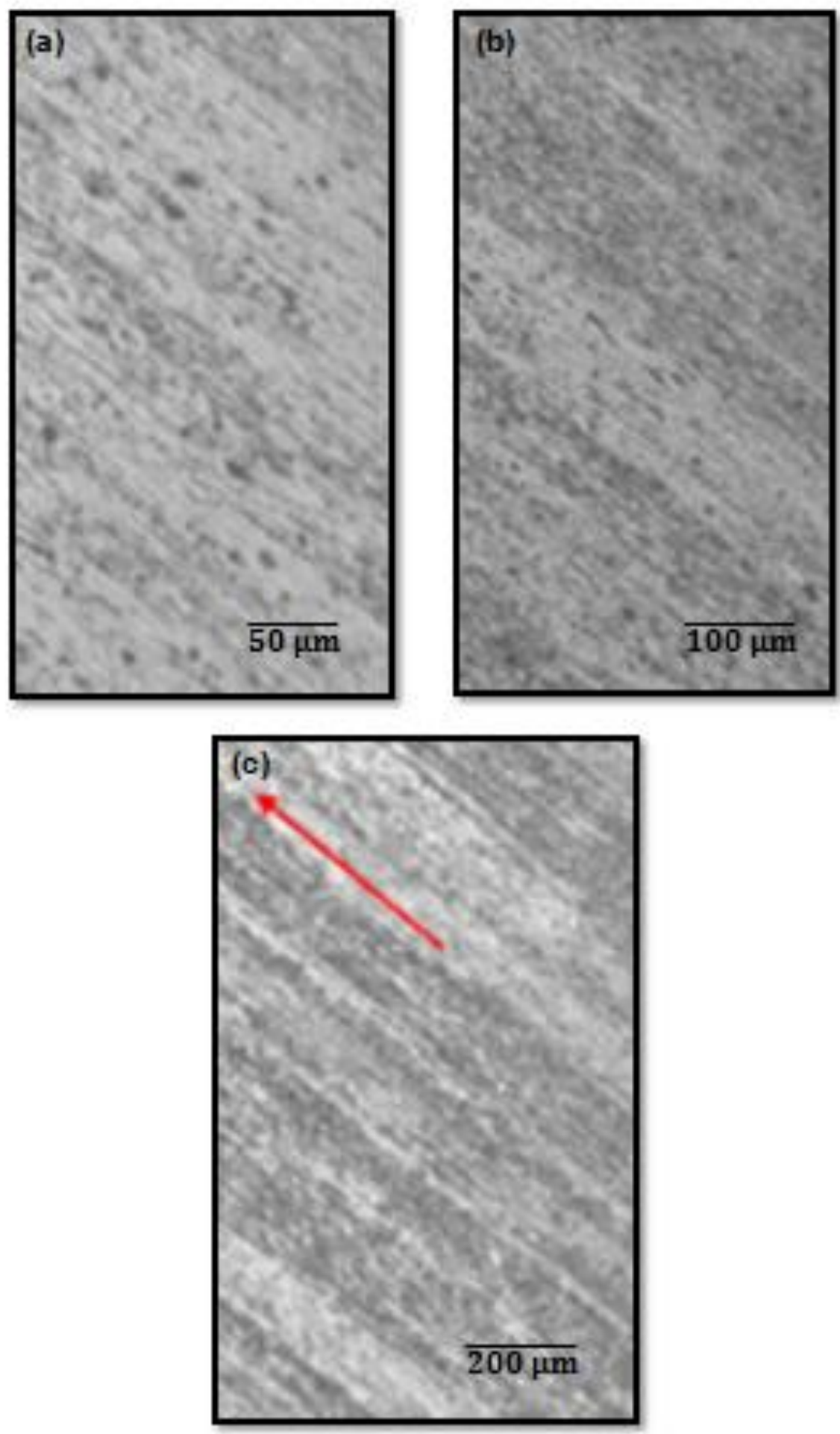

Figura 34. Micrografias da secção normal da liga AA 1050 - pós prensagem por canais equiangulares - PCE (4 passes - rota A): (a) aumento 50X; (b) aumento 100X; (c) aumento 200X, com a indicação do sentido de extrusão. 

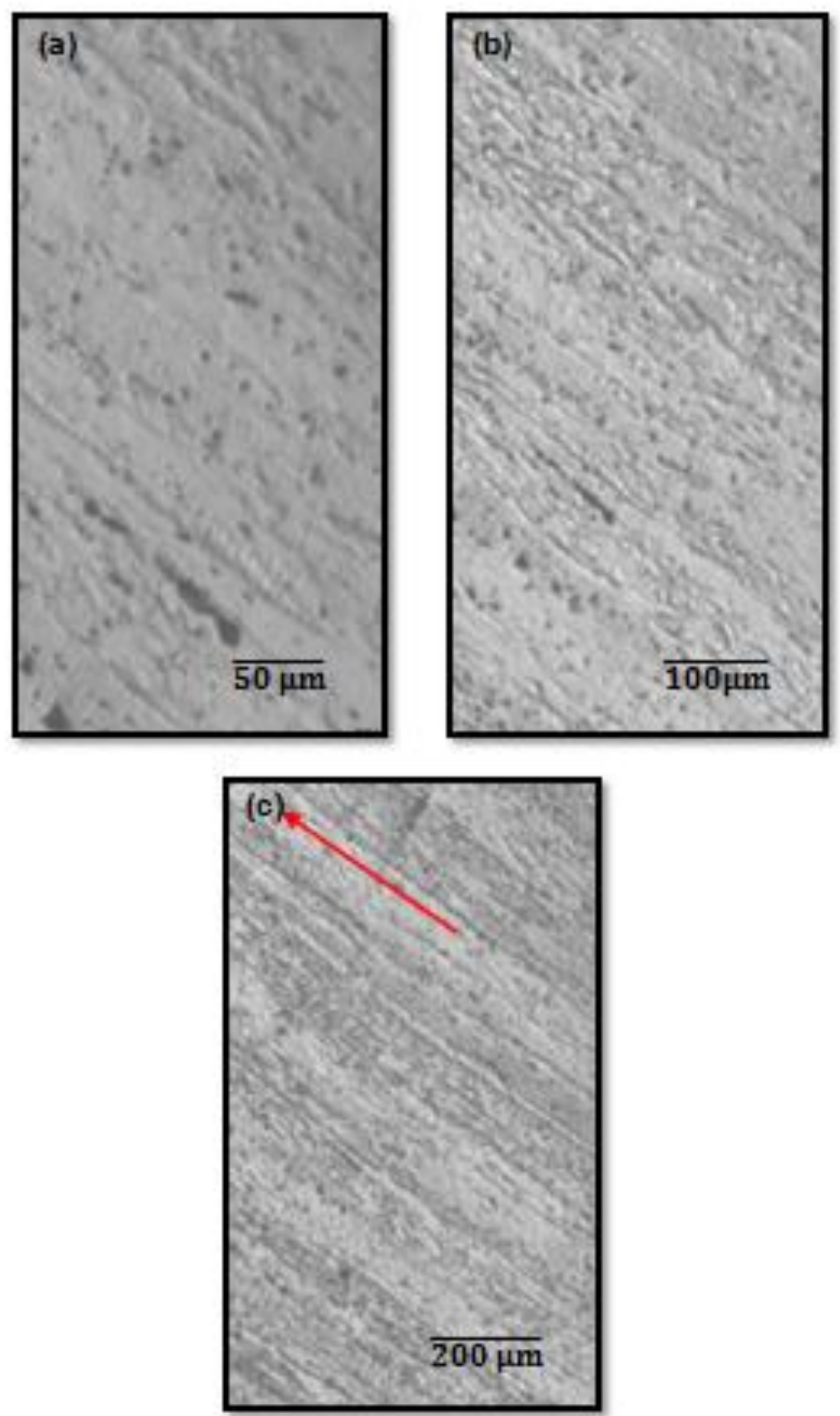

Figura 35. Micrografias da secção longitudinal da liga AA 1050 - pós prensagem por canais eqangulares - PCE (4 passes - rota A): (a) aumento 50X; (b) aumento 100X; (c) aumento 200X, com a indicação do sentido de extrusão. 

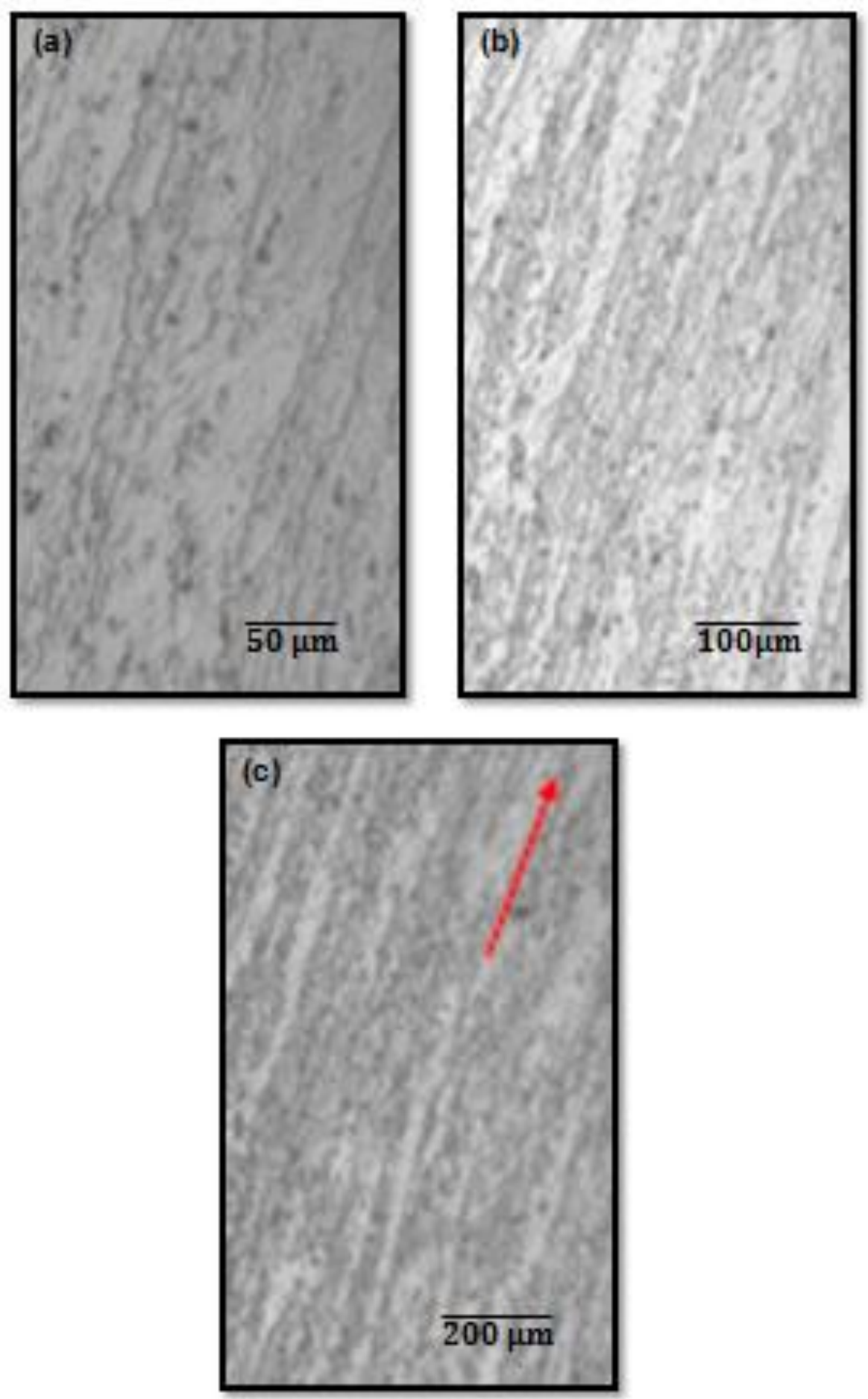

Figura 36. Micrografias da secção transversal da liga AA 1050 - pós prensagem por canais equiangulares - PCE (4 passes - rota A): (a) aumento 50X; (b) aumento 100X; (c) aumento 200X, com a indicação do sentido de extrusão. 


\subsection{Micrografias das Amostras Prensadas pela rota Bc}

Conforme resumo de distribuição de amostras da liga AA 1050 para o processo de prensagem por canais equiangulares - PCE, mostrado na Figura 12, dez tarugos foram submetidos ao PCE pela rota $\mathrm{Bc}$, todos submetidos a quatro passes. As micrografias foram analisadas sob os planos microscópicos de visão longitudinal e transversal, com os aumentos: (a) 50X e (b) 100X, conforme indicado nas Figuras 38 e 39.
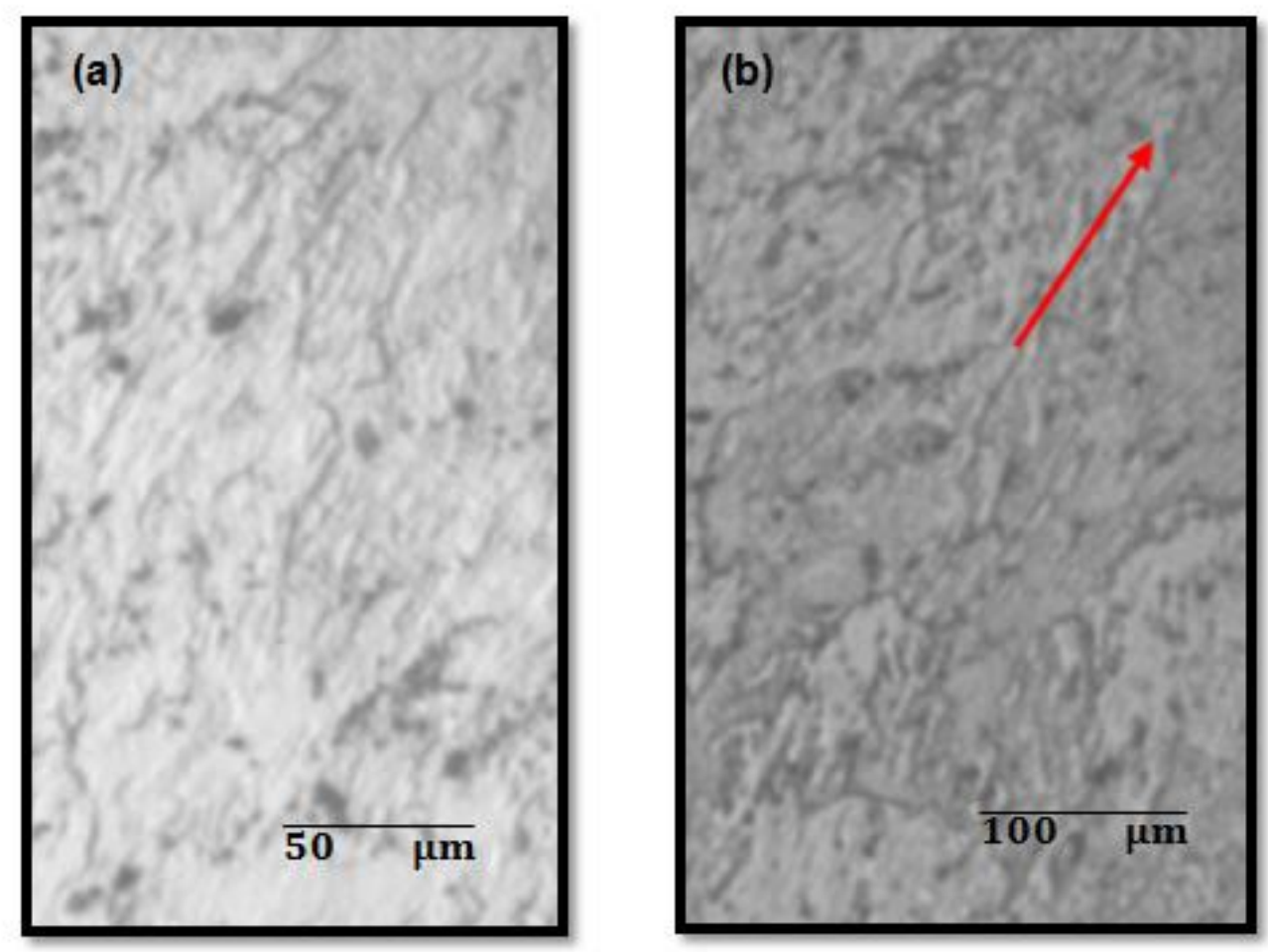

Figura 37. Micrografias da secção longitudinal da liga AA 1050 - pós prensagem por canais equiangulares - PCE (4 passes - rota Bc): (a) aumento 50X; (b) aumento 100X, com a indicação do sentido de extrusão. 

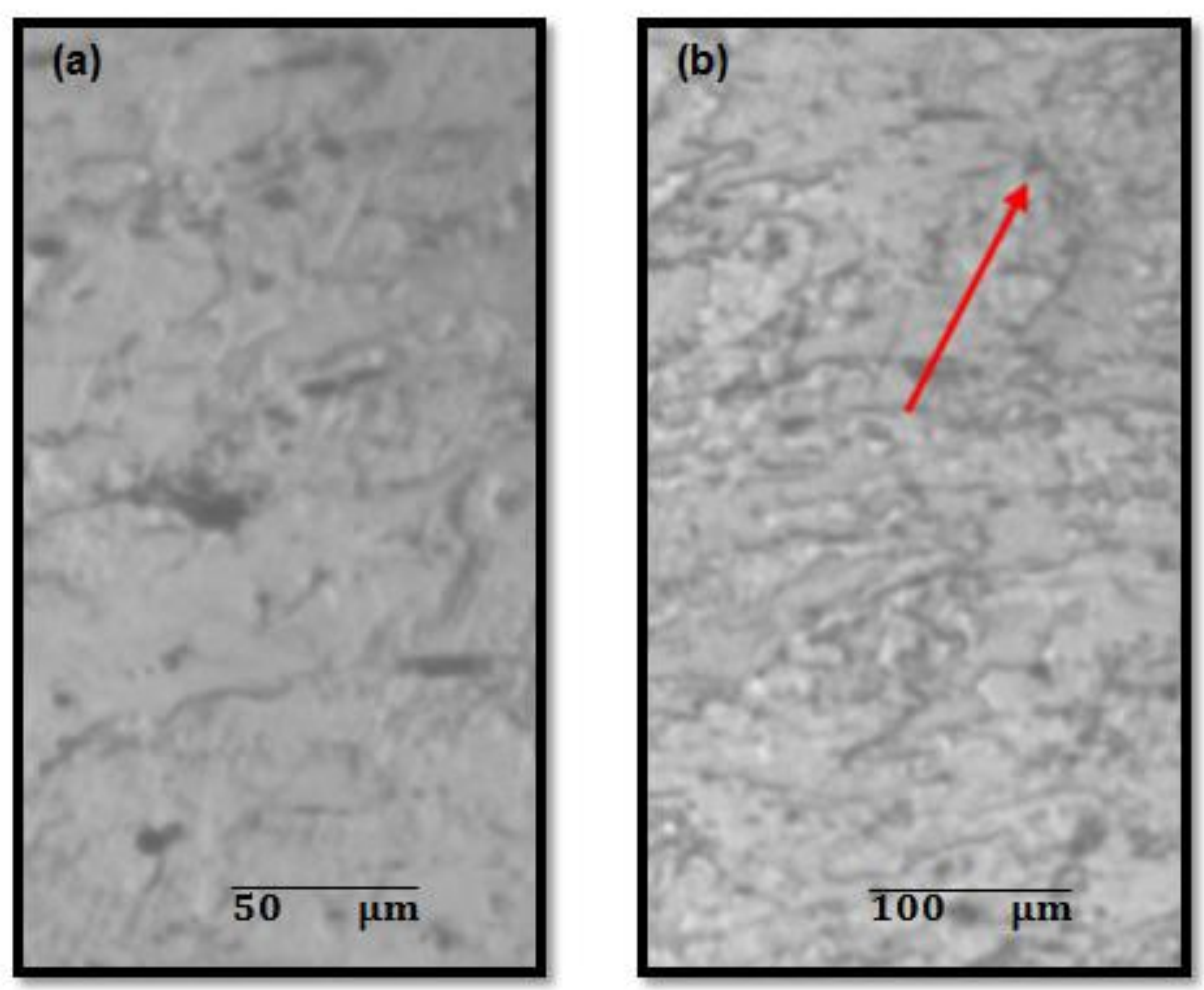

Figura 38. Micrografias da secção transversal da liga AA 1050 - pós prensagem por canais equiangulares - PCE (4 passes - rota Bc): (a) aumento 50X; (b) aumento 100X, com a indicação do sentido de extrusão.

Segundo apresenta a revisão da literatura realizada para esta pesquisa, o tamanho de grão e a homogeneidade de deformação estão diretamente associados às distintas modalidades de extrusão. As micrografias das amostras prensadas pela rota Bc não apresentaram os grãos tão alongados quanto os da rota $A$ e nem a nitidez das linhas de deformação, porém, ficou nítida a diminuição do tamanho de grão devido ao cisalhamento imposto ao material. Comparando-se as micrografias do material da liga AA 1050 após o tratamento térmico inicial, antes da sua submissão ao processo de prensagem por canais equiangulares - PCE, Figuras 29 a 31 e depois do processo PCE, Figuras 37 e 38, a mudança microestrutural foi significativa. Os grãos, nestas últimas figuras não apresentaram a equiaxialidade dos tratados termicamente, das primeiras figuras, porém, o tamanho de grão foi perceptivelmente menor. 


\subsubsection{Determinação de Microdureza Vickers (HV) após PCE}

Na Tabela 11 foram colocados os valores médios com a respectiva tolerância, das medições efetuadas nas amostras que foram submetidas ao processo PCE tanto pela rota A quanto pela rota Bc. A tabela também apresenta os valores de microdureza das mesmas amostras antes de serem submetidas ao processo PCE, para que fosse realizada a análise da variação desta propriedade mecânica do material que compõe a liga AA 1050.

Tabela 11 - Microdureza Vickers (HV) - Liga AA 1050 - pré PCE - prensagem por canais equiangulares e pós PCE, (rota A e rota Bc). Carga de $300 \mathrm{~g}$.

\begin{tabular}{|c|c|c|c|}
\cline { 2 - 4 } \multicolumn{1}{c|}{} & \multicolumn{3}{c|}{ MICRODUREZA VICKERS (HV) } \\
\hline MEDIDA & PRE PCE & PCE ROTA A & PCE ROTA Bc \\
\hline$M_{1}$ & 34,9 & 42,5 & 47,1 \\
\hline$M_{2}$ & 33,0 & 43,7 & 46,8 \\
\hline$M_{3}$ & 32,9 & 43,8 & 47,6 \\
\hline$M_{4}$ & 34,4 & 42,4 & 46,6 \\
\hline$M_{5}$ & 35,7 & 43,1 & 46,5 \\
\hline$\overline{\mathbf{M}}$ & $\mathbf{3 4} \mathbf{2}$ & $\mathbf{4 3} \pm \mathbf{1}$ & $\mathbf{4 7} \pm \mathbf{1}$ \\
\hline
\end{tabular}

Observou-se pela análise dos valores registrados na Tabela 07, que houve melhoria na propriedade mecânica de dureza do material da liga AA 1050, resultado da eficiência do processo de prensagem por canais equiangulares PCE que provocou a deformação plástica intensa DPI no material. O aumento da microdureza do material como recebido atingiu o percentual médio de $26 \%$ quando comparado ao material que percorreu a rota $A$ e quando comparado ao material prensado pela rota $\mathrm{Bc}$ o percentual de aumento da microdureza foi de $38 \%$. Percebeu-se então, que a rota de maior eficiência para este material é a Bc, 
que impôs ao material maior acúmulo de deformação o que pode ter provocado maior refino dos grãos.

\subsubsection{Determinação da Resistência, Resistividade e} Condutividade Elétrica $(\sigma)$ do Material das Amostras Submetidas à PCE liga AA 1050.

Na Tabela 12 são apresentados os valores médios, acompanhados da respectiva tolerância, de resistência, resistividade e condutividade elétricas do material das amostras submetidas ao mecanismo de prensagem por canais equiangulares - PCE. Acompanham os valores obtidos antes da PCE para que seja analisada a variação da propriedade elétrica condutividade do material $(\sigma)$ antes e depois da submissão do material aos processos da PCE.

Tabela 12. Medidas da Resistência, Resistividade e Condutividade elétricas da liga AA 1050, antes da PCE e pós PCE (Rotas A e Bc)

\begin{tabular}{|l|c|c|l|}
\hline \multicolumn{1}{|c|}{ GRANDEZA } & PRE PCE & PCE ROTA A & PCE ROTA Bc \\
\hline Dimensões da Amostra & $6 \times 6 \times 30,90 \mathrm{~mm}$ & $6 \times 6 \times 23,63 \mathrm{~mm}$ & $6 \times 6 \times 17,95 \mathrm{~mm}$ \\
\hline Resistência Elétrica $(\mathrm{R})$ & $(5,9 \pm 0,3) \cdot 10^{-5} \Omega$ & $(7,0 \pm 0,2) \cdot 10^{-5} \Omega$ & $(6,6 \pm 0,4) \cdot 10^{-5} \Omega$ \\
\hline Resistividade Elétrica $(\rho)$ & $6,9 \cdot 10^{-8} \Omega \cdot \mathrm{m}$ & $1,1 \cdot 10^{-7} \Omega \cdot \mathrm{m}$ & $1,3 \cdot 10^{-7} \Omega \cdot \mathrm{m}$ \\
\hline Condutividade Elétrica $(\sigma)$ & $1,4 \cdot 10^{7} \Omega^{-1} \cdot \mathrm{m}^{-1}$ & $9,4 \cdot 10^{6} \Omega^{-1} \cdot \mathrm{m}^{-1}$ & $7,5 \cdot 10^{6} \Omega^{-1} \cdot \mathrm{m}^{-1}$ \\
\hline
\end{tabular}

A análise da tabela revelou que devido ao encruamento intensivo do material pela DPI, a sua condutividade sofreu uma variação negativa e não houve variações merecedoras de apontamento nas propriedades elétricas em relação às duas rotas adotadas. 
5.2.4. Caracterização Microestrutural, Mecânica e Elétrica do Material da liga AA 1050, pós Prensagem por Canais Equiangulares - PCE, pós Tratamentos Térmicos Posteriores

\subsubsection{Microscopia Óptica (MO)}

Após as análises realizadas para a caracterização do material da liga AA 1050 após prensagem por canais equiangulares, conforme o fluxograma da Figura 06, oito corpos de prova, todos com 4 passagens pelos canais, foram levados a tratamentos térmicos posteriores - envelhecimento -, a $250 \stackrel{\circ}{\circ}$, em intervalos de 30, 60, 90 e 120 minutos. Quatro corpos de prova foram submetidos ao envelhecimento após terem percorrido a rota $A$, enquanto os demais percorreram a rota $\mathrm{Bc}$. Desta forma, foram gerados dois lotes, conforme a rota percorrida. Ato contínuo à submissão do envelhecimento o material de cada um dos lotes foi caracterizado microestrutural, mecânica e eletricamente. As micrografias foram analisadas sob os planos microscópicos de visão normal, longitudinal e transversal, com os aumentos 50X, 100X e 200X, conforme indicado nas Figuras 39 a 55. 
5.2.4.1.1 Micrografias das Amostras Prensadas pela rota A
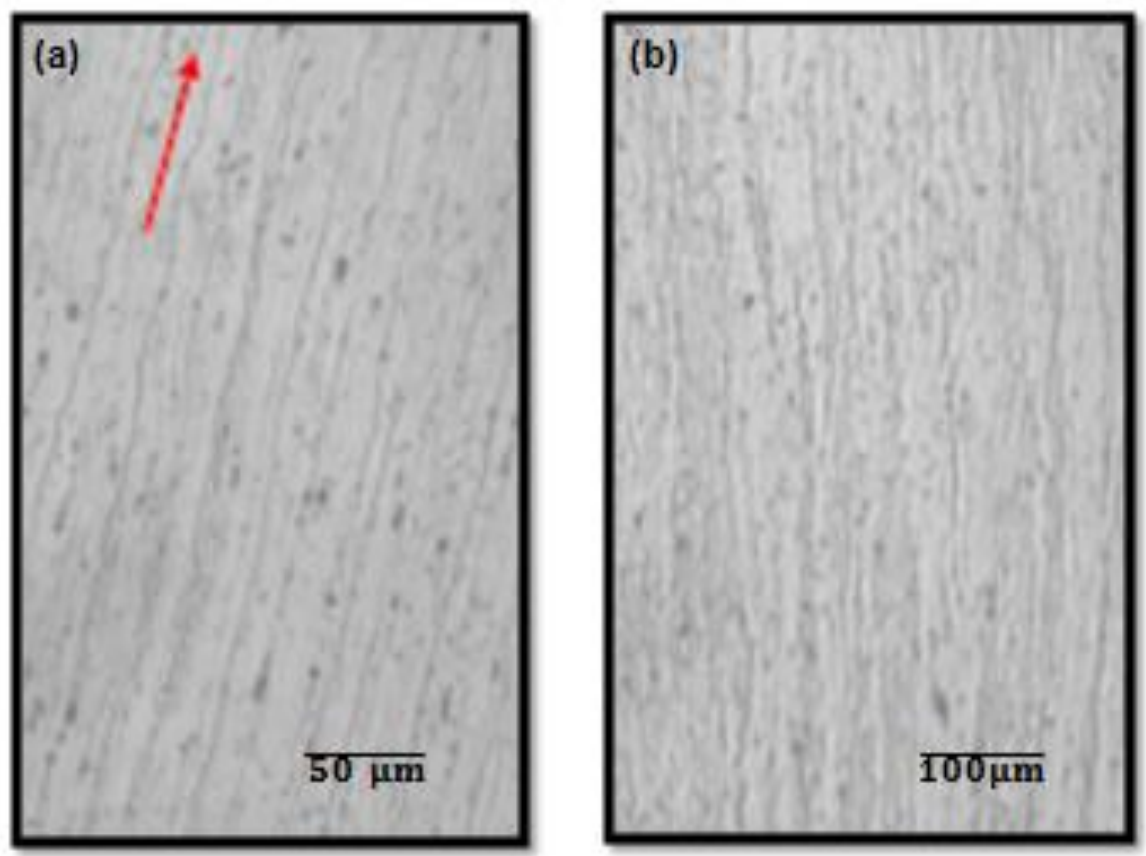

(c)

Figura 39. Micrografias da secção normal da liga AA 1050 - pós PCE - rota A pós envelhecimento ( $250 \stackrel{\circ}{\mathrm{C}}-30$ minutos): (a) aumento $50 \mathrm{X}$, com a indicação do sentido de extrusão; (b) aumento 100X; (c) aumento 200X. 


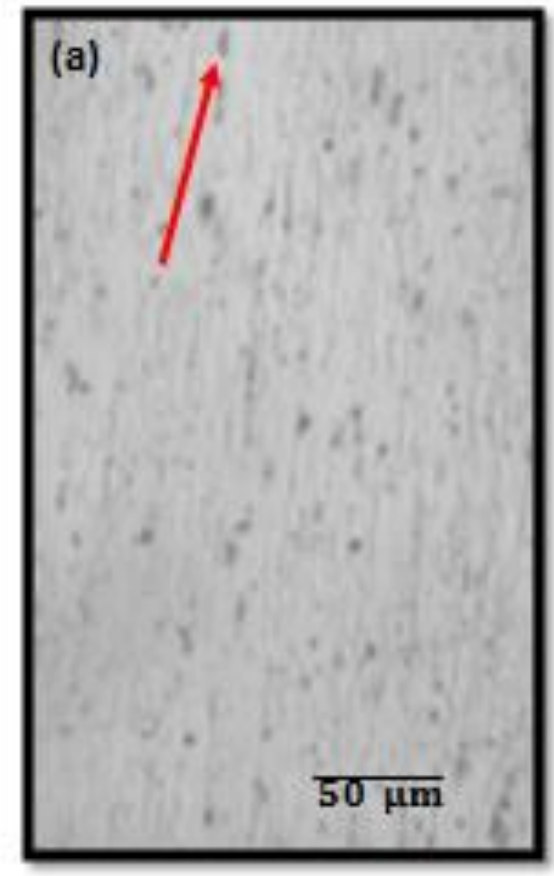

(b)

(c)

$200 \mu \mathrm{m}$

Figura 40. Micrografias da secção transversal da liga AA 1050 - pós - PCE rota $A$ - pós envelhecimento (250 ํㅡ - 30 minutos): (a) aumento 50X, com a indicação do sentido de extrusão; (b) aumento 100X; (c) aumento 200X. 

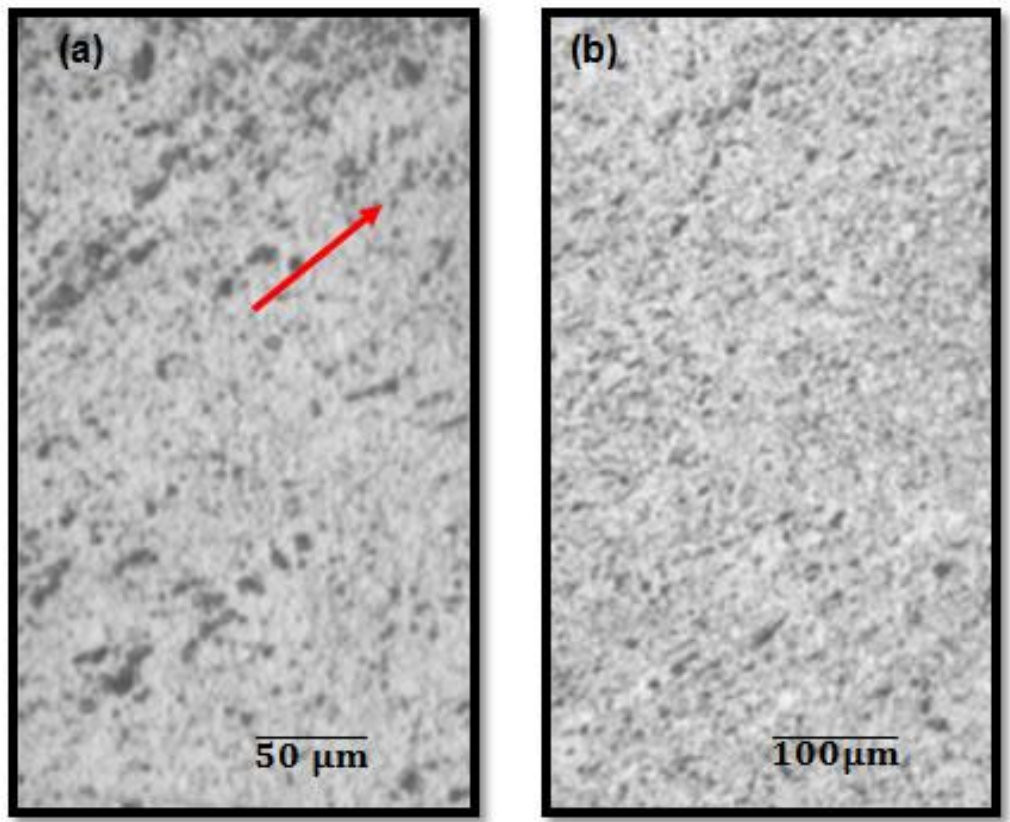

Figura 41. Micrografias da secção normal da liga AA 1050 - pós PCE - rota A pós envelhecimento ( $250^{\circ} \mathrm{C}-60$ minutos): (a) aumento $50 \mathrm{X}$, com a indicação do sentido de extrusão; (b) aumento 100X.
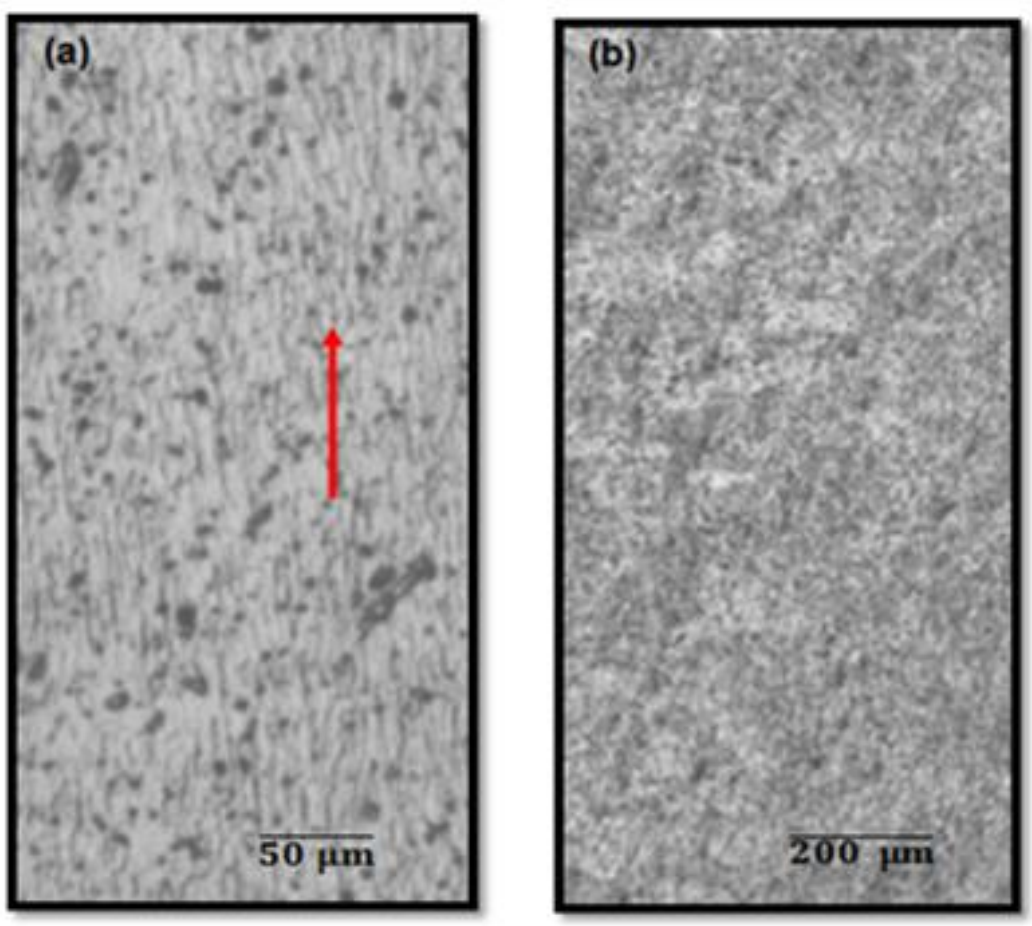

Figura 42. Micrografias da secção transversal da liga AA 1050 - pós PCE - rota A - pós envelhecimento (250 ํㅡ - 60 minutos): (a) aumento $50 \mathrm{X}$, com a indicação do sentido de extrusão; (b) aumento 200X. 

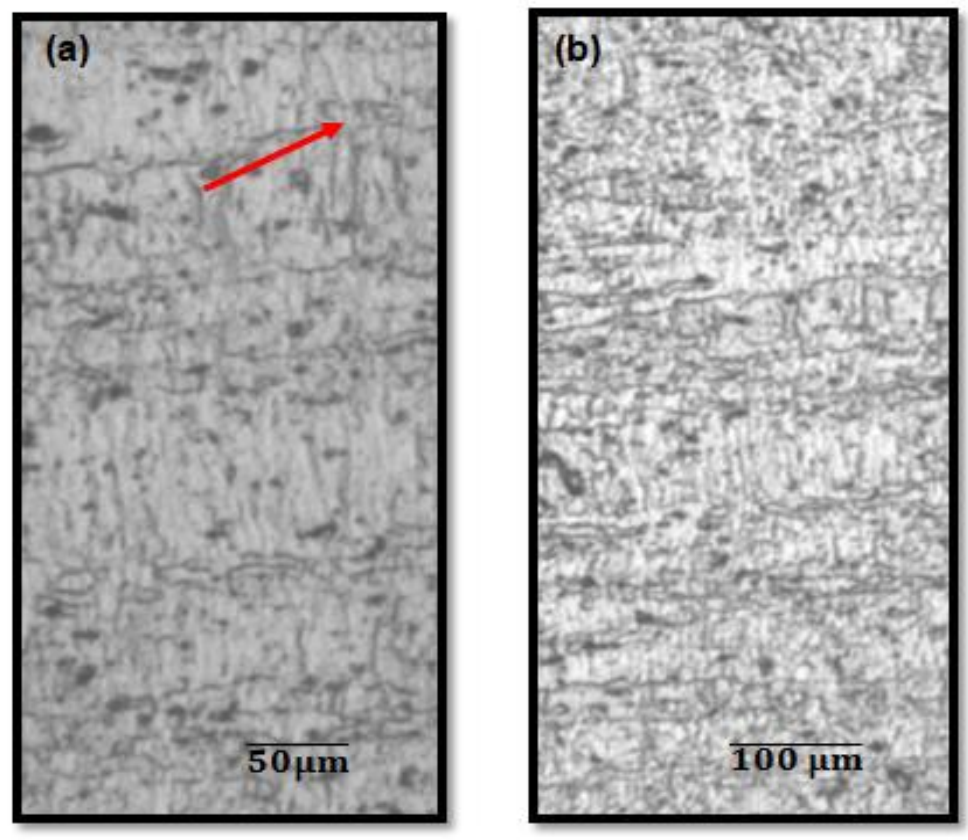

Figura 43. Micrografias da secção longitudinal da liga AA 1050 - pós PCE - rota A - pós envelhecimento (250 ํㅡ - 90 minutos): (a) aumento 50X, com a indicação do sentido de extrusão; (b) aumento 100X.
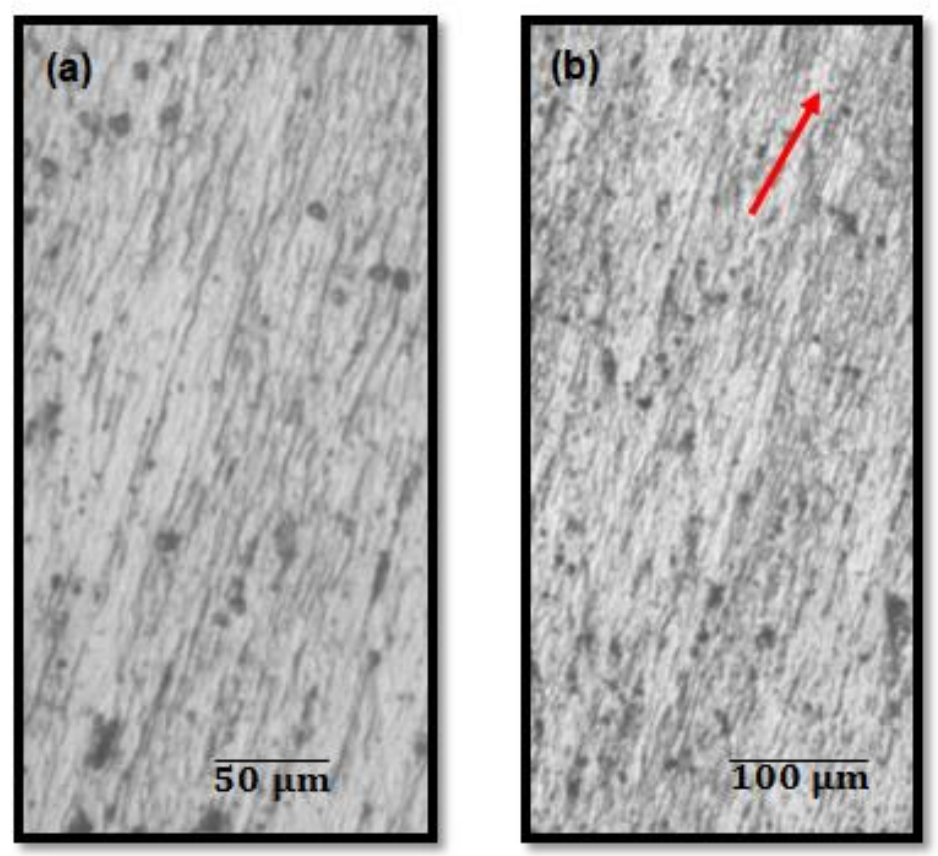

Figura 44. Micrografias da secção transversal da liga AA 1050 - pós PCE - rota A - pós envelhecimento (250 ${ }^{\circ} \mathrm{C}$ - 90 minutos): (a) aumento 50X; (b) aumento 100X, com a indicação do sentido de extrusão. 

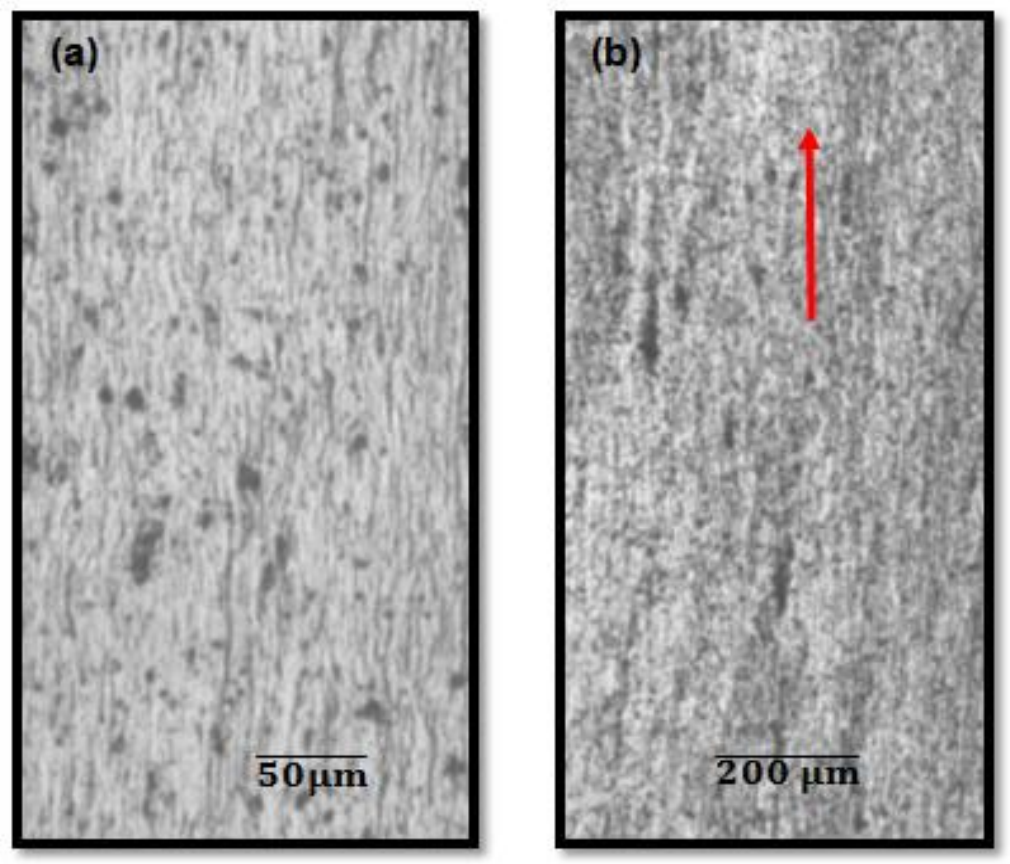

Figura 45. Micrografias da secção normal da liga AA 1050 - pós PCE - rota A pós envelhecimento (250 ํㅡ - 120 minutos): (a) aumento 50X; (b) aumento 200X, com a indicação do sentido de extrusão.
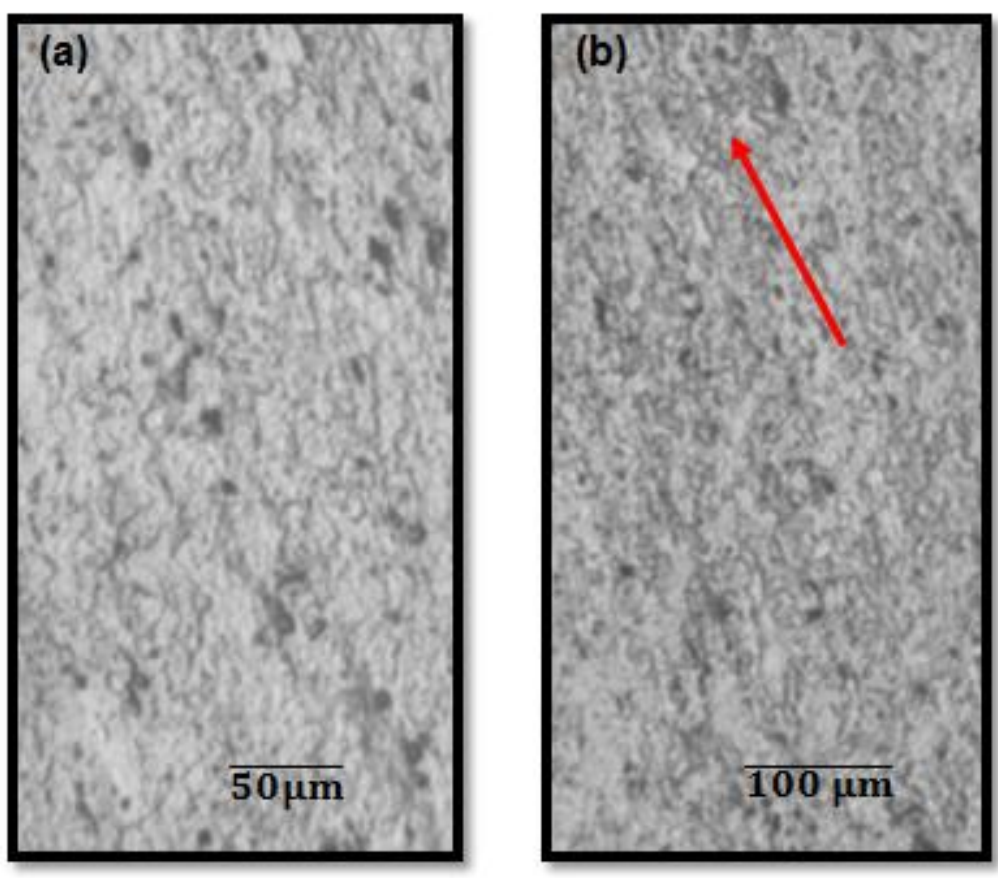

Figura 46. Micrografias da secção longitudinal da liga AA 1050 - pós PCE - rota A - pós envelhecimento (250 ำ - 120 minutos): (a) aumento 50X; (b) aumento 100X, com a indicação do sentido de extrusão. 


\subsection{Micrografias das Amostras Prensadas pela rota Bc}
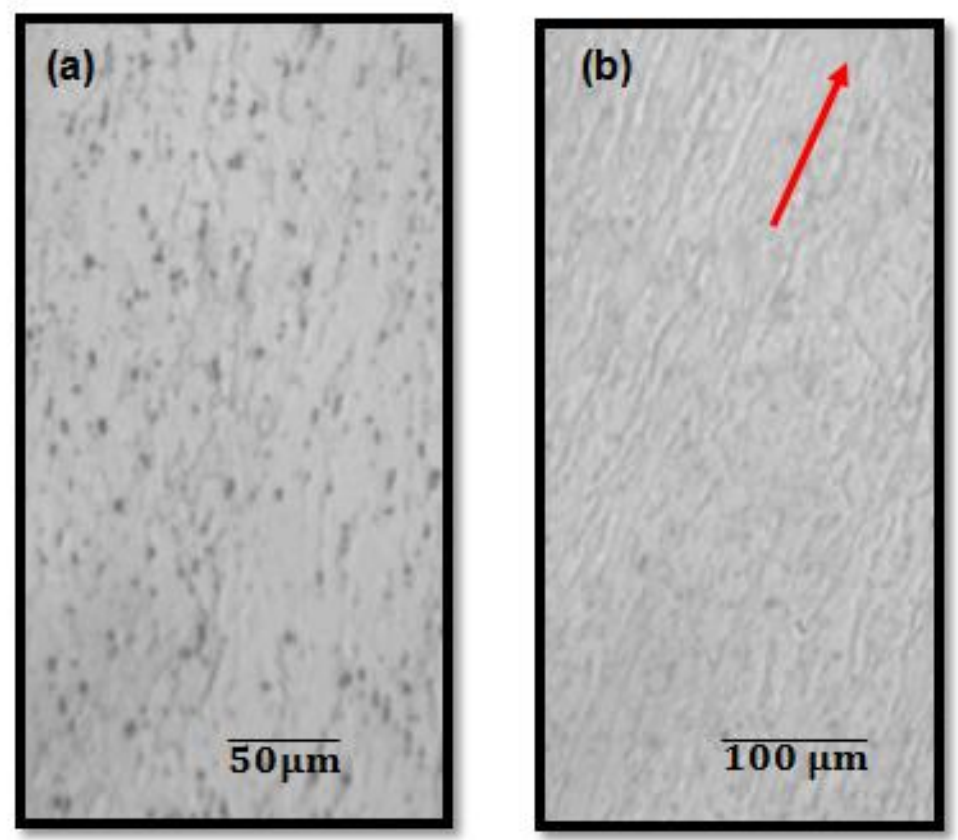

Figura 47. Micrografias da secção normal da liga AA 1050 - pós PCE - rota Bc pós envelhecimento (250 ำ -30 minutos): (a) aumento 50X; (b) aumento 100X, com a indicação do sentido de extrusão.
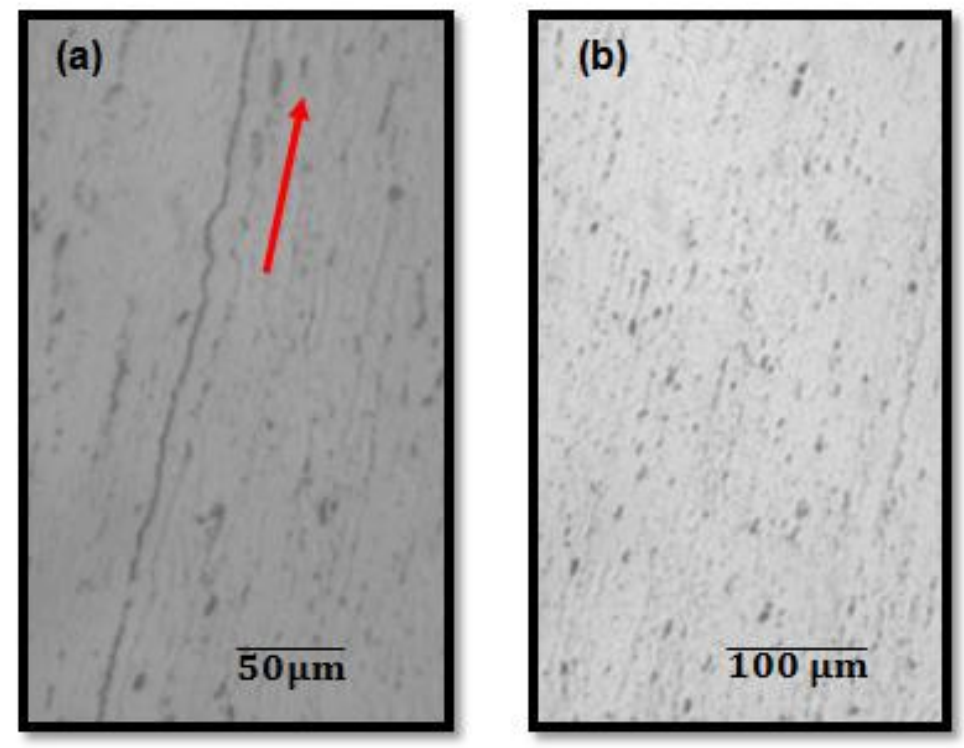

Figura 48. Micrografias da secção transversal da liga AA 1050 - pós PCE - rota Bc - pós envelhecimento (250 ำ - 30 minutos): (a) aumento 50X, com a indicação do sentido de extrusão ; (b) aumento 100X. 

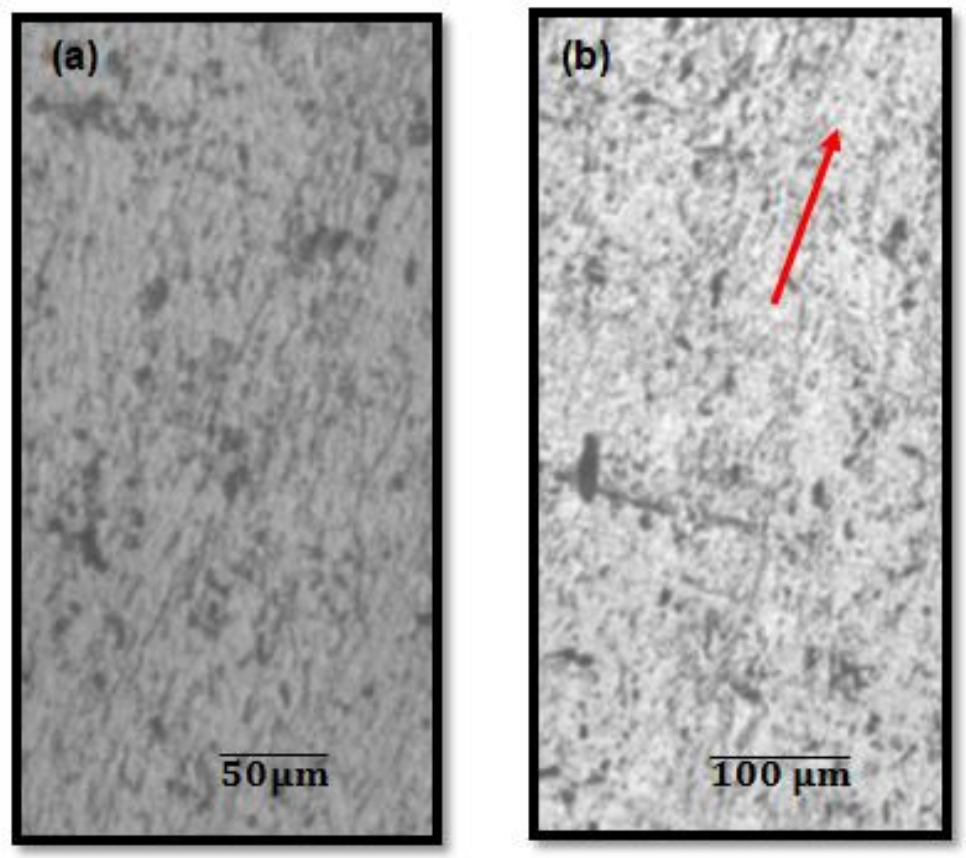

Figura 49. Micrografias da secção normal da liga AA 1050 - pós PCE - rota Bc pós envelhecimento (250 ำ - 60 minutos): (a) aumento 50X; (b) aumento 100X, com a indicação do sentido de extrusão.
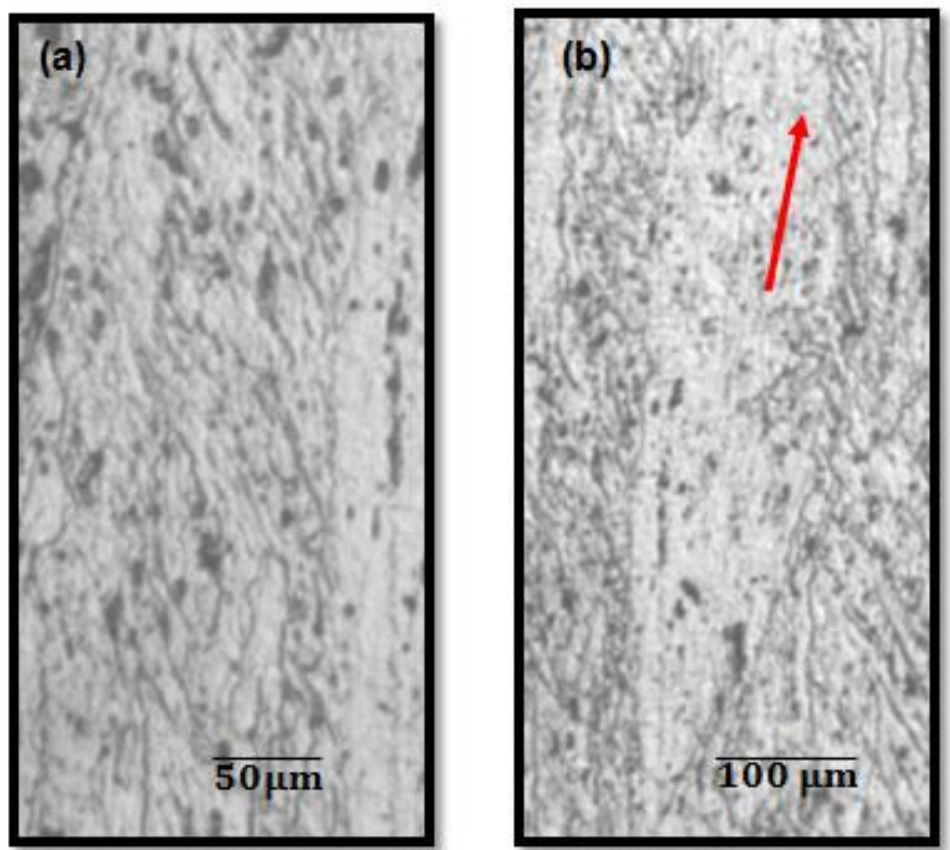

Figura 50. Micrografias da secção longitudinal da liga AA 1050 - pós PCE - rota Bc - pós envelhecimento (250 ำ - 60 minutos): (a) aumento 50X; (b) aumento 100X, com a indicação do sentido de extrusão. 

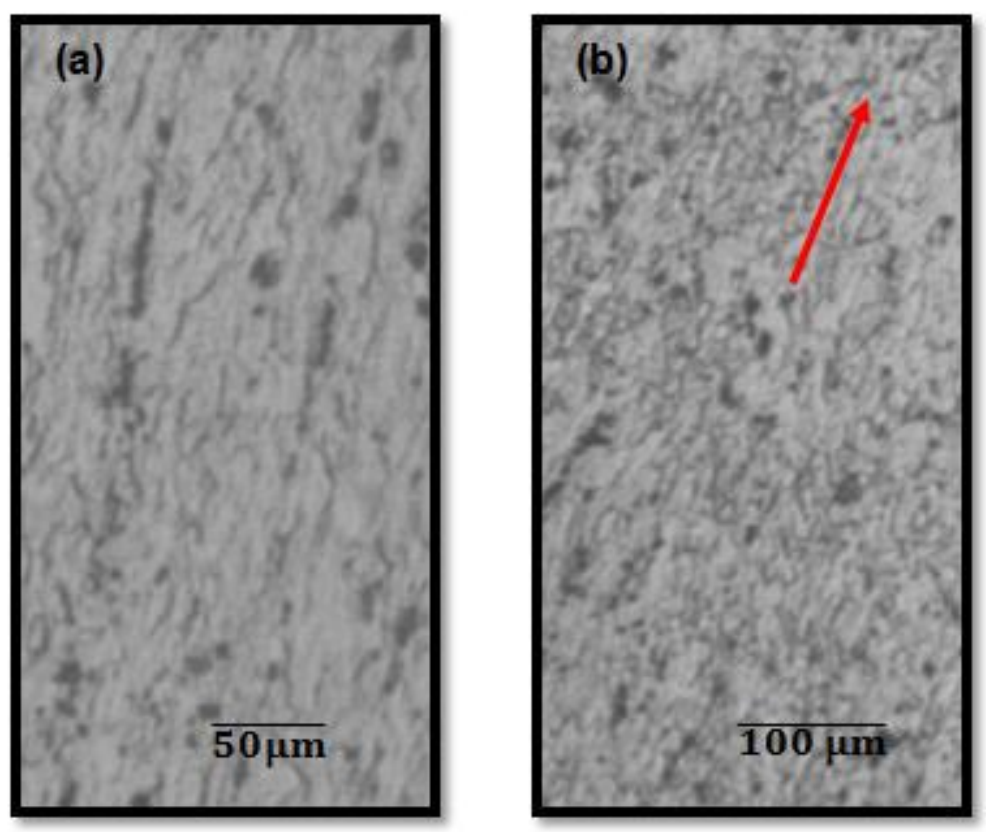

Figura 51. Micrografias da secção normal da liga AA 1050 - pós PCE - rota Bc pós envelhecimento (250 $\mathrm{C}-90$ minutos): (a) aumento 50X; (b) aumento 100X, com a indicação do sentido de extrusão.
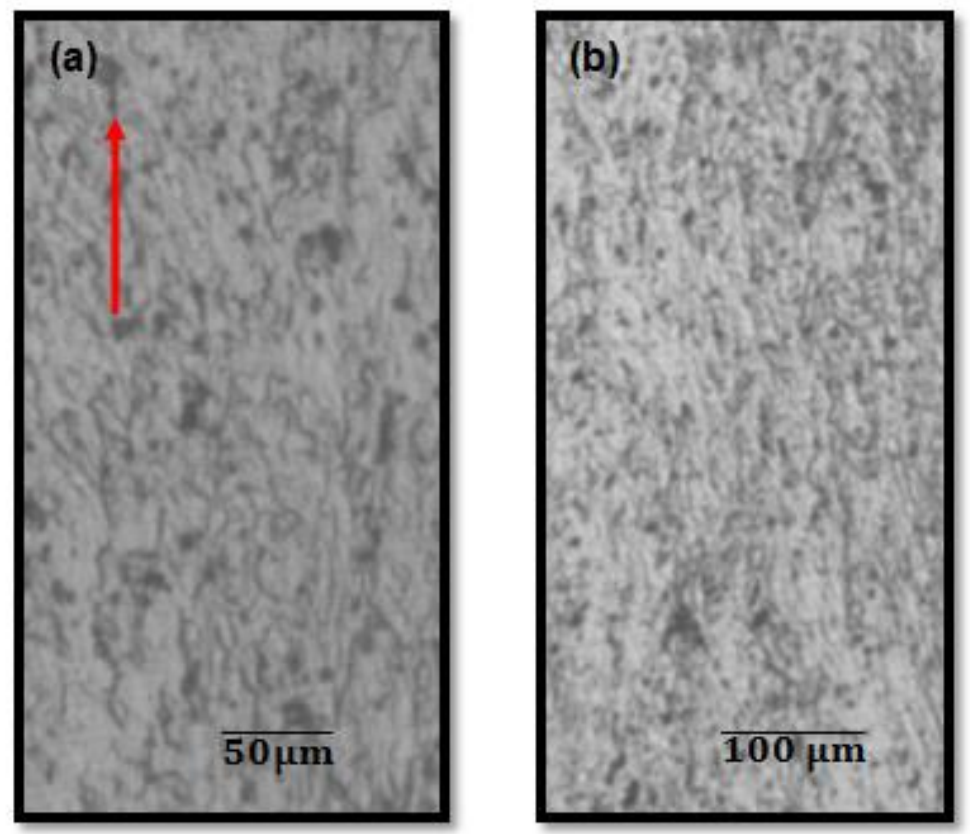

Figura 52. Micrografias da secção longitudinal da liga AA 1050 - pós PCE - rota Bc - pós envelhecimento (250 ํ C - 90 minutos): (a) aumento 50X, com a indicação do sentido de extrusão; (b) aumento 100X. 

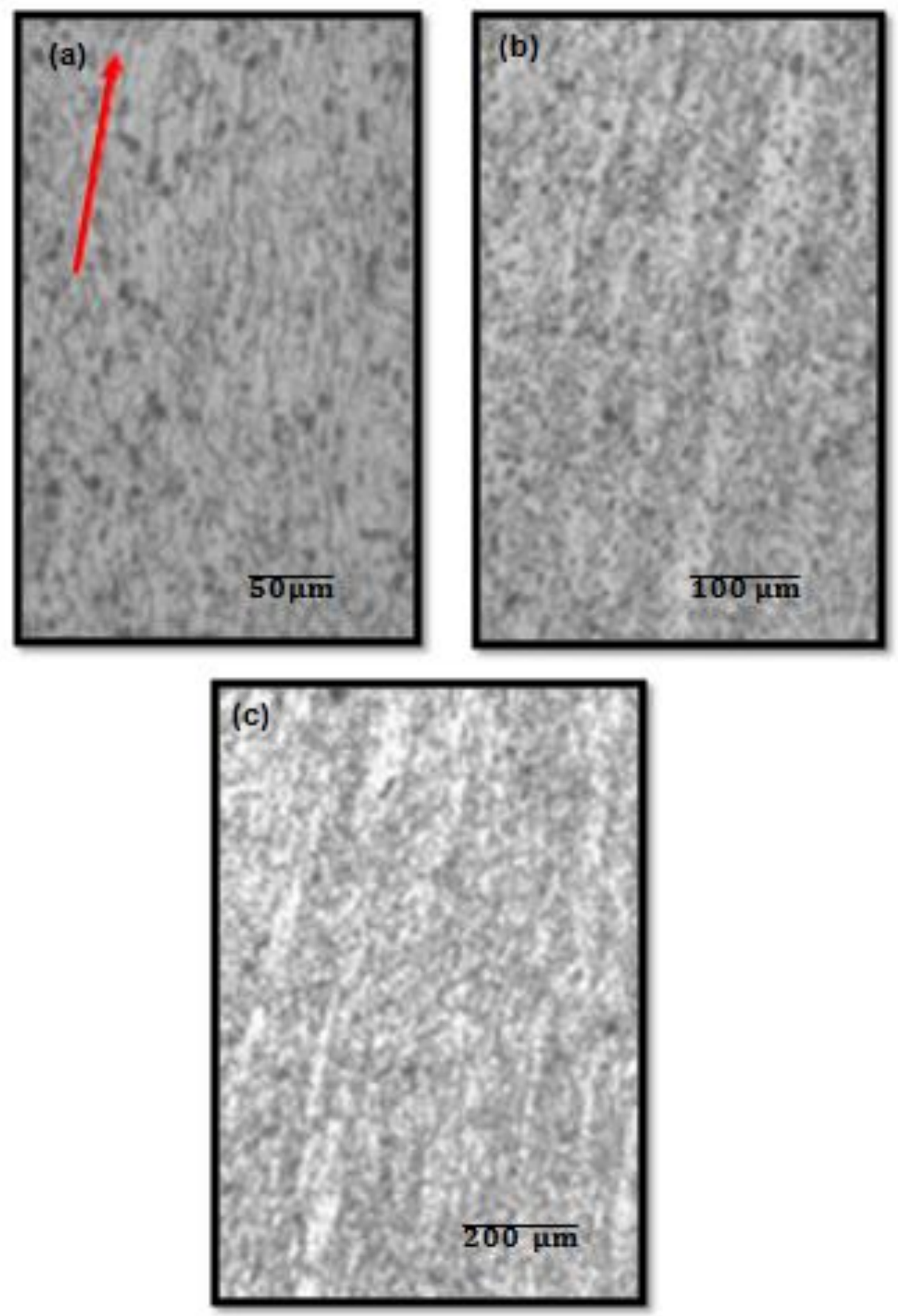

Figura 53. Micrografias da secção normal da liga AA 1050 - pós PCE - rota Bc - pós envelhecimento (250 ำ - 120 minutos): (a) aumento 50X, com a indicação do sentido de extrusão; (b) aumento 100X; (c) aumento 200X. 

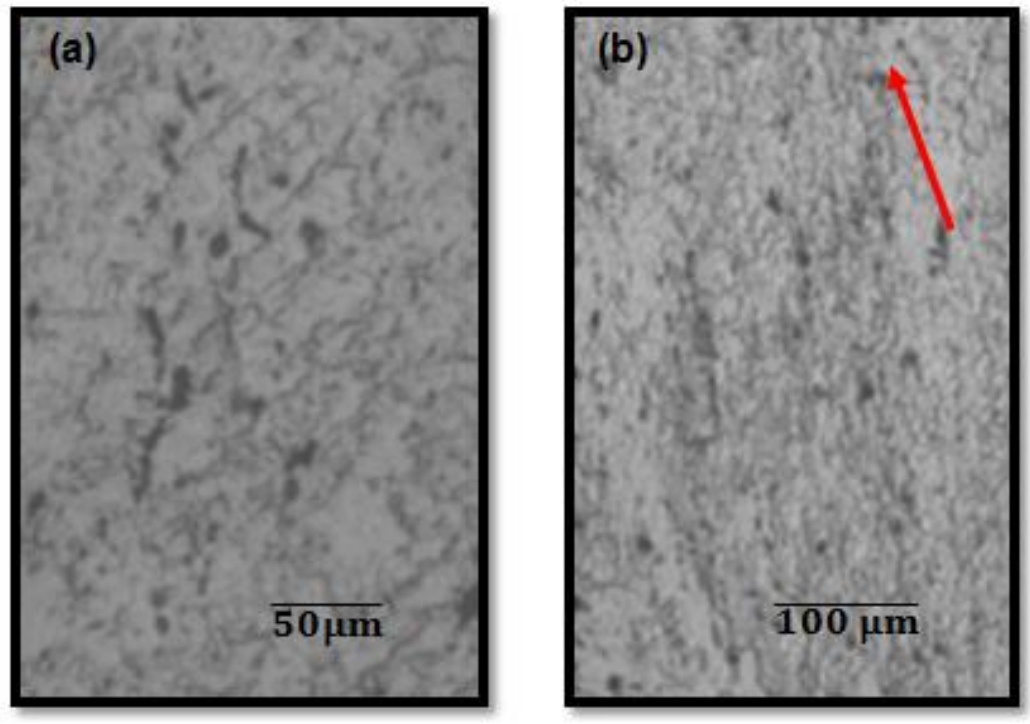

Figura 54. Micrografias da secção longitudinal da liga AA 1050 - pós PCE - rota $\mathrm{Bc}$ - pós envelhecimento (250 ำ -120 minutos): (a) aumento 50X; (b) aumento 100X, com a indicação do sentido de extrusão.
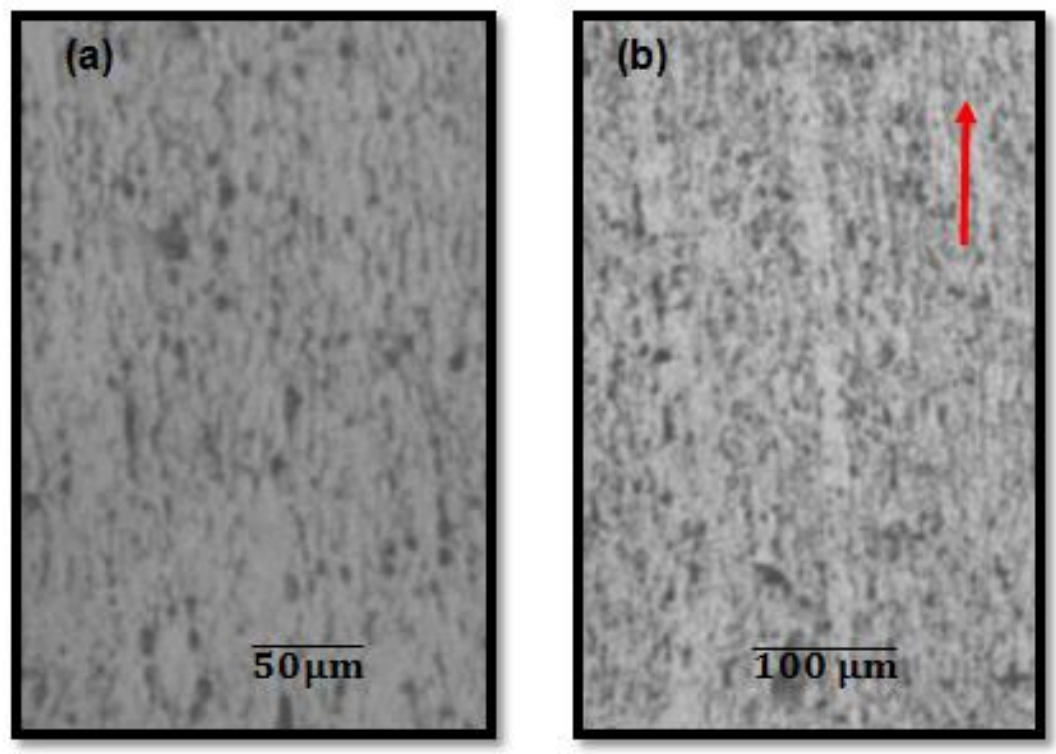

Figura 55. Micrografias da secção transversal da liga AA 1050 - pós PCE - rota $\mathrm{Bc}$ - pós envelhecimento (250 ํㅡ -120 minutos): (a) aumento 50X; (b) aumento 100X, com a indicação do sentido de extrusão. 
A análise de todas as micrografias ópticas, tanto dos corpos de prova que percorreram a rota $\mathrm{A}$, como os que cumpriram a rota $\mathrm{Bc}$, assim como as obtidas pelo plano de visão normal quanto o longitudinal e o transversal, ou ainda as de aumento 50X, 100X e 200X, indicou bandas de deformação. Estas bandas apresentaram-se mais largas e em menor número para as micrografias dos corpos de prova que percorreram a rota $A$. $E$ as que representaram os corpos de prova submetidos à rota $\mathrm{Bc}$ indicaram maior quantidade de bandas mais finais sempre no sentido da extrusão, sobretudo após o envelhecimento, porque, antes dele as citadas bandas de deformação, não obstante no mesmo sentido, o da

extrusão, apresentaram-se mais largas. Concluiu-se assim, que somente resultados advindos do MET - Microscópio Eletrônico de Transmissão, poderiam assertivamente mostrar os contornos de grão e as deformações microestruturas impostas ao material, em todas as situações já citadas.

\subsubsection{Microscopia Eletrônica de Transmissão (MET)}

\subsection{Micrografias das Amostras Prensadas pela rota A}

Em uma análise comparativa das micrografias eletrônicas dos corpos de prova que percorreram a rota $A$, antes e depois do envelhecimento, percebeu-se refinamento maior dos grãos após o envelhecimento, possivelmente por causa do alívio de tensão fornecido pelo tratamento térmico sobre as deformações sofridas pelo material que havia saído da prensagem por canais equiangulares. Em outra comparação, ficaram perceptíveis tamanhos de grão menores apresentados pelas micrografias dos corpos de prova que percorreram a rota $\mathrm{Bc}$, Figura 55 , que os apresentados pelas micrografias do material submetido ao percurso da rota $\mathrm{A}$, conforme Figura 54 . 

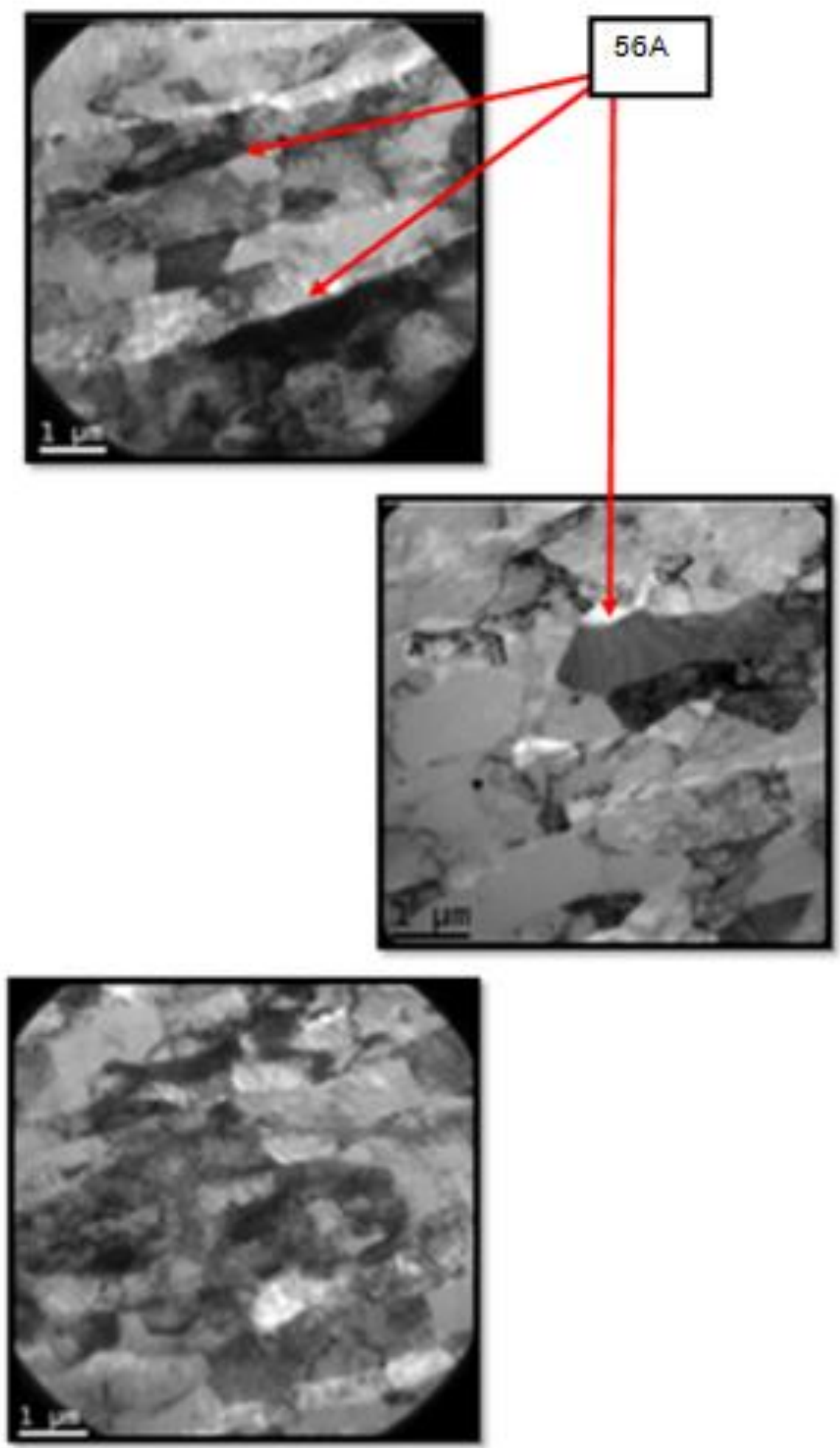

Figura 56. Micrografias eletrônicas de transmissão da secção transversal da liga AA 1050 - pós PCE - rota A - pós envelhecimento ( $250 \stackrel{\circ}{\circ}-120$ minutos). Figura 56A. Ângulo reto entre dois planos de cisalhamento. 
5.2.4.2 Micrografias das Amostras Prensadas pela rota Bc

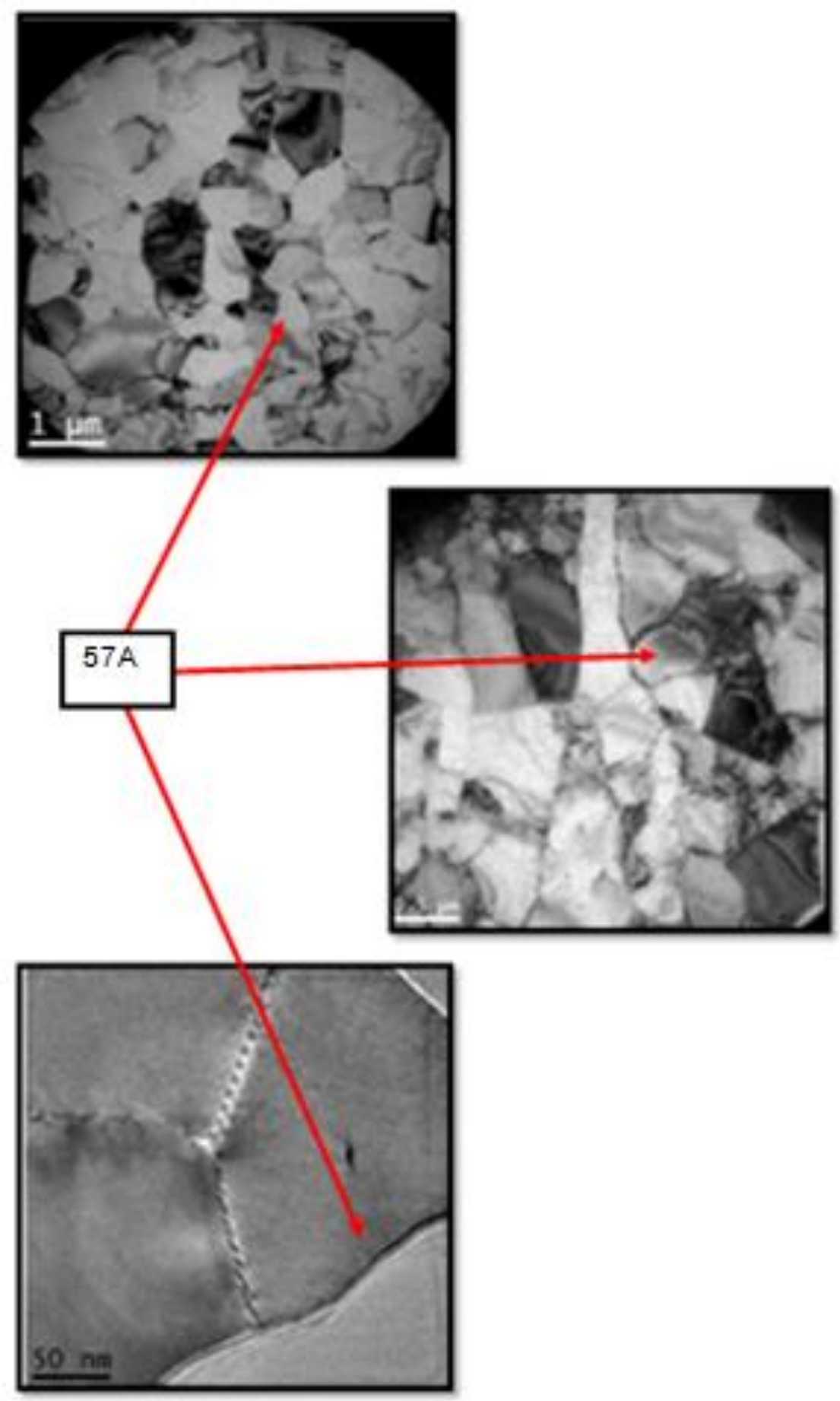

Figura 57. Micrografias eletrônicas de transmissão da secção transversal da liga AA 1050 - pós PCE - rota Bc - pós envelhecimento (250 ํ -120 minutos). Figura 57A. Subgrãos e discordância intrínseca ao grão. 
Ficou nítido o ângulo reto formado por dois planos de cisalhamento Figura 56A, responsáveis pela deformação plástica intensa sofrida pelo material que percorreu a rota $A$. Esta DPI provocou diminuição tal do tamanho de grão, a ponto de ele não ser perceptível se observado por microscopia óptica. $O$ ultrarrefinamento ficou mais sensível ainda no material submetido à rota $\mathrm{Bc}$, porque a deformação redundante que não apareceu no material da rota $A$, agora aparece nas micrografias dos corpos de prova da rota Bc. Isto é, o número ímpar de passes tem a sua deformação cancelada pela próxima passagem que faz a microestrutura voltar à configuração inicial, o que indica o cisalhamento realizado, não obstante as linhas de deformação não estivessem expressas tanto quanto as do material que sofreu as deformações pelos passes da rota A. Ratificando o que foi exarado na literatura, a diferenciação nas extrusões dos corpos de prova ficou associada ao tamanho de grão apresentado no final dos processos sofridos. Assim, há diferenças nos reticulados da célula cristalina do material ao percorrer uma ou outra rota. Isto porque na rota A não ocorre a retomada da configuração inicial, sempre ocorrida no material que passa pelo percurso Bc a cada quatro passagens. A agudez das deformações foi tal que no conjunto de micrografias da Figura 57 foi possível observar as discordâncias intrínsecas ao grão, formando subgrãos, conforme Figura 57A.

\subsubsection{Determinação da Microdureza Vickers (HV)}

$\mathrm{Na}$ Tabela 13 foram colocados os valores médios com a respectiva tolerância, das medições efetuadas nas amostras que foram submetidas ao processo PCE (4 passes) tanto pela rota $A$ quanto pela rota Bc do material que compõe a liga AA 1050. Após o PCE estas amostras também sofreram os tratamentos térmicos posteriores - envelhecimento $(250 \stackrel{\circ}{\circ})-$, em intervalos de tempo $(\Delta \mathrm{t})$ diferenciados: $0,30,60,90$ e 120 minutos, sendo que $\Delta t=0$ significa o material antes da submissão ao envelhecimento. Os valores médios vieram de uma série de cinco medidas. 
Tabela 13 - Microdureza Vickers (HV) - Liga AA 1050 - pós PCE - (rota A e rota $\mathrm{Bc}-4$ passes) e pós envelhecimento (250 ํㅡ - tempos diversos). Carga de 300 g.

\begin{tabular}{|c|c|c|}
\hline \multicolumn{3}{|c|}{ MICRODUREZA VICKERS (HV) - Carga $\mathbf{3 0 0} \mathbf{~ g}$} \\
\hline \multirow{2}{*}{$\begin{array}{c}\Delta \mathbf{t} \\
\text { (minuto) }\end{array}$} & A & Bota \\
\hline 0 & $43 \pm 1$ & $47 \pm 1$ \\
\hline 30 & $46 \pm 1$ & $44 \pm 2$ \\
\hline 60 & $45 \pm 0$ & $39 \pm 2$ \\
\hline 90 & $43 \pm 1$ & $44 \pm 1$ \\
\hline 120 & $42 \pm 1$ & $41 \pm 1$ \\
\hline
\end{tabular}

Em comparando-se os resultados da Tabela 13, com os da Tabela 11, esta com resultados das amostras recém saídas do processo de prensagem por canais equiangulares, percebeu-se que o material que percorreu a rota $A$ praticamente não sofreu alteração em sua resistência mecânica ao ser submetido ao envelhecimento e manteve o aumento de microdureza adquirido ao longo do processo PCE. Enquanto o material que percorreu a rota Bc sofreu variações mais sensíveis ao longo do envelhecimento. Ficou evidente que mesmo com taxas distintas as amostras que passaram pelas rotas A e Bc ao longo dos períodos de medição da microdureza tiveram os seus valores de microdureza em decaimento o que pode relacionar o tipo de tratamento térmico, em relação a seu tempo, com a diminuição da resistência mecânica do material, ainda que sobre ele tenha sido impostas deformações.

Foram observadas taxas de decaimento de microdureza mais expressivas no material que percorreu a rota $\mathrm{Bc}$, do a aquele que percorreu a rota A, o que pode relacionar as deformações plásticas intensas à taxa de decaimento da microdureza do material ao longo do tempo de determinado tratamento térmico. 


\section{CONCLUSÕES}

6.1 Os mecanismos de prensagem por canais equiangulares (PCE) provocaram as deformações estruturais esperadas tanto na liga AA 3003 , quanto na liga AA 1050, tomada como referência e utilizada para comparação. O acúmulo de deformações impostas ao material das ligas pelos canais equiangulares, sem permitir que a secção transversal da amostra se deformasse, provocou deformações plásticas intensas (DPI) aos grãos das ligas, de tal modo que o seu refino associou-se diretamente ao aumento da resistência mecânica dos materiais estudados, como mostraram os resultados registrados na Figura 16, Tabela 05 e Tabela 11, da pesquisa.

6.2 O maior número de passes, tanto no material da liga AA 3003 quanto do material da liga AA 1050, diminuiu o tamanho médio de seus grãos a níveis submicrométricos e aumentou suas propriedades mecânicas de resistência e tenacidade, conforme indicado pela determinação do diâmetro médio do tamanho de grão, Tabela 04 e pelos ensaios de microdureza Vickers realizados, Tabela 05 e Tabela 11.

6.3 Fixado o mesmo número de passes, a indicação do valor médio de microdureza Vickers é menor para o material da amostra que percorre a rota A, quando comparada com o material da amostra que percorre a rota Bc. Esta indicação pode apontar a rota $\mathrm{Bc}$ como a preferencial para atingir os objetivos propostos na pesquisa tanto para o material da liga AA 3003, quanto para 0 material da liga AA 1050. E isto pode corroborar com o que a literatura registrou em relação à preferência de rotas, agora com a inclusão das ligas Al-Mn, cujo comportamento foi confirmado pela atual pesquisa pelos resultados registrados na Tabela 03, 04 e 05.

6.4 $O$ recozimento ( $500{ }^{\circ} \mathrm{C}-1,0 \mathrm{~h}$ ), aplicado ao material da liga $\mathrm{AA}$ 3003 , tanto para as amostras que percorreram a rota $A$, quanto para as que percorreram a rota $\mathrm{Bc}$, mostrou-se eficaz para a recristalização completa do material, conforme resultados apresentados pelas Figuras 18 a 24. O recozimento 
pode ter aliviado as tensões residuais do processo de prensagem, propiciando a recristalização completa do material.

6.5 Em razão dos modos diferenciados de deformações sofridas pelas ligas nas rotas $\mathrm{A}$ e $\mathrm{Bc}$, percebeu-se menor tamanho médio de grão para um mesmo número de passes na rota Bc. Como a diminuição do tamanho médio de grão ficou associado ao aumento da resistência mecânica do material, pode-se ter confirmado a maior eficiência da rota Bc para obtenção de melhores resultados, com a mesmo oferta de esforços oferecidos, conforme indica a comparação da Tabela 04.

6.6 A distinção das rotas apresentaram diferentes planos de cisalhamento devidos às desiguais formas de deformações sofridas pelo material. Isto pode ter feito variar as distorções microscópicas dos grãos individuais e sua capacidade de desenvolver uma microestrutura de grãos apuradamente refinados, equiaxiais e homogêneos.

6.7 Em relação à liga $\mathrm{AA} 3003$, tanto o material que, ao ser submetido ao PCE, percorreu a rota $A$, quanto o que cumpriu a rota $\mathrm{Bc}$, apresentaram aumento em sua condutividade elétrica em relação ao material de início dos procedimento, o como recebido. A diferença entre os percentuais, 13\% e $14,7 \%$, rotas A e Bc, respectivamente, pode corroborar com a percepção da relação direta entre a intensidade de deformação sofrida e a condutividade elétrica, o que não ocorreu com o material da liga AA 1050, que sofreu variação negativa no valor da condutividade elétrica, possivelmente devido ao intenso encruamento do material puro, conforme Tabela 06. 
Referências Bibliográficas

1) BOWEN, J.R., GHOliniA, A., ROBERTS, S.M., PRANGNEL, P.B., "Analysis of the billet deformation behavior in equal channel angular extrusion". Materials Science and Engineering A, vol. A287, pp. 87-99, 2000.

2) BRODOVA I.G., SHIRINKINA I.G., ANTONOVA O.A., SHOROKHOV E.V., ZHGILEV I.I. "Formation of a submicrocrystalline structure upon dynamic deformation of aluminum alloys", Materials Science and Engineering A 503, 103-105, 2009.

3) BURGER, G.B. et alli - "Microstructural Control of Aluminum Sheet Used in Automotive Applications.", Materials Characterization, v.35, p.23-39, 1995.

4) CAI, M., FIELD, D.P., LORIMER, G.W. "A systematic comparison of static and dynamic ageing of two Al-Mg-Si alloys. Mat. Sci. Eng.", v. A373, p. 65 - 71, 2004.

5) CHEN Y.J., CHAI Y.C., ROVEN H.J., GIREESH S.S., YU Y.D., HJELEN $\mathrm{J}$., "Microstructure and mechanical properties of Al-xMg alloys processed by room temperature ECAP", Materials Science and Engineering A 545 , 139- 147, 2012.

6) COLE, G.S. \& SHERMAN, A.M. - "Lightweight Materials for Automotive Applications" - Materials Characterization, 1995, v.35, p.3-9.

7) DHAL A., S.K. PANIGRAHI S.K., M.S. SHUNMUGAM, M.S. "Insight into the microstructural evolution during cryo-severe plastic 
deformation and post-deformation annealing of aluminum and its alloys" Journal of Alloys and Compounds, v.726, pp.1205 - 1219, 2017

8) EEIMVR - UFF - Escola de Engenharia Industrial Metalúrgica de Volta Redonda - Universidade Federal Fluminense, Alumínio e suas Ligas, 2009.

9) FERRASSE S., SEGAL V. M., HARTWIG K. T., GOFORTH R. E. "Microstructure and properties of copper and aluminum alloy 3003 heavily worked by equal channel angular extrusion", Metallurgical and Materials Transactions A, Volume 28a, 1047- 1057, April 1997.

10)GAO N., STARINK M.J., LANGDON T. G. "Using differential scanning calorimetry as an analytical tool for ultrafine-grained metals processed by severe plastic deformation", Materials Science and Technology 25, 687-698, 2009.

11) GLEITER, H.“Nanocrystalline materials“. Prog. Mater. Sci. 33, $223-$ 330, 1989.

12) GOMES, M. R, BRESCIANI FILHO, E. "Propriedades e Usos de Metais Não ferrosos”, ABM, São Paulo, 1987.

13) GUERRA, M. C. L., "Caracterização Elétrica e Mecânica da Liga de Alumínio AA 1050, Com Estrutura Ultrafina Processada Pela Técnica de Deformação Plástica Intensa (DPI)" - Dissertação de Mestrado - UPM, 2015.

14) GUINIER, A. "Heterogeneities in Solid Solution, Solid State Physics", v.9, July, p.346-351, 1959.

15) HATCH, J.E. Aluminum: "Properties and Physical Metallurgy", ASM, Metals Park, USA, 1990. 
16) HORITA Z., TAKAYOSHI F., NEMOTO M., LANGDON T.G. "EqualChannel Angular Pressing of Commercial Aluminum Alloys: Grain Refinement, Thermal Stability and Tensile Properties", Metallurgical and Materials Transactions A, volume 31a, 691-701, March 2000.

17) HORITA Z., FUJINAMI T., LANGDON T. G. "The potential for scaling ECAP: effect of sample size on grain refinement and mechanical properties", Materials Science and Engineering A318, 34-41, 2001.

18) ITO, Y., HORITA Z. "Microstructural evolution in pure aluminum processed by highpressure torsion", Materials Science and Engineering: A, 503, pp. 32-36, 2009

19) KIM, H.S., ESTRIN, Y., "Microstructural modelling of equal channel angular pressing for producing ultrafine grained materials". Materials Science and Engineering A, 2005.

20) $\mathrm{KOCH}$, C.C. "Optimization of strength and ductility in nanocrystalline and ultrafine grained metals". Scripta Mater. 49, 657 $-662,2003$.

21) KORCHEF A., NJAH N., KOLSI A. W. "Microstructure investigation of equal channel angular pressed aluminium by X-ray diffraction and scanning electron microscopy", Cryst. Res. Technol. 44, No. 1, $106-110,2009$.

22) LANGDON, T.G., FURUKAWA, M., NEMOTO, M., HORITA, Z; JOM 52, "Factors affecting grain refinement in equal-channel angular pressing" 4, 30-33, 2000. 
23) LAPOVOK R., MCKENZIE P. W. J., THOMSON P. F., SEMIATIN S. L. "Processing and properties of ultrafine-grain aluminum alloy 5005 sheet”, Materials Science and Engineering , 42:1649 -1659, 2007.

24) LUCAS, G. - "Aluminum Structural Applications" - Advanced Materials \& Processes, n.5, p.29-3, 1996.

25) MEDEIROS, N. “Análises teórica e numérica do processo de prensagem em canais equiangulares". Tese (Doutorado em Engenharia Metalúrgica), Universidade Federal Fluminense, 217f, Volta Redonda, 2008.

26) METALS HANDBOOK, ASM, 9 th printing, v.14, "Metals Park", p.317319, Ohio, 1988.

27) MARKUSHEV, M.V. YU, M. MURASHKIN, M. "Structure and mechanical properties of commercial Al-Mg 1560 alloy after equalchannel angular extrusion and annealing". Mat. Sci. Eng., v. A367, p. $234-242,2004$.

28) McALISTER A.J., MURRAY J.L., 1987. 438. Bulletin of Alloy Phase Diagrams Vol. 8 No. 5, 1987.

29) MORRIS, D.G. "Mechanical Behaviour of Nanostructured Materials" (Trans Tech, Uetikon-Zürich, 1998).

30) MURRAY, J.L. Phase "Diagrams of Binary Magnesium Alloys", ASM International, p. 17, Ohio, 1988.

31)NAGASEKHAR, A.V.; TICK-HON, Y.; SEOW, H.P. "Deformation behavior and strain homogeneity in equal channel angular extrusion/pressing". Journal of Materials Processing Technology, v. 192-193, p. 449-452, 2007. 
32)POGGIALI, F.S.J. “Determinação da influência do refino de grão por ECAP no comportamento em compressão do magnésio comercialmente puro", Tese de D.Sc (Engenharia Metalúrgica), Universidade Federal de Minas Gerais, 2015.

33) POPOV, V.V., POPOVA, E.N. et al. "Nanostructuring Nb by various techniques of severe plastic deformation" Materials Science and Engineering A, v.539 p. 22-29, 2012.

34) SABIROV I., YU, M. MURASHKIN, R.Z. VALIEV. “Nanostructured aluminium alloys produced by severe plastic deformation: New horizons in development", Materials Science \& Engineering A, v.560, p.1-24, 2013.

35) SEGAL, V.M., REZNIKOV, V.I., DROBYSHEVSKIY, A.E. \& KOPYLOV,V.I. "Plastic working of metals by simple shear". Russian Metall. 1, 99-105, 1981.

36) SEGAL, V. M., REZNIKOV V. I., DROBYSHEVSKIY A. E. , KOPYLOV V. I. "Russian Metall”, 1, 115-123, 1981.

37) SEGAL, V. M.: Materials Science and Engineering, A197, 157-164, 1995.

38) SEGAL, V. M., "Engineering and commercialization of equal channel angular extrusion (ECAE)". Materials Science and Engineering A, vol. 386, pp. 269-276, 2004.

39) SILVA, S. L. V., "Caracterização da liga de níquel 600 com estrutura ultrafina processada pela técnica de deformação plástica intensa (dpi)", dissertação de mestrado, IPEN-USP, 2013. 
40) UTSUNOMIYA H., HATSUDA K., SAKAI T., SAITO Y. "Continuous grain refinement of aluminum strip by conshearing", Materials Science and Engineering A $372,199-206,2004$.

41) VALIEV R.Z., KRASILNIKOV N.A., TSENEV N. K. "Plastic deformation of alloys with submicron-grained structure". Materials Science and Engineering, A137, 35-40, 1991.

42) VALIEV, R.Z., "Nanostructuring of metals by severe plastic deformation for advanced properties". Nature Materials, v.3, pp.511516, 2004.

43) VALIEV R.Z., ESTRIN Y., HORITA Z., LANGDON T.G., ZEHETBAUER M.J, ZHU Y.T. JOM, "Producing bulk ultrafine-grained materials by severe plastic deformation", 58 (4), 33-39, 2006.

44) VALIEV R. Z. and LANGDON T. G. "Progress in materials science" 2006, 51, 881-981.

45) VAN HORN, K.R. - "Aluminum", v.1, ASM, 1st printing, Metals Park, Ohio, p.324-327, 1967.

46) WANG, Y.Y. SUN, P.L. KAO, P.W. CHANG, C.P. "Effect of deformation temperature on the microstructure developed in commercial purity aluminum processed by equal channel angular extrusion". Scripta Materialia, v. 50, p. 613 - 617, 2004.

47) WEERTMAN, J.R. "Mechanical properties of nanocrystalline materials", Mater. Sci. Eng. A 166, 161-171 1993.

48) ZHERNAKOV,V. S. et al. A numerical modelling and investigations of flow stress and grain refinement during equal-channel angular pressing. Scripta Mater. 44, 1765-1769, 2001.

49) YAMAGUSHI, D., HORITA, Z., FUJINAMI, T., NEMOTO, M., LANGDON, T.G. "Factors affecting grain refinement in equal- 
channel angular pressing". Mat. Sci. Forum, v. 331-337, p. $607-612$ , 2000.

50) YU, C.Y., SUN, P.L., KAO, P.W., CHANG C.P. "Evolution of microstructure during annealing of a severely deformed aluminum". Mat. Sci. and Eng. v. A366, p. 310 - 317, 2004. 


\section{INSTITUTO DE PESQUISAS ENERGÉTICAS E NUCLEARES}

Diretoria de Pesquisa, Desenvolvimento e Ensino

Av. Prof. Lineu Prestes, 2242 - Cidade Universitária CEP: 05508-000

Fone/Fax(0XX11) 3133-8908

SÃO PAULO - São Paulo - Brasil

http://www.ipen.br

O IPEN é uma Autarquia vinculada à Secretaria de Desenvolvimento, associada à Universidade de São Paulo e gerida técnica e administrativamente pela

Comissão Nacional de Energia Nuclear, órgão do

Ministério da Ciência, Tecnologia, Inovações e Comunicações. 